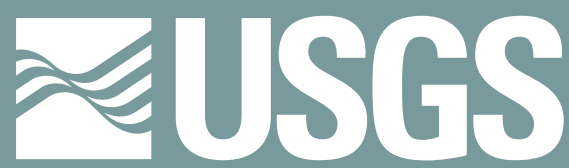

science for a changing world

\title{
Structural Geology of Western Part of \\ Lemhi Range, East-Central Idaho
}

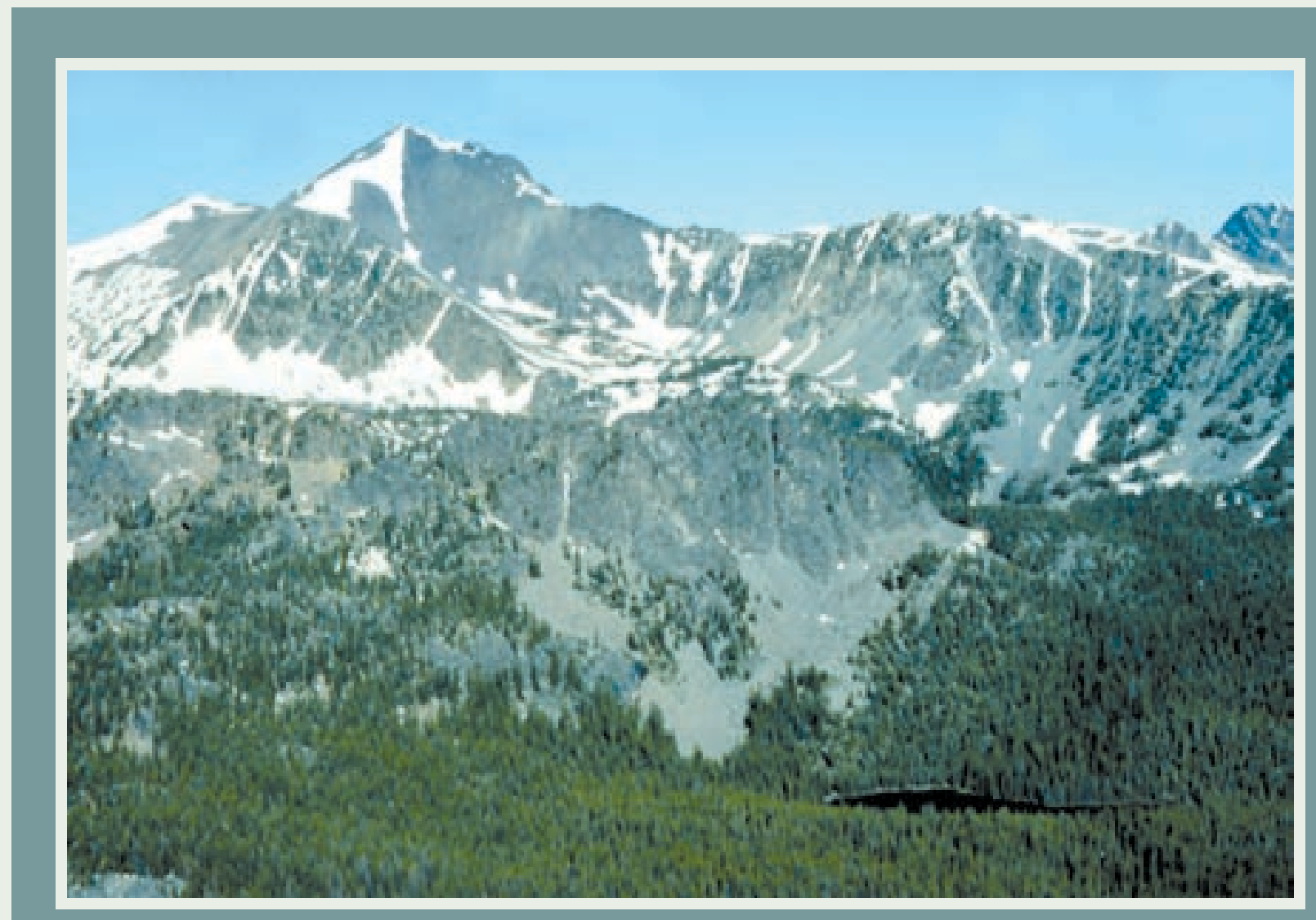

U.S. Geological Survey Professional Paper 1659 
Cover. Looking southwest toward Lem Peak, Lemhi Range. 


\title{
Structural Geology of Western Part of Lemhi Range, East-Central Idaho
}

\author{
By Russell G. Tysdal
}

U.S. Geological Survey Professional Paper 1659

A reconstruction of the Poison Creek anticline, a very large amplitude fold now broken by normal faults; fold is in the hangingwall of a major thrust fault

U.S. Department of the Interior

U.S. Geological Survey 


\section{U.S. Department of the Interior}

Gale A. Norton, Secretary

\section{U.S. Geological Survey}

Charles G. Groat, Director

Version 1.02002

For sale by U.S. Geological Survey, Information Services

Box 25286, Federal Center

Denver, C0 80225

This publication is also available online at: http://geology.cr.usgs.gov/pub/ppapers/p1659/

Any use of trade, product, or firm names in this publication is for descriptive purposes only and

does not imply endorsement by the U.S. Government

ISBN: 0-607-98411-2 


\section{Contents}

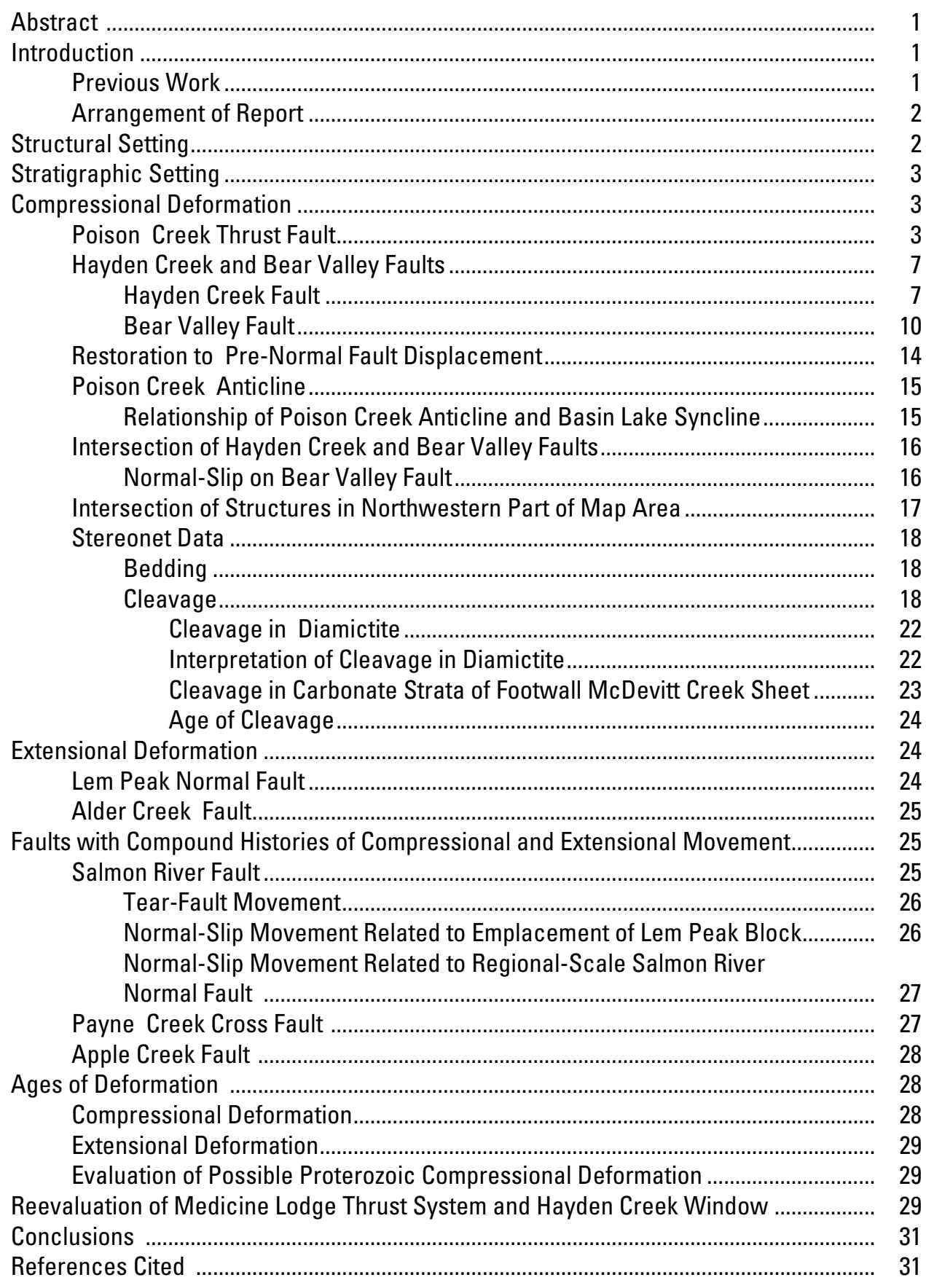




\section{Figures}

1. Index map of east-central Idaho, showing prominent geographic features.............. 2

2. Index to mapping in study area ................................................................................... 2

3. Tectonic map showing major faults, subsheets, and blocks in study area ................ 5

4. Geologic map of study area ................................................................................. 6

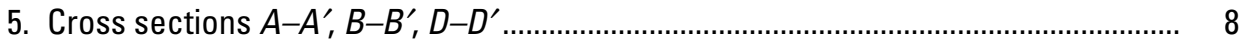

6. Cross sections restored to pre-normal-slip displacement ......................................... 10

7. Cross section showing large fold determined from reconstructed cross sections .................................................................................................. 12

8. Map and cross section ( $C-C)$ of Hayden Creek fault showing thrust and normal displacement............................................................................................ 13

9. Diagrammatic sketch showing fold pattern in northwestern part of study area ........ 17

10. Stereonet diagrams of bedding ..................................................................... 19

11. Stereonet diagrams of cleavage ............................................................................. 20

\section{Table}

1. Description and thickness of rock units within or directly adjacent to study area. 


\title{
Structural Geology of Western Part of Lemhi Range, East-Central Idaho
}

\author{
ByRussell G. Tysdal
}

\section{Abstract}

The large Poison Creek anticline, now broken by normal faults, is the major structure in the western part of the Lemhi Range. The fold resulted from late Mesozoic compressional deformation in the hinterland of the Cordilleran thrust belt in central Idaho. Bedrock of the study area is mainly Mesoproterozoic strata that are part of a thrust sheet floored by the Poison Creek fault, a major thrust fault whose trace extends northwest across the northern part of the study area. The thrust fault displaced the Proterozoic rocks over lower Paleozoic formations composed of carbonate and quartzite. In the southern part of the study area, the easterly trending Lem Peak normal fault has vertical displacement of several thousand meters and may cut the Poison Creek thrust fault at depth. Between the trace of the Lem Peak normal fault and the Poison Creek thrust fault lie the Hayden Creek and Bear Valley faults, which in their present configuration show normal displacement. The Hayden Creek fault, however, has a demonstrable thrust displacement prior to normal displacement. Both it and the Bear Valley fault may have formed originally as subsidiary thrusts of the Poison Creek thrust fault, generated during rupture of tight folds within the Poison Creek thrust sheet. Removal of the normal component of slip on the Hayden Creek and Bear Valley faults, restoring rocks to about their pre-normal-slip positions, reveals the original geometry of the eastern part of the large Poison Creek anticline above the Poison Creek thrust fault.

A single regionally extensive thrust sheet, the Medicine Lodge thrust system, previously was interpreted as the major structure of the region. Within the southeastern part of the present study area, a window was stated to exist in the vicinity of Hayden Creek and to expose rocks of the subthrust Mesoproterozoic Yellowjacket Formation. My mapping leads me to conclude that neither the Medicine Lodge thrust plate nor the window exists in this part of the range.

The northwest-trending structural grain of the Lemhi Range is truncated by the north-striking Salmon River fault at the western margin of the study area. The fault is oblique to the structural grain of the range and is interpreted as a tear fault that formed during Mesozoic thrust faulting and folding of rocks of the Poison Creek thrust sheet. The fault served to compartmentalize the style of deformation that took place on opposite sides of it. Rocks east of the Salmon River fault, the main focus of this report, deformed into the major fold and associated subsidiary thrusts of the Poison Creek sheet. Rocks directly west of the Salmon River fault generally display low dips and locally define a shallow-dipping syncline oriented about parallel to the north-trending fault. A segment of the fault subsequently was reactivated as part of the Lem Peak normal fault during downdropping of the Lem Peak block. Later, the entire length of the present Salmon River fault was reactivated as a basin-and-range normal fault that dips steeply to the west.

\section{Introduction}

The study area is in the northern part of the Lemhi Range of central Idaho (fig. 1), a region entirely within the Cordilleran overthrust belt of the Rocky Mountains. Meso- and Neoproterozoic ${ }^{1}$ and Phanerozoic strata are prominent in the central and southern parts of the range, southeast of the study area. Bedrock of the northern part of the range is chiefly Mesoproterozoic rocks, with only local areas of Paleozoic strata preserved. Igneous rocks of the middle Eocene Challis Volcanic Group are widespread to the west and southwest. The volcanic rocks form locally extensive outcrops on the flanks of the northern part of the Lemhi Range, but within the higher parts of the range they are preserved only in small isolated patches.

\section{Previous Work}

The study area (fig. 2) contains some previously unmapped territory, whereas some parts are covered by previously published and unpublished mapping. Much of the area was covered by the thesis areas of Soregaroli (1961) and Tietbohl (1981). The eastern part includes the southwest corner of the Lemhi 15-minute quadrangle mapped by Anderson (1961) and the northwest corner of the Patterson 15-minute quadrangle mapped by Ruppel (1980). A discussion of the geology in the Patterson quadrangle was presented in Ruppel and Lopez (1988). In addition, the study area includes the southernmost part of the Goldbug Ridge 7.5-minute quadrangle (Evans, 1999; K.V. Evans, Falma Moye, and R.F. Hardyman, unpub. mapping, 1996) and the adjacent Poison Peak quadrangle (G.R. Winkler, unpub. mapping, 1996). This report is based on published geologic mapping studies of Tysdal (1996a, 1996b,

\footnotetext{
${ }^{1}$ The terms Middle and Late Proterozoic, respectively, were used for these eras in previous publications by the author. The present usage follows that of the International Union of Geological Sciences (IUGS) subcommittee on Precambrian stratigraphy (Plumb, 1991).
} 


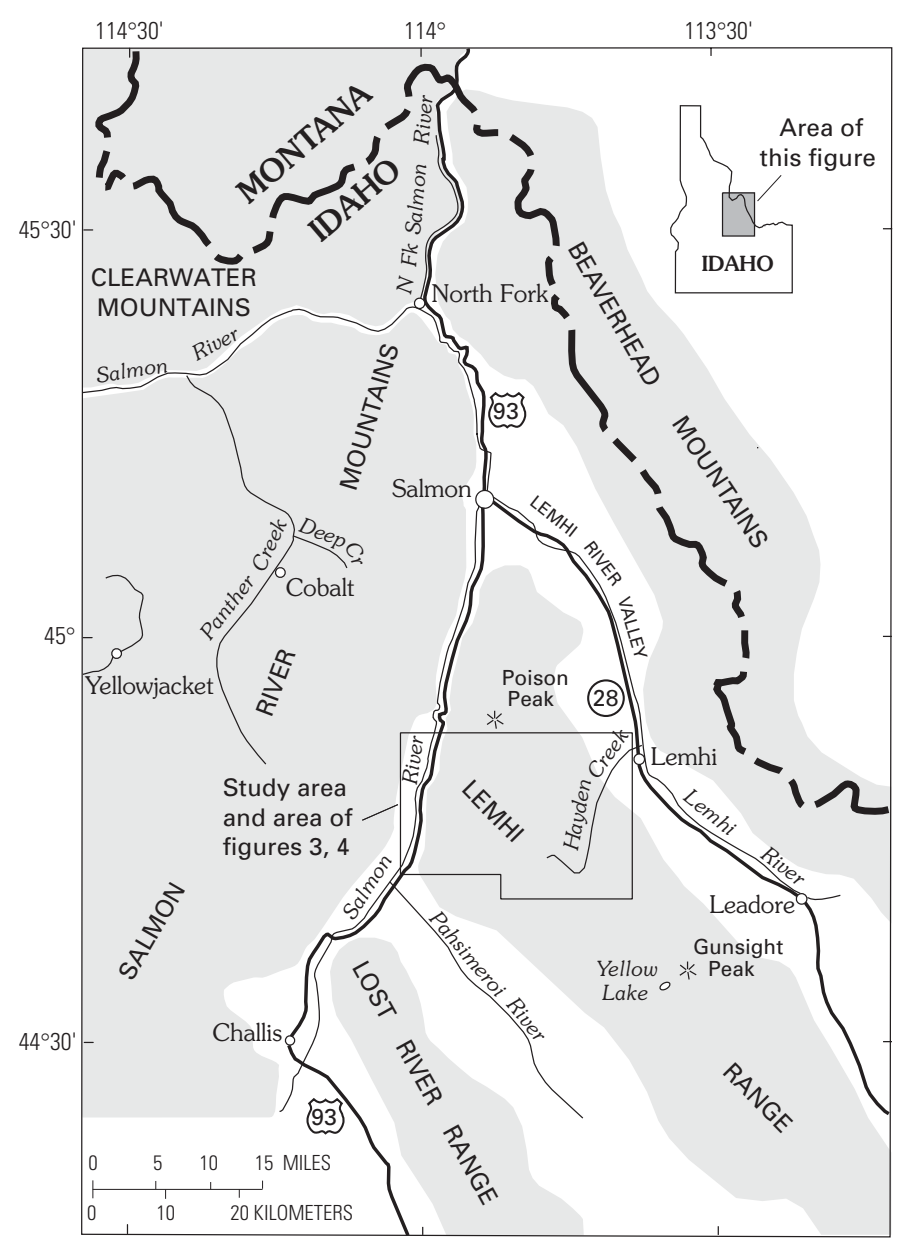

Figure 1. Index map of east-central Idaho, showing prominent geographic features.

1996c) and Tysdal and Moye (1996), as well as local areas of unpublished mapping of Tysdal.

\section{Arrangement of Report}

This report generally discusses compressionally formed structures first, then extensional features. However, removal of later normal-slip movement from several (originally) thrust faults is necessary before discussion of the compressional features is feasible. Hence, the two types of deformation are considered together for several faults within the range. Interpretation of compressional deformation is presented in a section that makes use of stereonet compilations of bedding and cleavage. Extensional faults for which no restoration to pre-slip positions was undertaken are then described. A final part of the report discusses the previously described Medicine Lodge thrust plate and the Hayden Creek window.

\section{Structural Setting}

Central Idaho is part of the hinterland of the thrust belt in the eastern part of the Cordillera of the western United States.

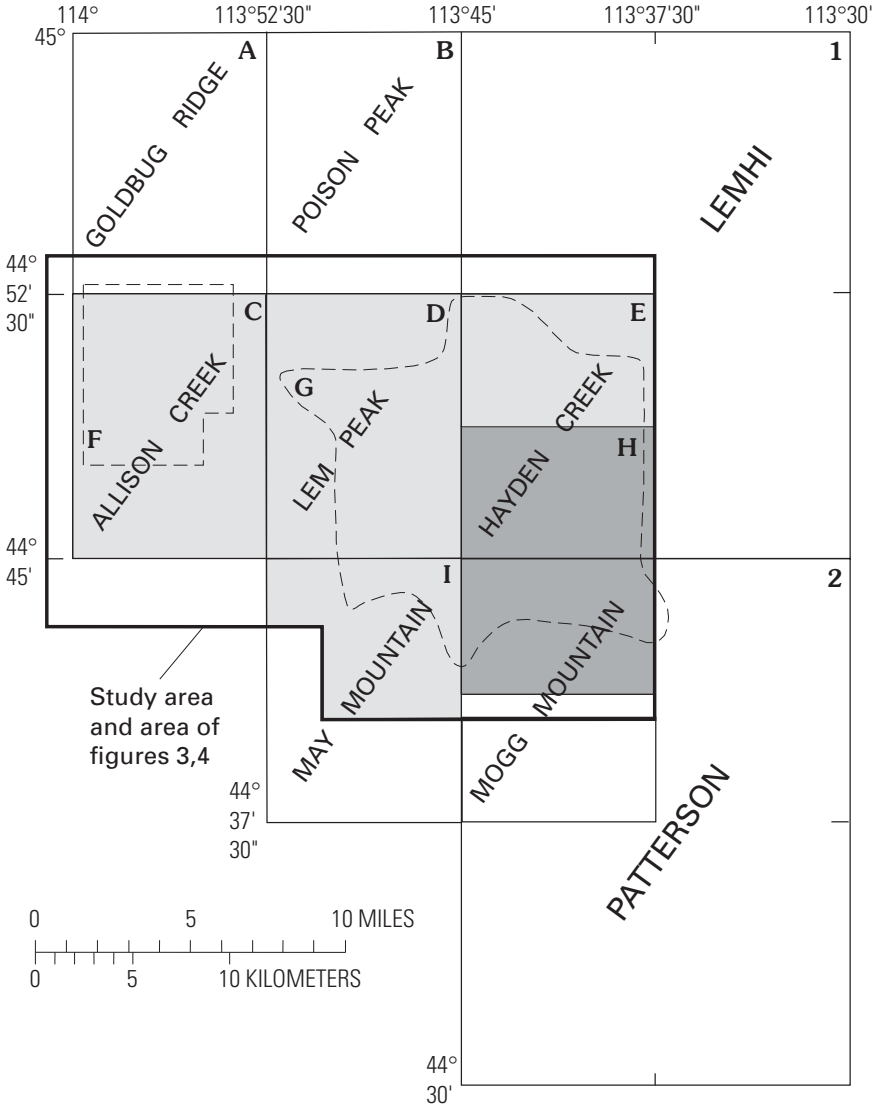

1:24,000 and other geologic maps

\begin{tabular}{|c|c|c|}
\hline A & K.V. Evans, Falma Moye, and R.F. & G Tietbohl (1981) \\
\hline & Hardyman (unpub. mapping, 1996) & H Tysdal (1996a) \\
\hline B & G.R. Winkler (unpub. mapping, 1996) & Tysdal (1996c) \\
\hline $\begin{array}{l}\text { C } \\
\text { D }\end{array}$ & $\begin{array}{l}\text { Tysdal and Moye (1996) } \\
\text { Tysdal (1996b) }\end{array}$ & 1:62,500 geologic maps \\
\hline E & Tysdal (unpub. mapping, 1996-2000) & 1 Anderson (1961) \\
\hline $\bar{F}$ & Soregaroli (1961) & 2 Ruppel (1980) \\
\hline
\end{tabular}

Figure 2. Index to geologic mapping studies in western part of Lemhi Range. Names of 7.5- and 15-minute topographic quadrangles are labeled in figure.

The study area (fig. 1) lies within this region and generally displays lower structural levels and older stratigraphic units than are exposed to the east and south. Along the extent of the Lemhi and Lost River Ranges and the Beaverhead Mountains, preserved Paleozoic strata generally become progressively older from southeast to northwest. In the northern part of the Lemhi Range and the Salmon River Mountains to the west, Paleozoic rocks crop out only in isolated erosional remnants. Upper units of the Mesoproterozoic sequence also have been eroded from broad areas in the northern parts of these mountain ranges.

Proterozoic and Paleozoic strata in the general region of the study area underwent compressional deformation, probably in the Late Cretaceous, creating a series of thrust faults and related folds. Subsequent extension was accompanied by formation of normal faults, some with major displacement. The compressional deformation and at least some of the extensional movement predate deposition of the Eocene Challis Volcanic Group. This probable Cretaceous to Tertiary deformation is in addition to (1) Mesoproterozoic compressional deformation 
reported for local areas of the general region (for example, Evans, 1986; Evans and Zartman, 1990), and (2) Neoproterozoic to early Paleozoic extension, both of which may have affected rocks of the area. Normal displacement on several major faults in the Lemhi Range took place prior to uplift of the mountain range. The present topographic expression of the Lemhi Range and the adjacent mountain ranges is largely the effect of Cenozoic basin-and-range normal faulting (Ruppel, 1993).

Interpretations presented in this report differ significantly from those published previously. Rocks of the study area previously were interpreted as part of a single, regionally extensive thrust plate that crossed from central Idaho into southwestern Montana (Ruppel, 1978). Called the Medicine Lodge thrust system, it was perceived to include the thrust faults in the Beaverhead Mountains and adjacent areas of Montana, and the concept was later extended to include faults farther west in the Lemhi Range. Ruppel (1978) and Ruppel and Lopez (1984, 1988) envisioned the Medicine Lodge thrust as separating allochthonous rocks of the Mesoproterozoic Lemhi Group and overlying strata from subjacent, autochthonous, older Mesoproterozoic rocks of the Yellowjacket Formation. These workers considered the Yellowjacket to be autochthonous because they believed that, in most places, the rocks were only slightly deformed or exhibited a style of deformation different from that of strata of the Lemhi Group and younger rocks.

Within the Lemhi Range, Ruppel (1978, p. 8) stated that one of the best exposures of the Medicine Lodge fault system is in the vicinity of Mill Mountain, in the southeastern part of the present study area, where a window (the Hayden Creek window, fig. 4) resulted from erosion through the Medicine Lodge thrust plate. My mapping in this area and farther west in the northern part of the Lemhi Range (Tysdal, 1996a, 1996b, 1996c; Tysdal and Moye, 1996) leads me to conclude that the Medicine Lodge thrust plate does not exist in this part of the range, that no window was eroded through such a thrust plate, and that rocks assigned (by Ruppel and Lopez, 1988) to the Yellowjacket Formation in the northern part of the Lemhi Range are as intensely deformed as the rocks of other Mesoproterozoic formations.

\section{Stratigraphic Setting}

The stratigraphic succession, description, and thickness of rock units exposed in the study area are shown in table 1. Paleozoic strata crop out only locally, in the southern and northern parts of the study area. Volcanic rocks of the Eocene Challis Volcanic Group are extensively exposed on the flanks of the Lemhi Range, and locally atop the range. The sequence of Proterozoic formations shown in table 1 is in agreement with that determined by Ruppel (1968, 1975, 1980; Ruppel and Lopez, 1981), who set the stage for subsequent workers on Proterozoic stratigraphy in central Idaho during the course of their geologic mapping in the Lemhi Range. All Proterozoic rocks are metamorphosed to the lower greenschist facies, except for a local area of biotite-grade greenschist facies in the western part of the study area.

Discussion of the stratigraphy and interpretation of depositional environments represented in the Mesoproterozoic formations of the study area are presented in Tysdal (2000a). No strata of the Proterozoic Yellowjacket Formation (Ross, 1934) occur in the study area. The Yellowjacket was redefined by Tysdal (2000b) and restricted to strata like those originally assigned to the unit by Ross (1934). Rocks that Ruppel (1980), Lopez (1981), and Ruppel and Lopez (1988) designated as Yellowjacket within the Lemhi Range were reassigned to the Apple Creek Formation, and locally the Big Creek Formation, by Tysdal (1996a, 1996b, 1996c; Tysdal and Moye, 1996). Hence, in this report, strata that Ruppel $(1978,1980)$ and Ruppel and Lopez $(1984,1988)$ mapped or interpreted as Yellowjacket in the Lemhi Range here are designated "Yellowjacket" to distinguish the previous usage. This usage occurs mainly in the subsection on the Medicine Lodge thrust system.

\section{Compressional Deformation}

Structural terminology use in this report is summarized in the illustration of figure 3. The Poison Creek thrust fault, which trends northwest across the study area, is the major fault of the western part of the Lemhi Range. Hangingwall rocks of the Poison Creek thrust fault are named the Poison Creek thrust sheet, and those in the footwall are assigned to the McDevitt Creek thrust sheet. Subsidiary thrust and (or) normal faults of the Poison Creek sheet are the Hayden Creek and Bear Valley faults, which in their present configuration show normal displacement. The Hayden Creek fault, however, has a demonstrable thrust displacement prior to normal displacement. Both it and the Bear Valley fault may have formed originally as subsidiary thrusts of the Poison Creek thrust fault, generated during rupture of tight folds within the Poison Creek sheet, but attained only minor displacement. Rocks downdropped southwest of the Lem Peak normal fault are part of the Lem Peak block.

Major thrust faults are described first, followed by faults that have undergone multiple sense of movements. Then, the more recent movements are removed from these faults so as to look at early fault movements and to reconstruct the associated folds. A detailed evaluation of cleavage then is undertaken. Normal faults are described last.

\section{Poison Creek Thrust Fault}

The Poison Creek name was introduced by Soregaroli (1961) for a fault that trends northwest along Poison Creek in the northwestern part of the study area (fig. 4). An unnamed, concealed thrust fault was shown by Anderson (1961) in a structural section across the southwest $1 / 4$ of the Lemhi 15 -minute quadrangle (fig. 2). The name Poison Creek thrust fault is here applied to both previously recognized faults, interpreted as segments of one continuous feature. The name Hawley Creek thrust fault was applied to part of the Poison Creek thrust fault in the Lemhi Range by Skipp (1987) in a regional reconnaissance paper and by Skipp (1988). Janecke and others (2000) continued this usage in the Lemhi Range in a recent regional reconnaissance paper. The Hawley Creek name is not used for the fault because of reasons discussed in the last two paragraphs of this section of the present report. 
Table 1. Description and thickness of rock units within or directly adjacent to study area.

\begin{tabular}{|c|c|c|c|c|c|}
\hline AGE & \multicolumn{3}{|c|}{ STRATIGRAPHIC UNIT } & \begin{tabular}{|l|} 
THICK- \\
NESS (m)
\end{tabular} & DESCRIPTION \\
\hline 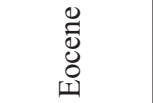 & \multicolumn{3}{|c|}{ Challis Volcanic Group } & $0-1,000$ & $\begin{array}{l}\text { Mainly flows of dacite, less abundant andesite, basalt, and rhyolitic ashflow tuff. Dacite and andesite locally form } \\
\text { autoclastic breccia, agglomerate. Local dikes, plugs, small intrusions of granodiorite in eastern part of study area. }\end{array}$ \\
\hline 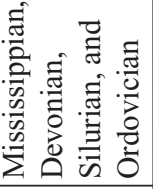 & \multicolumn{3}{|c|}{$\begin{array}{l}\text { Paleozoic carbonate rocks, } \\
\text { undivided }\end{array}$} & $350-400$ & $\begin{array}{l}\text { Mississippian Middle Canyon Formation-limestone, thin-bedded; locally silty. Devonian Jefferson Formation, } \\
\text { local small area near Hayden Creek-sucrosic dolomite. Ordovician and Silurian Saturday Mountain Formation- } \\
\text { dolomite, thin- to medium-bedded, locally massive, finely crystalline; minor limestone; vuggy in some places; } \\
\text { local chert nodules. All carbonate rocks form ledges and cliffs. }\end{array}$ \\
\hline ठ் & \multicolumn{3}{|c|}{ Kinnikinic Quartzite } & $300-400$ & Orthoquartzite, fine- to medium-grained. Tightly cemented, hard, resistant to erosion. Forms ridges and cliffs. \\
\hline 完: 离 & \multicolumn{3}{|c|}{ Altered intrusive rocks } & $0-100$ & $\begin{array}{l}\text { Sills, dikes, and one plug-shaped body. Some rocks are diabase, others gabbro, but most are so pervasively } \\
\text { cleaved and altered that classification is uncertain. Clots of calcite present within some rocks. }\end{array}$ \\
\hline \multirow{8}{*}{ 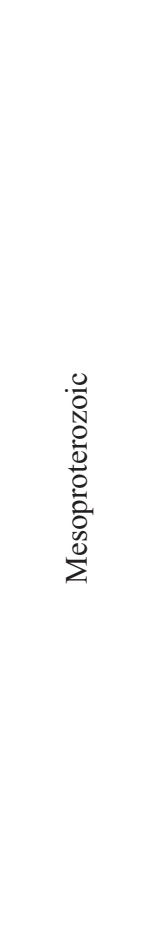 } & \multicolumn{3}{|c|}{ Lawson Creek Formation } & $300+$ & $\begin{array}{l}\text { Argillaceous siltite, siltite, and metasandstone. Metasandstone is generally quartz rich, locally a quartzite. Beds } \\
10-150 \mathrm{~cm} \text { thick. Only lower part of formation present in study area. }\end{array}$ \\
\hline & \multicolumn{3}{|c|}{ Swauger Formation } & 3,100 & Orthoquartzite and quartzite; minor siltite in upper part. Beds about $1 \mathrm{~m}$ thick. Resistant; forms ridges and cliffs. \\
\hline & \multirow{6}{*}{ 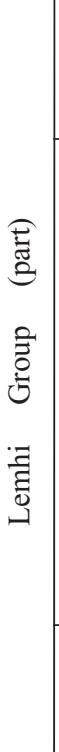 } & \multicolumn{2}{|c|}{ Gunsight Formation } & $100+$ & $\begin{array}{l}\text { Lenses of orthoquartzite in poorly exposed siltite. Lenses as thick as } 10 \mathrm{~m} \text {, extend laterally as much as } 100 \mathrm{~m} \text {. } \\
\text { Siltite is argillaceous, poorly exposed. Crops out only in northeastern part of Lem Peak quadrangle. Thickness } \\
\text { to north of quadrangle is } 1,500+\mathrm{m} \text {, where formation is mainly metasandstone and, in upper part, quartzite. }\end{array}$ \\
\hline & & \multirow{4}{*}{ 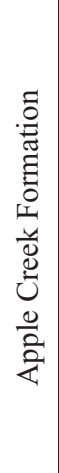 } & Banded siltite unit & $100+$ & $\begin{array}{l}\text { Alternating } 10-20-\mathrm{cm} \text { thick beds of siltite and fine-grained metasandstone. Exposed only in thrust slice along } \\
\text { Poison Creek fault, northwestern part of map area. }\end{array}$ \\
\hline & & & Coarse siltite unit & $2,500+$ & $\begin{array}{l}\text { Medium- to coarse-grained siltite and fine-grained metasandstone. Lower part contains beds as thick as } 50 \mathrm{~cm} \text { of } \\
\text { quartz-rich fine-grained metasandstone. Upper strata of unit generally are fine- to medium-grained siltite that } \\
\text { locally contains soft-sediment deformation structures. Upper part of unit is erosionally truncated. }\end{array}$ \\
\hline & & & Diamictite unit & $600-1,500$ & $\begin{array}{l}\text { Argillite, argillaceous siltite, and metasandstone. Contains pebbly strata in units a few meters thick that alternate } \\
\text { with non-pebbly argillite and siltite. Pebbles are dispersed, matrix-supported, and typically } 1-5 \mathrm{~cm} \text { in diameter. } \\
\text { Beds generally are only a few centimeters thick and are finely laminated. }\end{array}$ \\
\hline & & & Fine siltite unit & 1,000 & $\begin{array}{l}\text { Siltite and argillaceous siltite. Fine silt and clay content is most abundant in upper strata. Sparse matrix-supported } \\
\text { gravel-size argillite clasts form horizons one to two clast diameters thick locally in upper part of unit. }\end{array}$ \\
\hline & & \multicolumn{2}{|c|}{ Big Creek Formation } & 2,700 & $\begin{array}{l}\text { Coarse-grained siltite and fine- to medium-grained metasandstone, composed of quartz, feldspar, minor matrix. } \\
\text { Heavy-mineral laminae widespread. Carbonate laminae common. Dunes common. Upper part of unit contains } \\
\text { sparse zones, as thick as } 10 \mathrm{~m} \text {, of dark-gray argillaceous siltite. Beds commonly about } 1 \mathrm{~m} \text { thick. }\end{array}$ \\
\hline
\end{tabular}



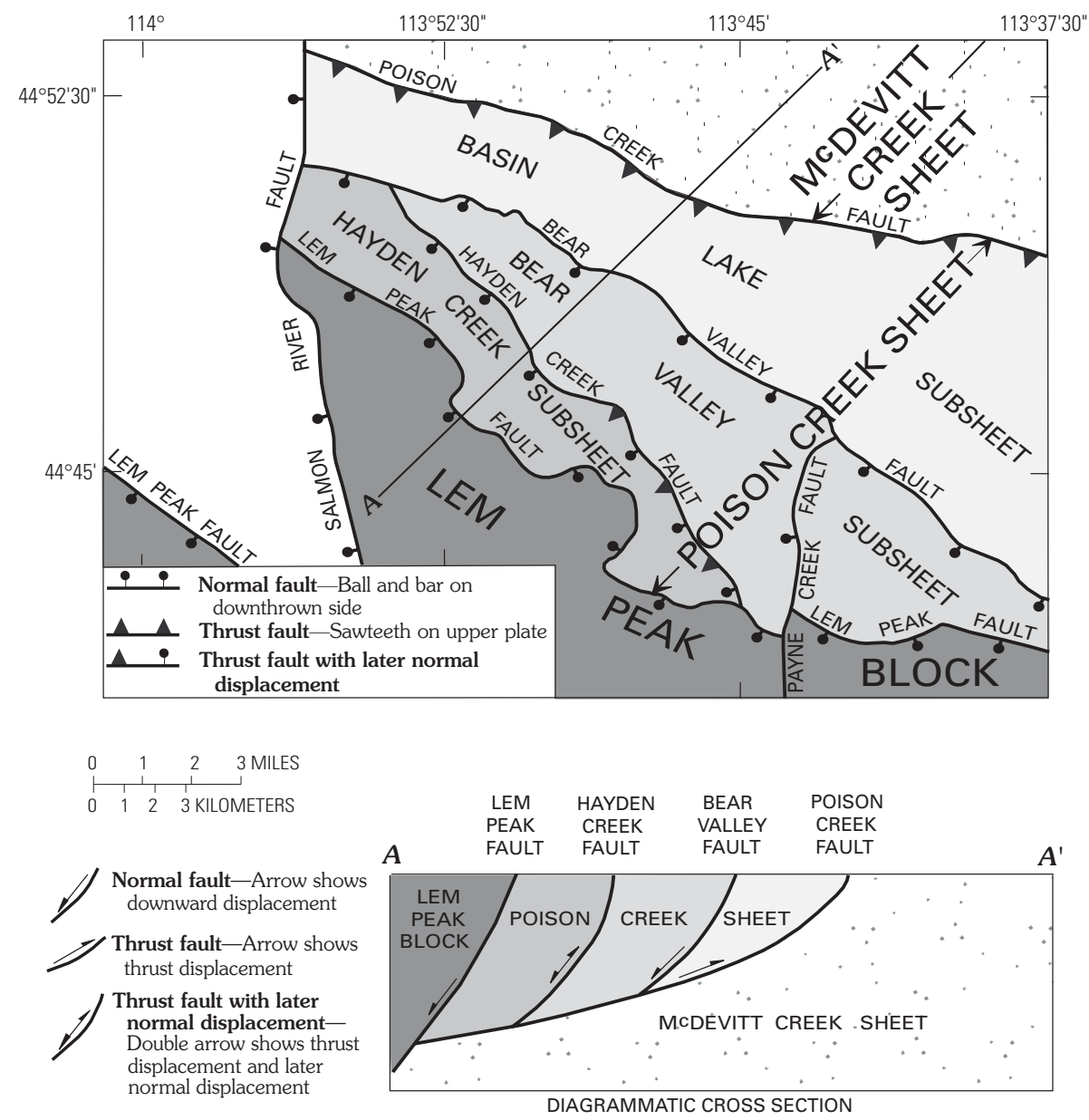

Figure 3. Tectonic map showing major faults, thrust sheets and subsheets, and diagrammatic section across these structures of study area.

Soregaroli (1961) interpreted the Poison Creek fault as a high-angle reverse fault, which he described as dipping $68^{\circ} \mathrm{SW}$. For an area directly south of Poison Peak, I used a three point construction to determine a dip of $30^{\circ}-35^{\circ} \mathrm{SW}$. (The profile of the present erosion surface from Poison Peak to Poison Creek is $30^{\circ}$, indicating a minimum dip necessary for the fault.) Measurement on a $25 \mathrm{~m}$ long exposure of the fault surface, parallel to the dip of the fault, yielded an inclination of $40^{\circ} \mathrm{SW}$. The concealed segment of the fault mapped by Anderson (1961) in the Lemhi 15-minute quadrangle (fig. 2) displays the same structural relationships as in the northwestern part of the map area of figure 4.

The exposed part of the Poison Creek thrust fault, and the directly down-dip part of the fault illustrated in the cross sections (figs. 5, 6, and 7), shows the $30^{\circ}-35^{\circ} \mathrm{SW}$. dip of the fault. This inclined fault surface is interpreted to be only the ramp of a major thrust fault that transported hangingwall strata to the northeast. Beneath the depth of the cross sections, the fault surface likely becomes nearly horizontal, as shown diagrammatically in cross section $A-A^{\prime}$ of figure 3 . Similarly, the fault surface is interpreted to have been nearly horizontal in nearly flat lying rock that has been eroded from above the nearly horizontal strata that underlie the present land surface of the exposed part of the McDevitt Creek sheet footwall. The rocks of the footwall McDevitt Creek sheet directly beneath the inclined part of the Poison Creek thrust fault thus constitute a footwall ramp; those beneath the (interpreted) nearly horizontal part of the fault constitute a footwall flat. The amount of horizontal transport on the fault is unknown, although it could be several tens of kilometers.

The Poison Creek fault displaced Mesoproterozoic strata against lower Paleozoic formations composed of carbonate and quartzite (fig. 4) in the western part of the Lemhi Range. Areas of lower Paleozoic units occur discontinuously in the footwall from the Poison Peak area on the northwest to east of Hayden Creek on the east. Anderson (1961, pl. 1) showed the fault only in his cross section $C-C^{\prime}$, not on his geologic map of the Lemhi quadrangle (fig. 2) where the fault trace lies beneath Quaternary sediments, but he showed the same relationship of Mesoproterozoic rocks displaced over lower Paleozoic strata as exists along the Poison Creek fault west of the Lemhi quadrangle. Stratigraphic displacement across the Poison Creek thrust fault is $10,000-12,000 \mathrm{~m}$.

The Hawley Creek thrust fault was originally mapped by Lucchitta (1966) along the southwest flank of the Beaverhead Mountains east of Leadore (fig. 1). Skipp (1987) recognized that the Hawley Creek fault is a zone of thrust faulting that extends into the Lemhi Range. She applied the Hawley Creek 


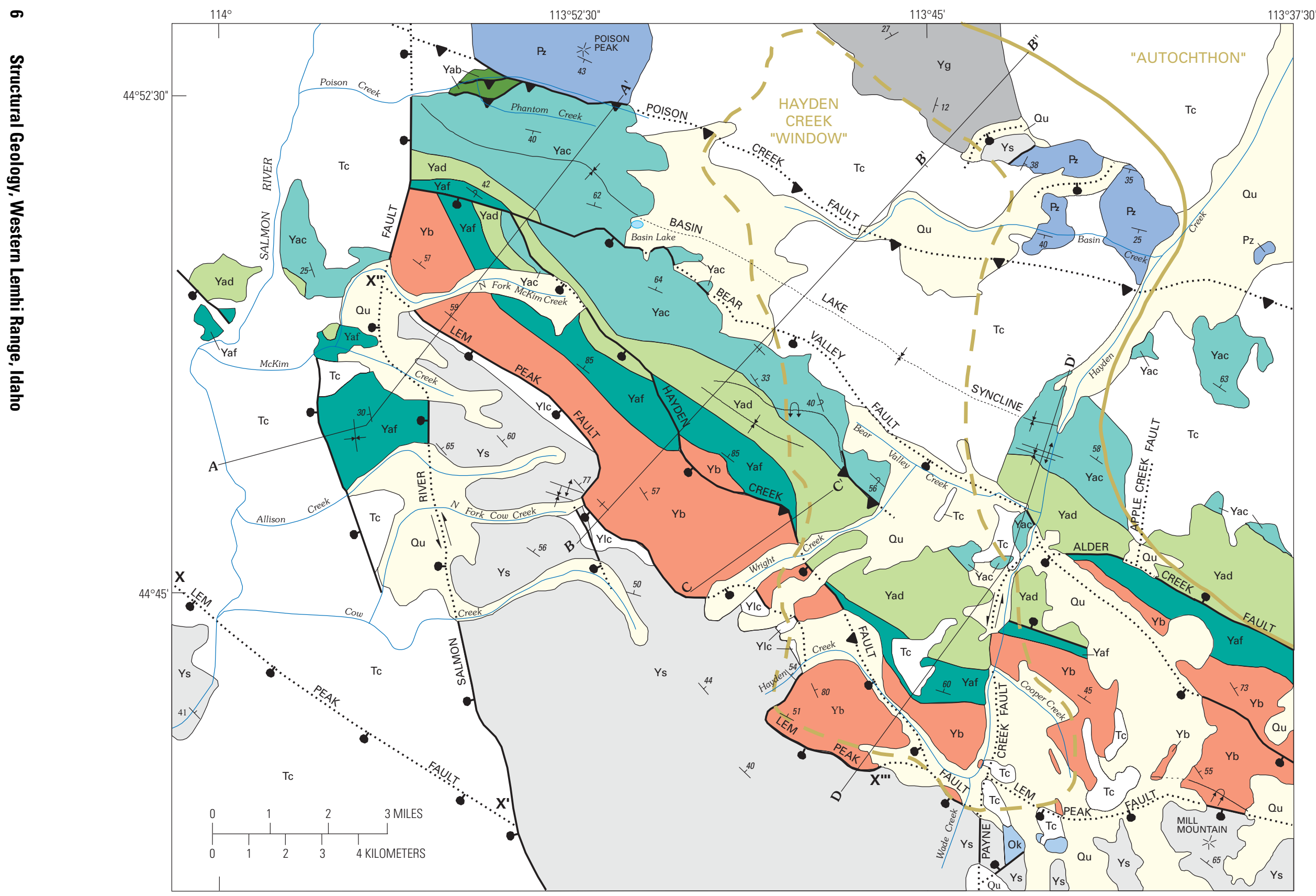

Figure 4 (above and facing page). Geologic map of study area in western part of Lemhi Range, compiled from maps of Tysdal (1996a; 1996b), Tysdal and Moye (1996), and Tysdal (unpub. mapping, 1996-2000). Bold gold line shows outline of Hayden Creek "window" (dashed) and edge of "autochthon" (solid) of Ruppel and Lopez (1984). Cross sections are shown in figures $5-8$. 


\section{EXPLANATION}

$\begin{array}{ll}\text { Qu } & \text { Quaternary sediments, undivided } \\ \text { Tc } & \text { Eocene Challis Volcanic Group } \\ \mathrm{Pz} & \text { Paleozoic carbonate rocks, undivided } \\ \mathrm{Ok} & \begin{array}{l}\text { Ordovician Kinnikinic Quartzite } \\ \text { Mesoproterozoic units }\end{array} \\ \text { Ylc } & \text { Lawson Creek Formation } \\ \text { Ys } & \text { Swauger Formation } \\ \text { Yg } & \text { Gunsight Formation } \\ & \text { Apple Creek Formation } \\ \text { Yab } & \text { Banded siltite unit } \\ \text { Yac } & \text { Coarse siltite unit } \\ \text { Yad } & \text { Diamictite unit } \\ \text { Yaf } & \text { Fine siltite unit } \\ \text { Yb } & \text { Big Creek Formation }\end{array}$

\begin{tabular}{|c|c|}
\hline & Contact \\
\hline$\stackrel{x \ldots}{=}$ & $\begin{array}{l}\text { Normal fault-Dotted where concealed } \\
\text { ball and bar on downthrown side; } \\
\text { arrows show relative lateral movement } \\
\text { directions; } \mathbf{X}, \mathbf{X}, \mathbf{X} \text { ", } \mathbf{X} \text { '" denote fault } \\
\text { segments discussed in text }\end{array}$ \\
\hline & $\begin{array}{l}\text { Tear fault-Dotted where concealed; } \\
\text { arrows show relative lateral movement } \\
\text { directions }\end{array}$ \\
\hline ــــ & $\begin{array}{l}\text { Thrust fault-Dotted where concealed; } \\
\text { sawteeth on upper plate }\end{array}$ \\
\hline - & $\begin{array}{l}\text { Thrust fault with later normal } \\
\text { displacement-Dotted where } \\
\text { concealed; sawteeth on upper plate; } \\
\text { ball and bar on downthrown side }\end{array}$ \\
\hline$t$ & $\begin{array}{l}\text { Syncline-Showing trace of axial plane; } \\
\text { dotted where concealed }\end{array}$ \\
\hline$\widehat{\uparrow}$ & $\begin{array}{l}\text { Overturned syncline-Showing trace } \\
\text { of axial plane }\end{array}$ \\
\hline$\uparrow$ & Anticline-Showing trace of axial plane \\
\hline 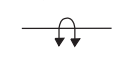 & $\begin{array}{l}\text { Overturned anticline-Showing trace } \\
\text { of axial plane }\end{array}$ \\
\hline$B-B^{\prime}$ & Cross section line \\
\hline & Strike and dip of beds \\
\hline$x^{64}$ & Inclined \\
\hline+ & Vertical \\
\hline $40 \nmid$ & Overturned \\
\hline
\end{tabular}

name to the zone in the Lemhi Range. I do not follow this usage in the Lemhi Range for the following two reasons:

1. The Poison Creek thrust fault displaced Mesoproterozoic rocks over Paleozoic strata; Paleozoic strata are not part of the hangingwall sheet of the Poison Creek thrust fault. The geologic map of Lucchitta (1966, pls. 1, 2) shows that the Hawley Creek fault has placed uppermost Mesoproterozoic rocks and depositionally overlying lower Paleozoic strata (and crosscutting Ordovician-Silurian granite) over younger Paleozoic rocks. In the Lemhi Range, this structural relationship is akin to one of the subsidiary imbricate thrust faults mapped by K.V. Evans, Falma Moye, and R.F. Hardyman (unpub. mapping, 1996) and Evans, K.I. Lund, and Tysdal (work in progress) in the McDevitt Creek sheet that is footwall to the Poison Creek thrust fault: latest Mesoproterozoic and depositionally overlying lower Paleozoic strata are thrust northeastward over lower Paleozoic and depositionally underlying Mesoproterozoic strata.
2. Stratigraphic separation on the Hawley Creek thrust fault of the Beaverhead Mountains, and that on the imbricate thrust faults in the McDevitt Creek sheet (footwall) mapped by K.V. Evans, Falma Moye, and R.F. Hardyman (unpub. mapping, 1996) and Evans, K.I. Lund, and Tysdal (work in progress) in the Lemhi Range, are minor relative to that of the Poison Creek thrust fault. Therefore, the Hawley Creek sheet might be the appropriate name for the footwall sheet in the Lemhi Range. However, because the Hawley Creek thrust sheet probably contains several footwall imbricate thrusts of a more major thrust fault that is equivalent to the Poison Creek thrust fault and that is concealed beneath the Leadore Valley, the Hawley Creek name is not used in the Lemhi Range. The position of the Poison Creek thrust fault concealed beneath the Leadore Valley is shown by Evans, K.I. Lund, and Tysdal (work in progress).

\section{Hayden Creek and Bear Valley Faults}

The Hayden Creek and Bear Valley faults in their present structural relationships are normal faults. The present offset is normal. However, I interpret the Hayden Creek fault to have formed initially as a splay from the Poison Creek thrust fault (fig. 3). The thrust displacement formed to relieve stress in tightly folded strata. The splay may have acted to dissipate slip on the Poison Creek thrust fault, a role for secondary thrusts suggested by Mitra (1990, p. 934). The Bear Valley fault also may have formed this way, but the present relationship is entirely normal displacement. The two faults merge in the northwestern part of the study area. Interpretation of the complex pattern in the area of intersection, shown in cross section $A-A^{\prime}$ (fig. 5), requires that description and interpretation of the individual faults be presented first.

\section{Hayden Creek Fault}

The Hayden Creek fault trends northwest across the study area (figs. 3,4). It is truncated by the Lem Peak normal fault on the southeast and merges with the Bear Valley fault on the northwest. The fault dips moderately to the southwest in its south half, but in the northwest, the fault steepens to vertical, indicated by a fairly straight trend across terrain of considerable differential relief. Farther northwest, in the vicinity of the intersection with the Bear Valley fault, the dip of the Hayden Creek fault changes to steep northeast. The northeast dip is related to normal faulting of folded strata, as explained later. The Hayden Creek fault zone locally is marked by a several-meter-thick white fault gouge; in other places it contains veins, pods, and stringers of white vein quartz. These characteristics are indicative of extension. In contrast, rocks on the northeast side of the fault indicate compressional deformation because of tight folding and intensely developed cleavage and shearing.

In the vicinity of Wright Creek (fig. 4), rocks on the southwest side of the Hayden Creek fault form a northeast-facing salient, or "flap," over rocks east of the fault. The "flap" forms a hangingwall composed of the Mesoproterozoic Big Creek Formation and overlying lower strata of the fine siltite unit of the 

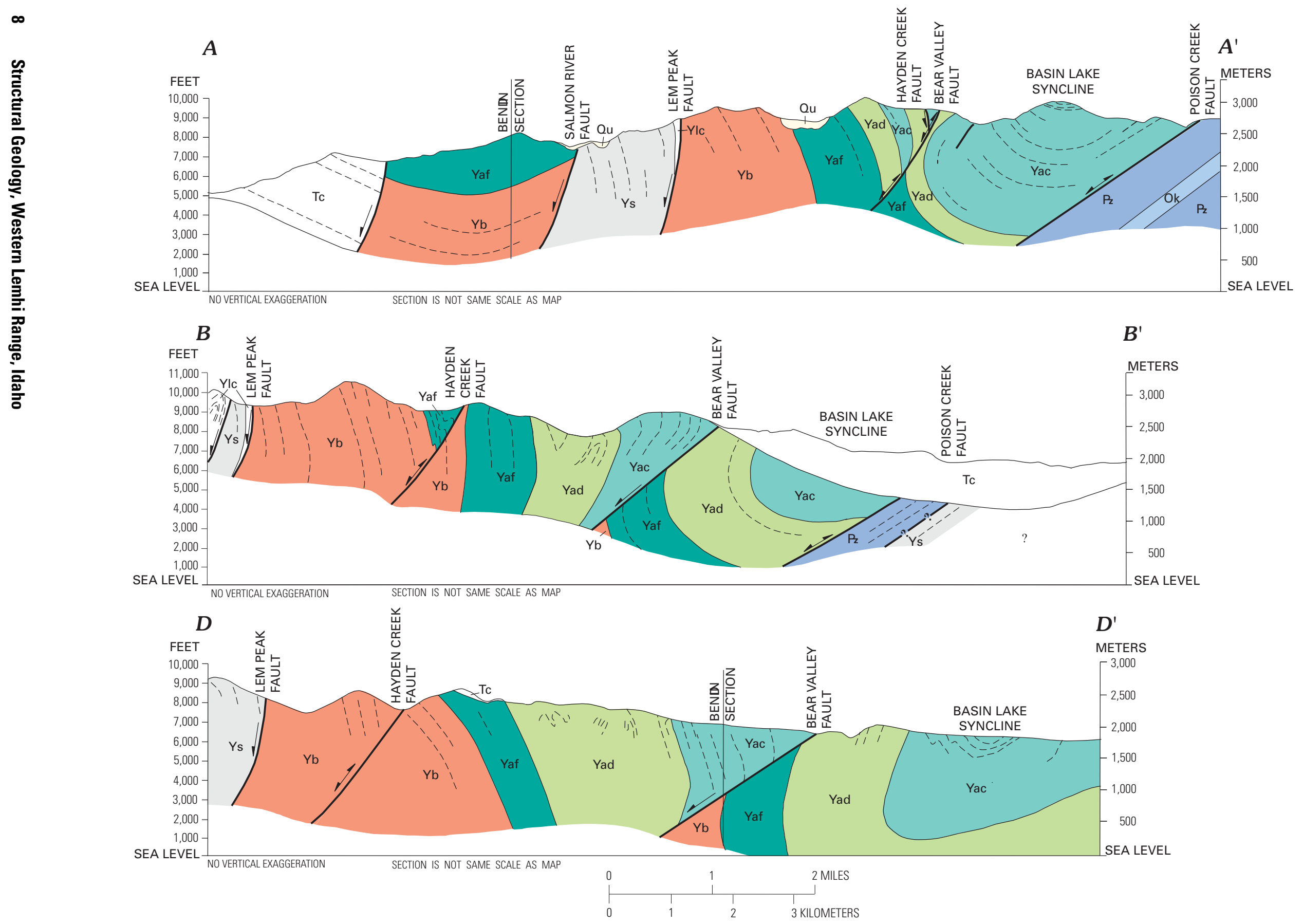

Figure 5 (above and facing page). Cross sections $A-A^{\prime}, B-B^{\prime}$, and $D-D^{\prime}$. Cross section $C-C$ is shown in figure 8. Lines of cross sections are shown in figure 4. 


\section{EXPLANATION}

$\begin{array}{ll}\text { Qu } & \text { Quaternary sediments, undivided } \\ \text { Tc } & \text { Eocene Challis Volcanic Group } \\ \text { Pz } & \text { Paleozoic carbonate rocks, undivided } \\ \text { Ok } & \text { Ordovician Kinnikinic Quartzite } \\ & \text { Mesoproterozoic units } \\ \text { Ylc } & \text { Lawson Creek Formation } \\ \text { Ys } & \text { Swauger Formation } \\ \text { Yg } & \text { Gunsight Formation } \\ & \text { Apple Creek Formation } \\ \text { Yac } & \text { Coarse siltite unit } \\ \text { Yad } & \text { Diamictite unit } \\ \text { Yaf } & \text { Fine siltite unit } \\ \text { Yb } & \text { Big Creek Formation }\end{array}$

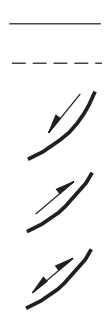

\section{Contact}

Bedding

Normal fault-Arrow shows downward movement

Thrust fault-Arrow shows thrust movement

Thrust fault with later normal displacementDouble-barbed arrow shows both directions of movement

Apple Creek Formation (fig. 8). There, footwall strata are composed of the fine siltite unit and the diamictite unit of the Apple Creek Formation. Directly beneath the flap and to the northeast, footwall strata contain tight folds that display steep southwestdipping axial planes. Northwest of the flap, this pattern of tight folds, some with overturned limbs, continues along strike for several kilometers. The folds are compressional structures, but the map pattern shows Apple Creek strata displaced over Gunsight Formation, reflecting normal displacement on the Hayden Creek fault. Removal of the normal displacement, and calculations of thickness and structural orientation of strata of the flap relative to concealed strata of the fine siltite unit, indicate that a thrust relationship exists in the vicinity of the flap, as shown in cross section $C-C^{\prime}$ (fig. 8). Normal displacement was not sufficient to reverse the thrust relationship. The following paragraphs explain the analysis ${ }^{2}$.

On the map of Tysdal (1996b), the Yb/Yaf contact at the western margin of the flap (vicinity of $Y-Y^{\prime}$ ) was shown northeast of where it is shown in figure 8, due to an error made in the original mapping. The $\mathrm{Yb} / \mathrm{Yaf}$ contact near point $\mathrm{Y}$ is the correct location. The nearly vertical fault about $0.25 \mathrm{~km}$ northeast of the newly placed contact is of unknown magnitude. The following calculations make use of the newly placed contact. Using the contact as previously placed would only reinforce the conclusion concerning early thrust fault displacement.

1. Removal of the offset that now exists between the $\mathrm{Yb} /$ Yaf contact of the flap and the $\mathrm{Yb} / \mathrm{Yaf}$ contact directly north of the flap (fig. 8, points $Y$ and $Y^{\prime}$ ) is accomplished by moving the hangingwall northeastward up the plane of the fault, which dips

\footnotetext{
${ }^{2}$ The rock symbols of the map in figure 8 are used in the following explanation; otherwise, the unit terminology becomes too cumbersome: $\mathrm{Yb}$, Big Creek Formation; Yaf, Apple Creek Formation, fine siltite unit.
}

about $45^{\circ} \mathrm{SW}$. in the area of the flap, and for about $4 \mathrm{~km}$ to the northwest (fig. 8, section $C-C^{\prime}$ ). This reconstruction results in the $\mathrm{Yb} / \mathrm{Yaf}$ contact of the two subsheets becoming one contiguous contact. The vertical distance from the $\mathrm{Yb} / \mathrm{Yaf}$ contact of the footwall to the $\mathrm{Yb} / \mathrm{Yaf}$ contact of the hangingwall is about $700 \mathrm{~m}$. Because the two legs of a $45^{\circ}$ right-angle triangle are equal, the existing horizontal distance between the $\mathrm{Yb} / \mathrm{Yaf}$ contact of the hangingwall and the footwall also is about $700 \mathrm{~m}$.

2. At the north edge of the flap (that is, north of the eastwest part of the Hayden Creek fault), the northwest-striking Yaf unit disappears southward beneath ("dives under") the flap. Its upper strata and upper contact emerge about $2.5 \mathrm{~km}$ to the southeast (fig. 8). The approximate location of the concealed Yab/ Yaf contact, traced on the map, must change trend from a northwest strike north of the flap to an almost south strike beneath the flap to permit Yaf strata north of the flap to connect with Yaf strata southeast of the flap. (This change of direction cannot be due to topography because the steep to moderate northeast dips of unit Yaf beds would require that the concealed Yaf unit change direction to an east trend, and thus would have to crop out northeast of the flap.) The thickness of unit Yaf is about 900 $\mathrm{m}$, but because of internal folding and moderate dips, the unit appears somewhat thicker.

3. Considering the $45^{\circ} \mathrm{SW}$.-dipping section of the Hayden Creek fault, removal of the offset that now exists between the $\mathrm{Yb} /$ Yaf contact at the south edge of the flap (fig. 8, point $Z^{\prime}$ ) and the concealed contact directly to the southwest (fig. 8, point $Z$ ) requires a horizontal component of movement of 1,050-1,200 $\mathrm{m}$. (And, because the two legs of a $45^{\circ}$ right-angle triangle are equal, the vertical component of offset of the $\mathrm{Yb} / \mathrm{Yaf}$ contact also is $1,050-1,200 \mathrm{~m}$.) This measurement is considerably greater than the $700 \mathrm{~m}$ determined for the northern part of the flap.

4. The trace of the $\mathrm{Yb} / \mathrm{Yaf}$ contact of the hangingwall flap does not trend south in concert with the $\mathrm{Yb} / \mathrm{Yaf}$ contact in the concealed footwall, but continues its southeast orientation in agreement with the recorded strikes of the flap. No strikes observed anywhere within the hangingwall display the southerly trends required for agreement with the strikes required in the concealed Yaf unit of the footwall. No tight folding in the rocks of the flap is recorded that would permit the contact in the hangingwall and footwall to accommodate the $45^{\circ}$ difference in trend indicated in figure 8. But the two trends could be accommodated if a fold, now cut out by the normal fault movement, had existed previously between the hangingwall flap and the footwall rocks. Overturned Yaf and $\mathrm{Yb}$ beds in the northwestern part of the footwall suggest that this possibility is real. The difference in strike orientation of beds in the hangingwall flap and the concealed footwall strata then could be accommodated by kinking of the fold. Such a structure would be compressional, in concert with observed minor structures of the footwall.

In any case, removal of $700 \mathrm{~m}$ of normal-slip displacement on $Y-Y^{\prime}$ is insufficient to account for all of the 1,050-1,200 $\mathrm{m}$ of reverse-slip offset along $Z-Z^{\prime}$. Restoration of $Y-Y^{\prime}$ to a pre-normal-slip position yields a larger thrust fault relationship in the area of $\mathbf{Z}-\mathbf{Z}^{\prime}$. This indicates that early thrust faulting took place and that later normal displacement was not sufficient to entirely reverse the thrust displacement. 


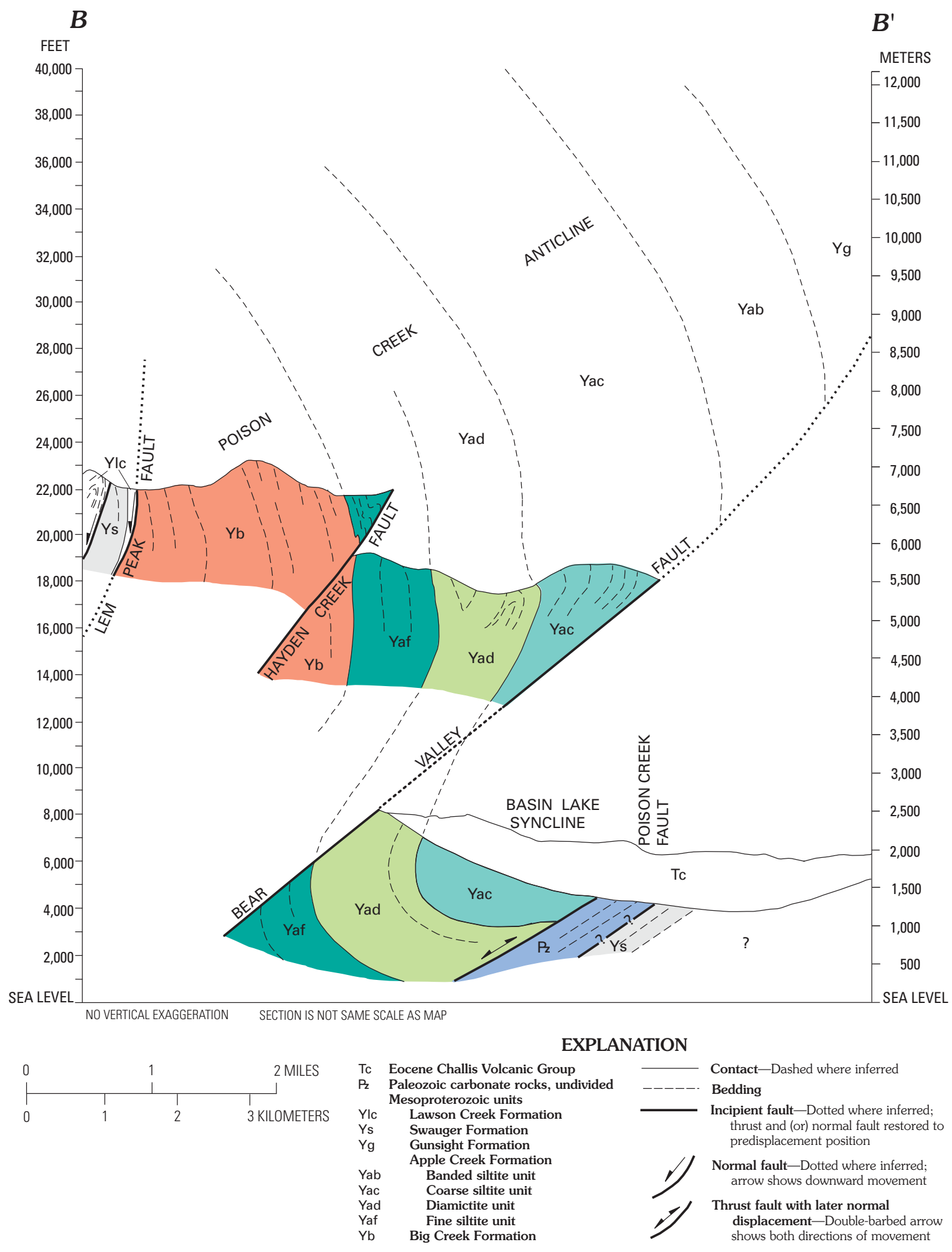

Figure 6 (above and facing page). Cross sections $B-B^{\prime}$ and $D-D^{\prime}$ as reconstructed after normal-slip displacement removed from faults. Figure 9 shows the reconstructed segment of cross section $A-A^{\prime}$ for which normal-slip has been removed. No reconstruction is shown for cross section $C-C^{\prime}$.

\section{Bear Valley Fault}

The Bear Valley fault trends northwest, dips to the southwest, and is flanked on the northeast by the Basin Lake syncline (fig. 4). Features suggestive of extension are common along the fault. Intensely developed southwest-dipping cleavage is cut by fractures that are filled with quartz veins as thick as $10 \mathrm{~cm}$; quartz masses as much as $0.5 \mathrm{~m}$ across were observed in some areas. Chloritic alteration occurs in some areas and silicification was observed locally in the northern extent of the fault. Cobblesize pieces of undeformed specular hematite characterize float in both the northern and the southern extent of the fault. 


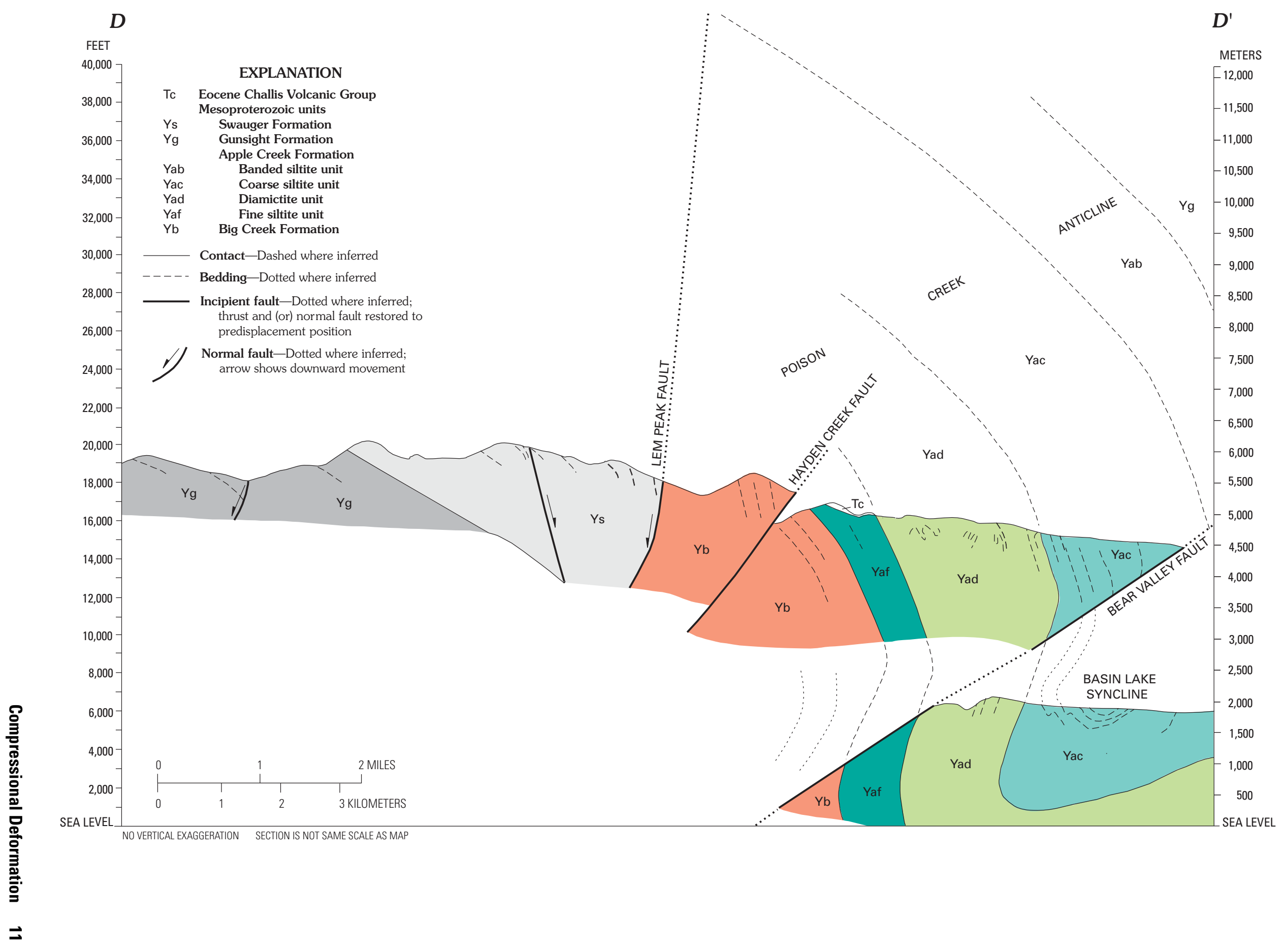


FEET

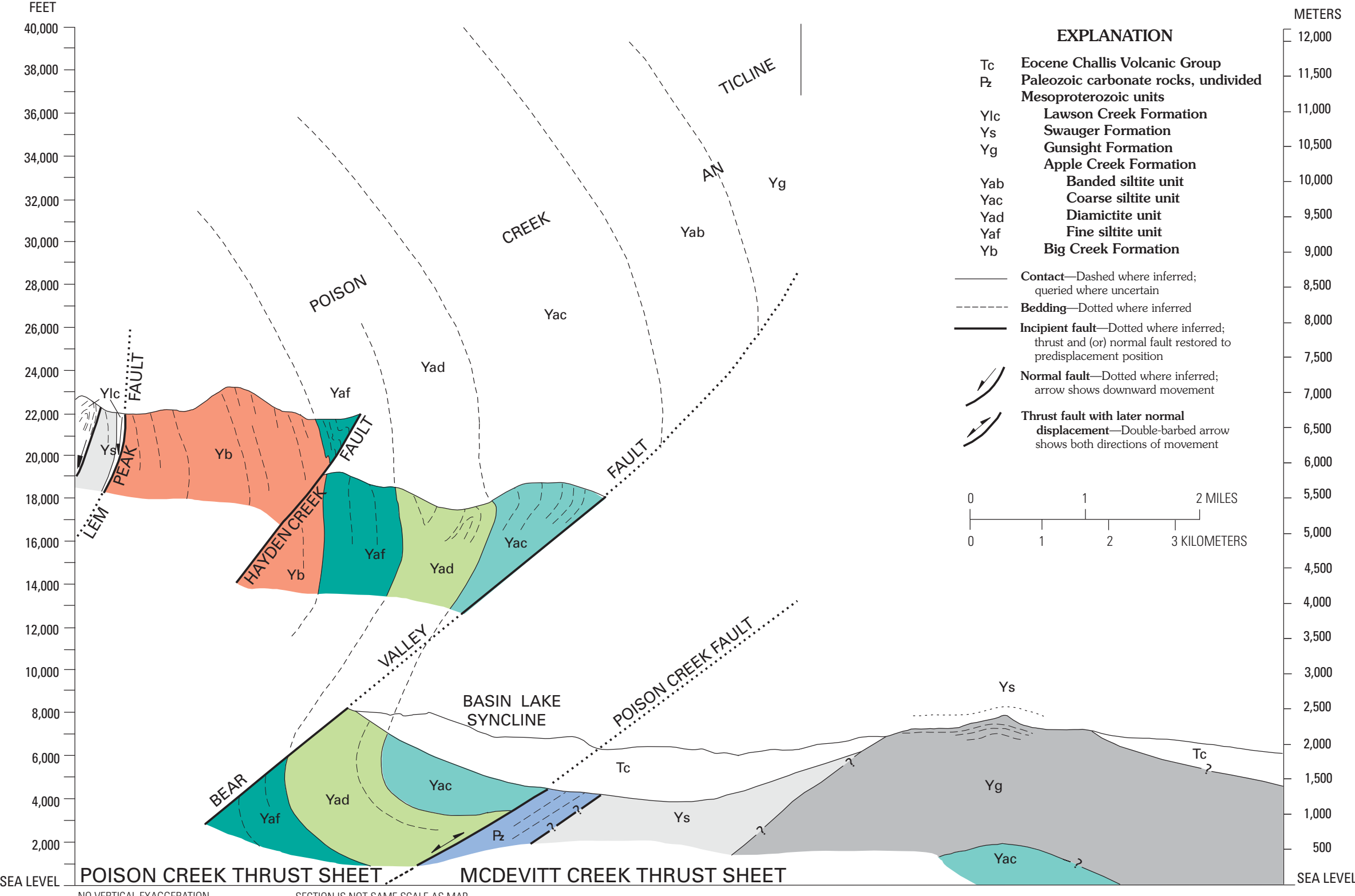

SEA LEVEL $\frac{\text { POISON CREEK }}{\text { NO VERTICAL EXAGGRATION }}$

SECTION IS NOT SAME SCALE AS MAP

Figure 7. Cross section showing relationship of Poison Creek anticline of Poison Creek sheet and the McDevitt Creek footwall sheet. The anticline is from reconstructed cross section $B-B^{\prime}$ shown in figure 6. See text for explanation and interpretations. 


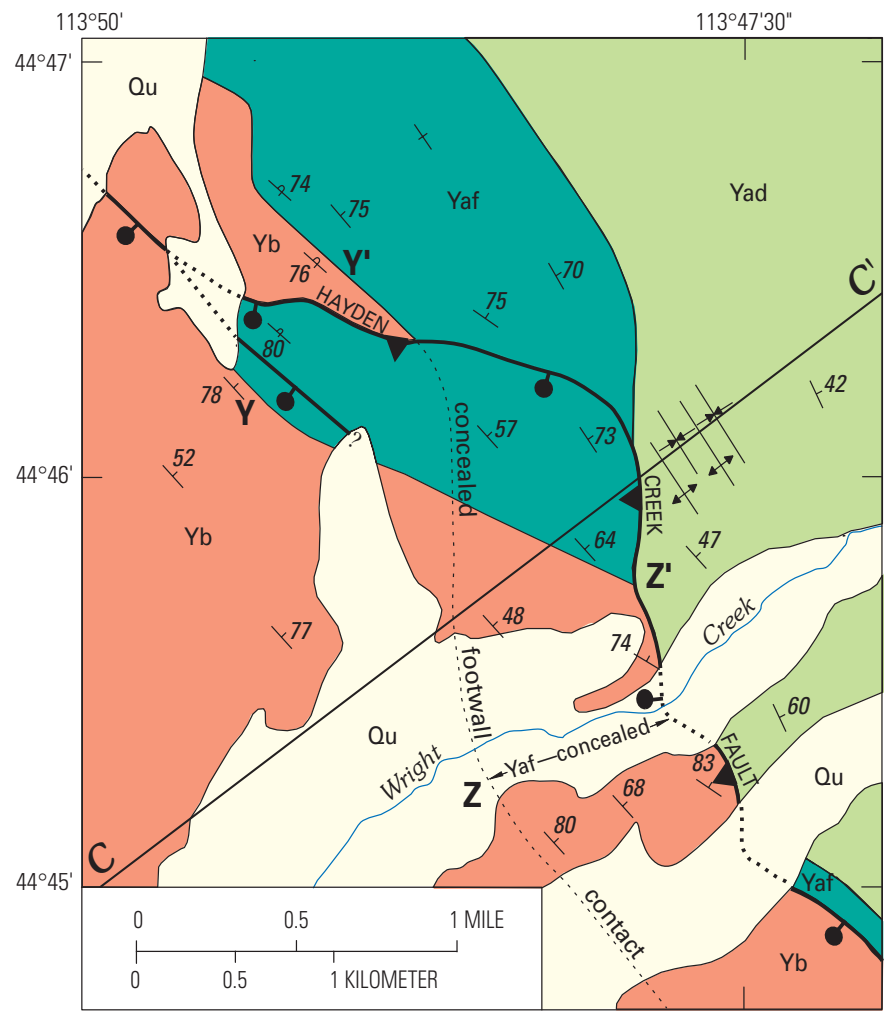

\section{EXPLANATION}

Qu

Yaf

$\mathrm{Yb}$
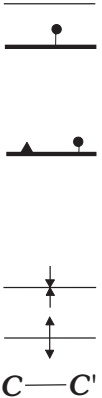

$C-C$

$x^{48}$

$+$

801

Quaternary sediments, undivided

Mesoproterozoic units

Apple Creek Formation

Diamictite unit

Fine siltite unit

Big Creek Formation

Contact-Dotted where concealed

Normal fault-Dotted where concealed; ball and bar on downthrown side; queried where uncertain

Thrust fault with later normal displacement-Dotted where concealed; sawteeth on upper plate; ball and bar on downthrown side

Syncline - Showing trace of axial plane

Anticline-Showing trace of axial plane

Cross section line

Strike and dip of beds

Inclined

Vertical

Overturned

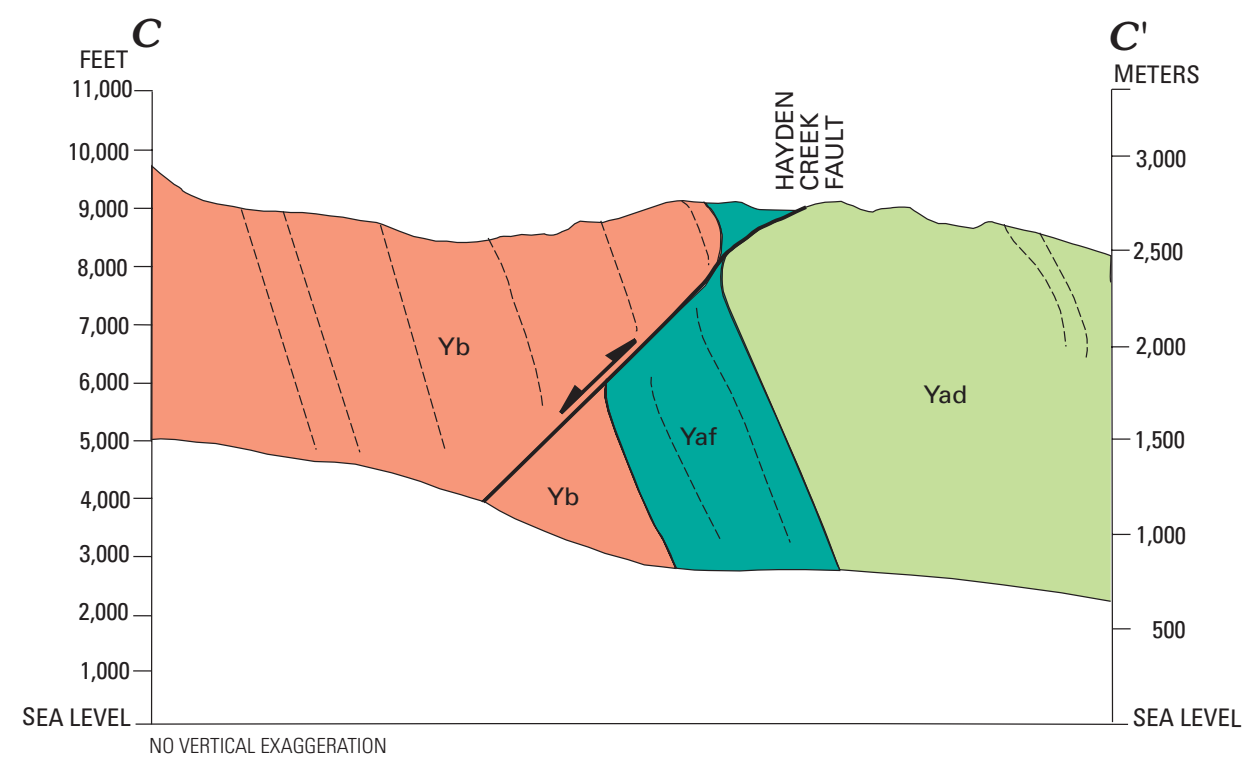

Figure 8. Geologic map and cross section of area where Hayden Creek fault shows both thrust and normal displacement. Vicinity of Wright Creek, south-central part of study area (fig. 4). See text for interpretation. Cross section $C-C^{\prime}$ is the same as that shown by Tysdal (1996a), except that here the northeast end is truncated at the limit of the area shown in the map view. Y, $Y^{\prime}, Z$, and $Z^{\prime}$ are points of reference used in the interpretation of fault movements as discussed in the text. Quaternary unconsolidated sediments are not shown on cross section. Concealed rocks of lower sheet shown. In cross section, double-barbed arrow along fault indicates thrust movement followed by later normal-slip displacement; light dashed lines, bedding.

The Bear Valley fault shows normal displacement in its present structural relationship (Tysdal, 1996a, 1996b). However, the fault may have formed originally as a minor thrust and later underwent normal-slip. Metasandstone within 100-300 m of the fault is intensely cleaved locally, whereas farther away the cleavage is less intense. The intensely developed cleavage dips $30^{\circ}-40^{\circ} \mathrm{SW}$., similar to the regional cleavage. In its southeastern part, the fault is a zone that is entirely within the Big Creek Formation; footwall strata are not overturned, and I cannot determine the existence of compressional features. In the 
northwest part of the study area, overturned footwall strata of the Bear Valley fault host intensely developed cleavage that dips southward at moderate angles.

Abundant closely spaced folds (wavelengths 100-300 m) characterize deformation in the Basin Lake syncline along Hayden Creek (fig. 4; fig. 5, cross section $D-D^{\prime}$ ). The folds form pairs in the diamicite and coarse siltite units of the Apple Creek Formation in the lower part of the Bear Valley subsheet along Hayden Creek: the repeated pattern is of a closely spaced anticline-syncline pair separated by several hundred meters from another closely spaced fold pair. Folds in the coarse siltite unit of the hangingwall in the area directly east of Wright Creek are more open than those in the coarse siltite unit of the Apple Creek Formation in the footwall of the Bear Valley fault (Basin Lake subsheet) in the Hayden Creek area and southeastward. This contrast likely reflects the higher percentage of coarse siltite to fine-grained metasandstone beds in the Wright Creek area. Flowage is characteristic of the clay-rich fine-grained siltite between the coarser interbeds of the Wright Creek area and is characteristic of the diamictite of the Hayden-Alder Creek area.

Along the central extent of the Bear Valley fault, beds at the leading edge of the hangingwall steepen progressively (from southwest to northeast) toward the fault, in the process of rolling over to form the steep limb of an anticline that is the counterpart of the Basin Lake syncline (fig. 5, cross section $B-B^{\prime}$ ). Only part of the anticlinal limb is now preserved, and it is displaced to the southwest due to normal movement on the Bear Valley fault. The two folds form an anticline/syncline couple, sharing one fold limb that is referred to as the common limb.

Overturning of beds in the anticlinal limb of the fold-couple became so great locally that a minor thrust fault developed within the Bear Valley subsheet directly west of Wright Creek (fig. 4). This minor thrust fault, directly northeast of the northeast end of section $C-C^{\prime}$ (fig. 4), developed at the upper contact of the diamictite unit and displaced the diamictite unit onto overturned strata of the coarse siltite unit, both of the Apple Creek Formation. The minor thrust fault gives way northwestward to an overturned anticline, then an upright anticline. The actual connection of the thrust segment with the anticline is an interpretation in an area of poor exposures, but the strata are consistently overturned for the full $3 \mathrm{~km}$ of the trend. Southeast from Wright Creek, the minor thrust fault is covered; directly west of Hayden Creek, the contact is depositional.

The Bear Valley fault formed along the axial area of the anticline/syncline fold-couple that is seen along the central area of the Bear Valley fault. The cross sections of figure 6 are reconstructions across this central area after removal of the normalslip shown in the faults of figure 5, and with the anticline of the fold-couple placed above the syncline. This depicts the fold at an initiation point of thrusting to the northeast or normal-slip displacement to the southwest. The Bear Valley fault, northeast of cross section $C-C^{\prime}$, is covered by volcanic rocks and the dip there is uncertain, but it probably is similar to sections $B-B^{\prime}$ and $D-D^{\prime}$. These sections show that the fault developed along the common, stretched limb of the fold-couple. (Its dip has been reinterpreted-decreased-from that shown on the map of Tysdal (1996b) to be similar to that in cross sections $B-B^{\prime}$ and $D-D^{\prime}$ of fig. 6.)
Normal-fault movement of the hangingwall placed strata from a higher structural level of the fold-couple (southwest of the fault) adjacent to rocks of the lower structural level on the footwall Basin Lake subsheet (northeast of the fault) (fig. 5, cross section $B-B^{\prime}$ ). The lowest structural level exposed along the Bear Valley fault is in the southeast, the highest level in the northwest. Similarly, older strata are most extensively exposed in the southeast and younger strata in the northwest. From southeast to northwest, the reconstructed cross sections of figure 6 permit an along-structure (as opposed to down-structure) view of the Bear Valley fault and the now-separated limbs of the foldcouple from deeper to shallower structural levels. The fault cuts upward from the Big Creek Formation, along the extended common limb of the anticline/syncline fold-couple (fig. 6, cross section $D-D^{\prime}$ ), and farther upward through the diamictite unit of the Apple Creek Formation and into younger strata of the coarse siltite unit of the formation (fig. 6 , cross section $B-B^{\prime}$ ).

\section{Restoration to Pre-Normal Fault Displacement}

The Bear Valley and Hayden Creek faults have been restored to pre-normal-slip geometries (1) to give an indication of the scale of structures in the area and in the larger region (fig. $6)$; (2) to give an indication of the type and scale of folding present; (3) to show the relationships of faults to the major fold of the study area, placing them in a perspective that permits an interpretation of their origin; and (4) to provide a way to interpret stereonet data-which reflect compressional deformationfrom fold components that are in their approximate relative positions at the end of compression and just prior to extensional deformation. The pre-restored cross sections (fig. 5) were constructed at a scale of 1:24,000 and accompanied the published geologic maps (Tysdal, 1996a, 1996b, 1996c; Tysdal and Moye, 1996) of the study area. For this study, the northeast end of section $A-A^{\prime}$, which appeared only on the map of Tysdal and Moye (1996), is extended about $2 \mathrm{~km}$ farther northeast into the Lem Peak quadrangle (Tysdal, 1996b) than the limit originally published. Slight modifications have been made to the deeper part of some faults in the cross sections.

In an attempt to reconstruct the structural situation prior to extensional faulting, normal displacement on faults has been removed and the sections reconstructed as shown in figures 6 and 7. Normal faults in the thrust belt of western Montana and central Idaho are known to be listric in shape, as indicated by seismic data, and those of the study area are interpreted to be listric at depth, as shown schematically in figure 3. But within the depths depicted in the cross sections (fig. 5), only a slight curvature is shown for most of the normal faults. The scale of structures in the hinterland of the Cordilleran thrust belt is large, considerably more so than to the east in the leading part of the thrust belt. The normal faults have a large radius of curvature and cut deep into the crust before flattening out. (See for example the many cross sections of Harrison and Cressman (1993) in the hinterland of the thrust belt in northwestern Montana.) Hence, in removing the normal displacement from faults, fault attitudes determined during mapping and construction of the cross sections were maintained. For the amount of 
displacement removed, fault curvature is small and was not incorporated into the reconstructions.

The normally displaced strata were moved up the fault plane until contacts of the hangingwall aligned with those of the footwall. This procedure is not as satisfactory as I would like because erosion occurred after normal displacement had taken place; hence, the restored cross sections contain a "gap" above the present ground surface of the footwall of each fault. This gap was minimized as much as possible and still allow a reasonable reconstruction. I recognize, however, that the amount of eroded rock (thus, the gap) could be considerably greater than interpreted. Downsection viewing, and projection of structure into each restored cross section, afforded some measure of control. In some cases, extensive, thick sequences of the Challis Volcanic Group were deposited on the erosion surfaces in the Eocene, thus arresting erosion of the Proterozoic bedrock. Some of the bedrock has only recently been exhumed, lessening the amount of interpreted erosion. Despite the uncertainties, the general style and magnitude of the fold are quite apparent and would not change even assuming three to four times the amount of erosion depicted in the reconstructed sections.

The diamictite unit of the Apple Creek Formation also adds uncertainty to the reconstruction of the cross sections, because it deformed plastically during folding, owing to its high content of clay and fine silt. It is isoclinally folded at least locally and overthickened in the core of the fold depicted in the restored sections, particularly in cross section $D-D^{\prime}$ (fig. 6 ). Further, the unit thins rapidly to the northwest, due to its depositional pattern. A northwest-southeast cross section, which would be normal to the interpreted tectonic transport direction of the unit, would show a lens shape, the unit thinning to both the northwest and the southeast. These characteristics are reflected in the cross sections.

\section{Poison Creek Anticline}

The reconstructed cross sections indicate that the map area in the northern part of the Lemhi Range is the hangingwall of the Poison Creek thrust fault and that the strata originally formed a very large anticline. The fold may have had a radius of as much as 10,000-12,000 m (fig. 7). Such a large fold is of a reasonable scale in the hinterland of the Cordilleran overthrust belt. For example, the cross sections of Harrison and Cressman (1993) show folds of this size in the Mesoproterozoic strata of northwestern Montana.

The now-disrupted megafold, named the Poison Creek anticline, lies above the footwall ramp of the Poison Creek thrust fault and is interpreted as a fault-propagation fold. Folds so classified are steep to overturned structures of the hangingwall of a propagating thrust fault with which they grow contemporaneously, initiating from the fault tip (Suppe, 1983, 1985). The Poison Creek fault and fold have not been traced to or near their point of zero displacement, thus this fault-fold classification is inferred. However, the fault does lack a footwall syncline, a feature that characteristically is lacking from models of "traditional" fault-propagation folds (McNaught and Mitra, 1993).
Figure 7 shows the relationship of the Poison Creek hangingwall thrust sheet to the nearly flatlying footwall strata of the McDevitt Creek sheet. In figure 7, the reconstructed hangingwall anticline of cross section $B-B^{\prime}$ shown in figure 6 is extended northeast from $B^{\prime}$ to $B^{\prime \prime}$. Strata of the Gunsight Formation exposed at the surface of the $B^{\prime}-B^{\prime \prime}$ extension are thought to be in the uppermost part of the formation; hence, the inferred Gunsight-Swauger contact is shown above the ground surface of figure 7's cross section $B^{\prime}-B^{\prime \prime}$. Concealed Swauger strata shown in the cross section are of approximately the correct thickness for the formation. Their placement in the cross section also is in agreement with their projection into the plane of section $B-B^{\prime}-B^{\prime \prime}$ from the footwall strata northeast from point $A^{\prime}$ of cross section $A-A^{\prime}$, in the McDevitt Creek sheet north of the study area. North of the study area, in the Poison Peak 7.5minute quadrangle (fig. 2), mapping by G.R. Winkler showed that footwall Gunsight strata dip $6^{\circ}-10^{\circ}$ southward for more than $10 \mathrm{~km}$ into the southern part of the quadrangle, where the Swauger-Gunsight contact is preserved and displays a similar inclination. Exposed Gunsight strata of the cross section $B^{\prime}-B^{\prime \prime}$ extension show the low dips of the Gunsight, but no Swauger strata are exposed. Within the study area, the Poison Creek sheet overlies a footwall ramp; northeastward, the footwall ramp probably gave way to a footwall-flat (now eroded), based on the gentle dips of the Gunsight strata in the footwall, as described previously.

The stratigraphic height of a ramp is approximately equal to the height of the associated fold, as measured from anticlinal crest to synclinal trough, for both fault-bend and fault-propagation folds (Jamison, 1992, p. 156). The reconstructed Poison Creek anticline has an amplitude of at least $10,500 \mathrm{~m}$. Calculation of the fold height assumes that the entire thicknesses of the Swauger $(3,100 \mathrm{~m})$ plus the banded siltite unit of the Apple Creek Formation $(1,500 \mathrm{~m}$ ) (table 1) were present at the time of thrusting but now are eroded from the Poison Creek sheet within the Lemhi Range. Along the trace of the Poison Creek thrust fault in the Lemhi Range, upper strata of the coarse siltite unit of the Apple Creek are in thrust contact above Paleozoic strata as young as the Middle Ordovician to Lower Silurian Saturday Mountain Formation. Consequently, the Poison Creek thrust fault has cut upsection about 7,500 $\mathrm{m}$ through the hangingwall rocks. This makes for a discrepancy of about 3,000 $\mathrm{m}(7,500 \mathrm{~m}$ versus $10,500 \mathrm{~m}$ ) between the fold estimate and the demonstrable stratigraphic displacement across the Poison Creek fault. The difference, or a large part of it, may be reconciled by addition of the stratigraphic displacement on the subsidiary thrust faults to the $7,500 \mathrm{~m}$. Further, the $10,500 \mathrm{~m}$ figure is not an anticlinal-crest-to-synclinal-trough measurement-that distance must be considerably greater than $10,500 \mathrm{~m}$.

\section{Relationship of Poison Creek Anticline and Basin Lake Syncline}

The Basin Lake syncline occurs between the Poison Creek thrust fault and the Bear Valley fault. The syncline, discussed previously, was interpreted as part of a compressional 
fold-couple related to the Bear Valley fault, formed prior to normal displacement on that fault. Three explanations for the occurrence of the syncline adjacent to the Poison Creek fault are considered.

1. The syncline formed in the hangingwall of the thrust sheet during regional compression. In discussing fault-propagation folding, Suppe and Medwedeff (1990, p. 422) reported that it is particularly common for a thrust fault to break through strata at an angle that is less than the dips of the synclinal and anticlinal axial surfaces, illustrating the observation with a syncline in the leading part of the hangingwall of the Absaroka thrust fault of southeastern Idaho. Similarly, Mitra (1990, p. 933) stated that the occurrence of a syncline in the hangingwall or the footwall of a thrust fault depends on whether the fault propagated through the footwall or the anticlinal forelimb (Mitra, 1990, p. 933), and that a syncline may be transported as part of the hangingwall of the thrust sheet - a translated faultpropagation fold. Building on the observations of these authors, I suspect that the Basin Lake syncline may have formed early in the developing compressional deformation of the area. Once the anticline and syncline of the fold-couple associated with the Bear Valley fault had formed, minor compressional displacement ceased on the Bear Valley fault. The Poison Creek thrust fault then splayed from near the base of the Bear Valley fault as a thrust imbricate, which proceeded to develop into a major thrust fault that propagated northeastward along beds of the southwest-dipping limb of the Basin Lake syncline. With this scenario, the syncline would be preserved within the hangingwall of the Poison Creek thrust fault.

2. Subsequent to thrusting, normal displacement on the Poison Creek fault occurred, which accentuated the Basin Lake syncline. This possibility can be evaluated only in the northwestern part of the study area, where bedrock is widely exposed in both the hangingwall and footwall of the Poison Creek thrust fault. No direct evidence of back-slip (normal displacement) was found during fieldwork, although some amount of back-slip cannot be ruled out. This explanation requires that the northeast limb of the syncline steepened its southwest inclination during rotation, and that mesoscopic folds and axial-plane cleavage of the limb also were rotated. Axial planes of mesoscopic folds and the related cleavage in the Apple Creek Formation of the hangingwall adjacent to the thrust fault dip southwest and are about coplanar with the plane of the fault; this suggests that rotation of the hangingwall limb of the syncline is not significant.

3. An unrecognized normal fault lies between the Poison Creek thrust fault and the axis of the Basin Lake syncline. Bedrock widely exposed between the Poison Creek thrust fault and the axis of the Basin Lake syncline (fig. 4), entirely of the coarse siltite unit of the Apple Creek Formation, contains areas of limited exposure south of Phantom Creek in which a normal fault could be present but unrecognized. (The fault, if it exists, is not shown in fig. 4 or in cross section $A-A^{\prime}$ of fig. 5.) Such a normal fault likely would have curved at depth and merged with the Poison Creek thrust fault. This possibility would permit accentuation of the syncline and normal displacement on much of the Poison Creek thrust fault.

Possibility (1), a hangingwall fold, is favored here. Possibility (2), back-slip on at least the exposed part of the Poison Creek thrust fault, appears to be least likely. Possibility (3), an unrecognized normal fault south of Phantom Creek, could exist. Two directions of movement on the Poison Creek fault are indicated in the cross sections, to accommodate at least some normal displacement on the Poison Creek thrust fault. The double symbol also illustrates the widespread occurrence of extensional movement on thrust faults subsequent to compressional deformation in the study area and regionally.

\section{Intersection of Hayden Creek and Bear Valley Faults}

The Hayden Creek and Bear Valley faults join in the northwestern part of the map area (fig. 4), vicinity of cross section $A-A^{\prime}$ (fig. 5). The fault pattern in the cross section is much simplified from that shown by Tysdal and Moye (1996). A possible configuration of faults prior to normal displacement, along with a related fold, is shown in figure 9 and is interpreted in this section.

North of the Bear Valley fault, and west of cross section line $A-A^{\prime}$ (fig. 4), bedding and folds, including the Basin Lake syncline, trend westerly in concert with the westerly strike of the Bear Valley fault. These footwall structures related to the Bear Valley fault are in structurally low strata of the anticline/ syncline fold-couple. South of the Bear Valley fault (and west of cross section line $A-A^{\prime}$, fig. 4), beds strike northwest and are cut off by the Bear Valley fault. These hangingwall structures related to the Bear Valley fault are a structurally high part of the fold-couple, even though they may be topographically lower, and trend northwest in contrast to the westerly trends of the footwall strata. Figure 9 shows an interpreted fold-couple with progressively increasing deformation toward the west. Hangingwall strata have been moved up the Bear Valley fault to their interpreted pre-normal-slip position. Down-to-the-south normal-slip on an incipient Bear Valley fault (dashed in fig. 9), which trends about parallel to the synclinal axis, would leave northwest-striking rocks on the south juxtaposed against westerly-striking rocks (including overturned beds) on the north, much as shown in figure 4. An incipient Hayden Creek normal fault is shown on the west side of the Bear Valley fault.

Interpretation of the fault pattern shown in cross section $A$ $A^{\prime}$ (fig. 5) assumes that the Hayden Creek and Bear Valley faults formed originally as compressional features, but that offset of the fold-couple was minor. Figure 9 shows how these faults may have appeared just prior to normal-slip during extensional failure of the nose area of the anticline of the fold-couple. Minor thrust displacement that is suspected to have taken place on these faults prior to normal-slip is not shown in the illustration-any such thrust displacement has been removed by backslip to the positions depicted in the reconstruction illustrated. The interpretive cross section is speculative, of course, because the pre-faulting rocks have been eroded; down-structure relationships are not available for projection into a cross-sectional plane to aid the reconstruction.

\section{Normal-Slip on Bear Valley Fault}

Normal-slip on the Bear Valley fault developed along the overturned segment of the anticlinal limb of the fold-couple. 


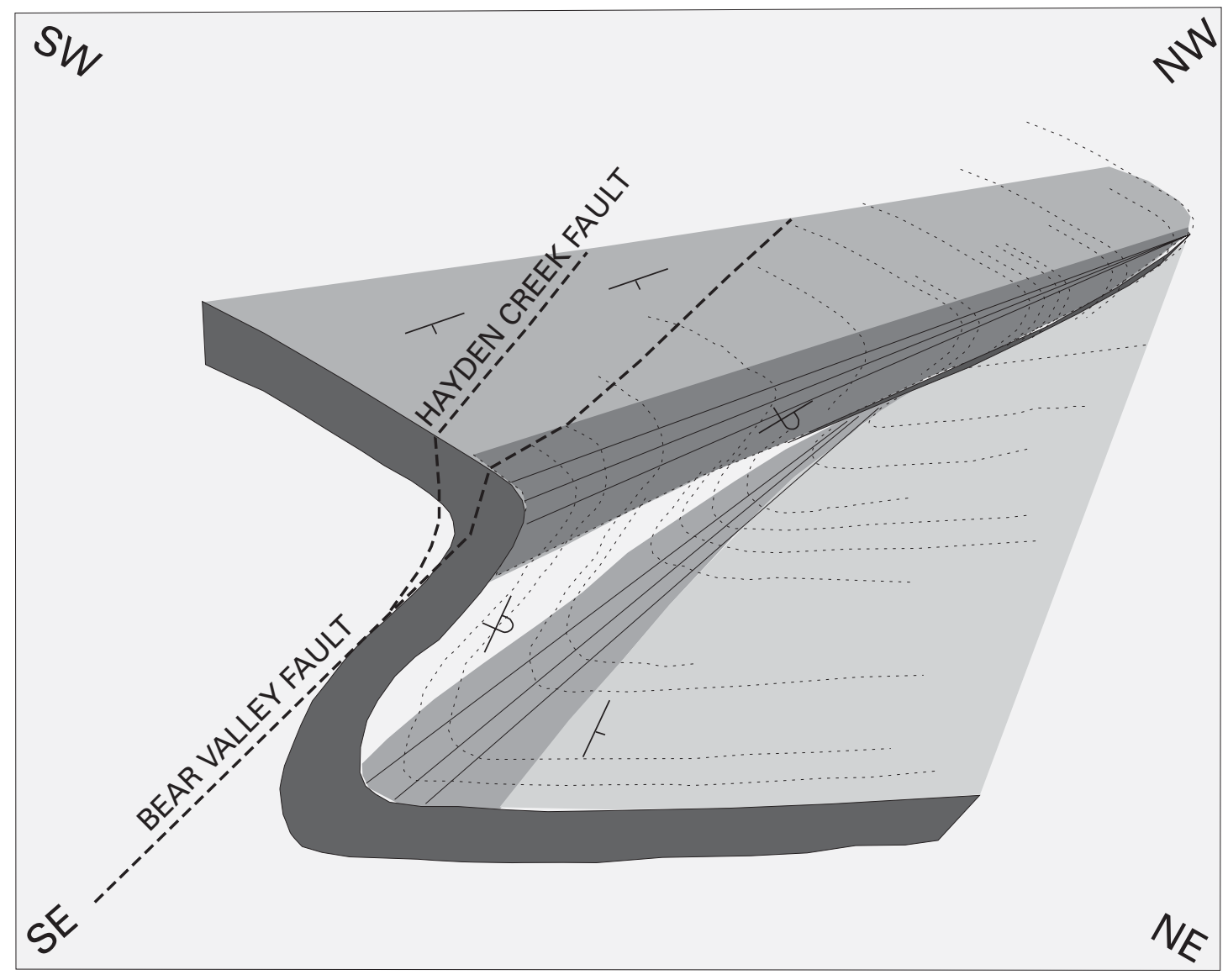

Figure 9. Diagrammatic sketch of fold and incipient faults interpreted to have existed just prior to normal displacement on the Hayden Creek and Bear Valley faults, cross section $A-A^{\prime}$ in northwestern part of study area. Strike and dip symbols show areas of right-side-up and overturned beds. Dotted lines are used to emphasize shape of fold. See text for explanation.

The overturned segment is present (or was present) in the northwestern part of the study area (west of Basin Lake, fig. 4). Along the central extent of the fault (southeastern part of Lem Peak quadrangle and northern part of Mogg Mountain quadrangle, fig. 2), the anticlinal limb becomes vertical or dips steeply to the northeast. But the fault maintained the southwestward inclination and permited down-to-the-south(west) displacement of hangingwall strata of the Bear Valley subsheet.

When rock of the Bear Valley subsheet east of the Payne Creek fault (figs. 3, 4) is moved northeast, into restored fold position (just before the fold was broken along the Bear Valley fault), normal-slip on the fault appears to have initiated along overturned diamictite strata of the Apple Creek Formation in the steepest part of the common limb of the foldcouple. In the area of Hayden Creek, the estimated minimum normal-slip displacement of the Bear Valley subsheet is $4 \mathrm{~km}$ east of the Payne Creek fault and about $5.5 \mathrm{~km}$ west of it. My impression is that displacement on the Bear Valley fault in the Hayden Creek area may be greater than that in the Basin Lake area; thus, the Basin Lake area is a pivot area for the Bear Valley subsheet.

\section{Intersection of Structures in Northwestern Part of Map Area}

The overall pattern of compressional faults and folds shows a convergence toward the northwest, toward the Poison Creek thrust fault (figs. 3, 4). The Bear Valley and Hayden Creek faults, and the Basin Lake syncline, all strike at a small angle to the Poison Creek thrust. This is the case even after normal displacement has been removed from the Bear Valley and Hayden Creek faults and the strike of the structures is adjusted for the Hayden Creek fault cutting downsection to the northwest. (1) One possible cause of the convergence is slightly oblique transport of the Poison Creek sheet over the footwall rocks, resulting in formation of the Bear Valley and Hayden Creek faults. (2) Another possibility is a northwestward steepening of the Poison Creek thrust fault toward the northwest due to the existence of resistant Ordovician dolomite and quartzite in the footwall (McDevitt Creek sheet). In either case, the oldest rocks of the Poison Peak sheet are exposed closer to the fault in the northwestern part of the map area because they moved farther up the thrust plane there than strata to the southeast. 


\section{Stereonet Data}

Stereonet data were plotted to aid interpretation of the compressional history of the study area. The central Idaho region underwent compression during Cretaceous orogeny, but Mesoproterozoic compressional deformation also has been reported (for example, Evans, 1986; Evans and Zartman, 1990). A goal of the geologic mapping and structural studies was to collect sufficient data to determine if rocks of the study area had undergone more than one compressional deformation. Bedding and cleavage elements were compiled for each of the structural sheets, the subsheets, and the block shown in figure 3 .

Structural data from all subsheets of the Poison Creek thrust sheet were compiled into one data set each for bedding and for cleavage, permitting comparison of data from an individual subsheet with that of other subsheets and with that for the entire thrust sheet (figs. 10,11). Cleavage data from the part of the McDevitt Creek thrust sheet directly north of the trace of the Poison Creek thrust fault also are shown in a stereoplot and compared with data from the Poison Creek thrust sheet. Data from the Lem Peak block are considered only in a general way because (1) the block has only sparse observations, (2) data exist mainly for the leading area of the block, and (3) the block underwent a large amount of normal-slip displacement that may have been accompanied by a significant component of rotation of the block or parts of it.

In the initial stages of data compilation and analysis, stereoplots of bedding and cleavage were constructed for each individual formation and formational unit within each sheet and subsheet. The compiled data showed that structural orientations for these individual formations were virtually identical with those for the aggregate of all formations and rock units within each sheet or subsheet. Hence, only stereoplots of the aggregated data are presented (except for fig. 11E, $F$ ). Bedding for the Poison Creek sheet and subsheets is shown in figure $10 A-D$, and cleavage for the sheet and subsheets is shown in figure $11 A-$ $D$. An exception is made for cleavage data from the diamictite unit of the Apple Creek Formation, which is shown in the stereoplots of figure $11 E-H$. These data are illustrated because the diamictite recorded cleavage more readily than did the other Proterozoic rock units, probably because of its generally finer grain size, and would be more likely to preserve structural elements of more than one compressional event, should more than one have taken place. Cleavage data for lower Paleozoic carbonate strata in the rearward part of the McDevitt Creek sheet are shown in the stereoplot of figure 11J. This data set is compared with the cleavage measured in the Mesoproterozoic rocks in the northeastern part of the directly overlying Poison Creek thrust sheet (that is, the northeastern part of the Basin Lake subsheet), shown in figure $11 \mathrm{~K}$.

\section{Bedding}

Bedding data for each lithology and each thrust sheet show a high degree of consistency of orientation properties among the different rock types within each subsheet, and among the different subsheets. Poles to bedding for the Poison Creek thrust sheet (fig. 10A) depict a girdle distribution oriented northeast-southwest. This pattern reflects the broad, overall shape of the forward part of the large anticline reconstructed by removing the normal displacement from the Hayden Creek and Bear Valley faults (fig. 7). The concentration of data points in the southwest quadrant reflects the generally steep-to-the-northeast dips characteristic of all three subsheets that are a part of the Poison Creek anticline. Beds of the Hayden Creek subsheet (fig. 10B) all dip steeply. Beds of the Bear Valley subsheet (fig. 10C) show a girdle distribution that records the many small anticlines and synclines formed in the argillite and argillaceous siltite of the diamictite unit of the Apple Creek Formation. These small folds formed in the footwall of the Hayden Creek fault and formed in the same stress field that formed the larger Poison Creek anticline. Beds of the Basin Lake subsheet (fig. 10D) show a range of dips from vertical to nearly horizontal, a distribution reflecting the low to moderate dips of the Basin Lake syncline as well as the steep dips in the footwall of the Bear Valley fault.

The plot of poles to bedding for the Bear Valley and Basin Lake subsheets displays a fairly narrow belt (girdle) of poles to bedding (fig. $10 C, D$ ). The concentration of data points in the Hayden Creek subsheet does not show a girdle distribution, but the concentration of data points lies within the girdles defined in the other two subsheets. This is well shown in the girdle distribution for the Poison Creek thrust sheet as a whole (fig. 10A). None of the diagrams of bedding is suggestive of more than one orientation of stress field. Some individual plots have somewhat more scatter of poles than composite diagrams for each subsheet or for the three subsheets combined, but this is only for a few poles at the 1 percent contour interval used.

\section{Cleavage}

Cleavage data for the Poison Creek thrust sheet and for each lithology within the sheet show a high degree of consistency of orientation properties among the different rock types within each subsheet, and among the different subsheets. Poles to cleavage for the Poison Creek thrust sheet (fig. 11A) depict a point maxima in the northeast quadrant, which becomes diffuse toward the northeast limit of the quadrant. This pattern reflects the consistent northwest strike of cleavage and abundance of $30^{\circ}-60^{\circ}$ dips to the southwest. The cleavage of each subsheet differs somewhat in its steepness of dip. This likely reflects (1) that the subsheets constitute different parts of the megafold. The subsheets are now juxtaposed along faults that display significant normal displacement, but the structures within the subsheets were formed when the subsheets were in structural positions different from those where they now reside. (2) The differing steepness of dip of cleavage among the subsheets also probably reflects the tendency of cleavage to become asymptotic to thrust faults. This is particularly true for rocks in the vicinity of cross section $B-B^{\prime}$ (fig. 5), where the cleavage becomes shallower at depth as the Bear Valley fault is appoached. In general, the shallowest dipping cleavage is in the footwall of the Bear Valley fault (Basin Lake subsheet) and in the overturned strata of the anticline/syncline fold-couple of the Bear Valley and Basin Lake subsheets. The dips are mostly in 


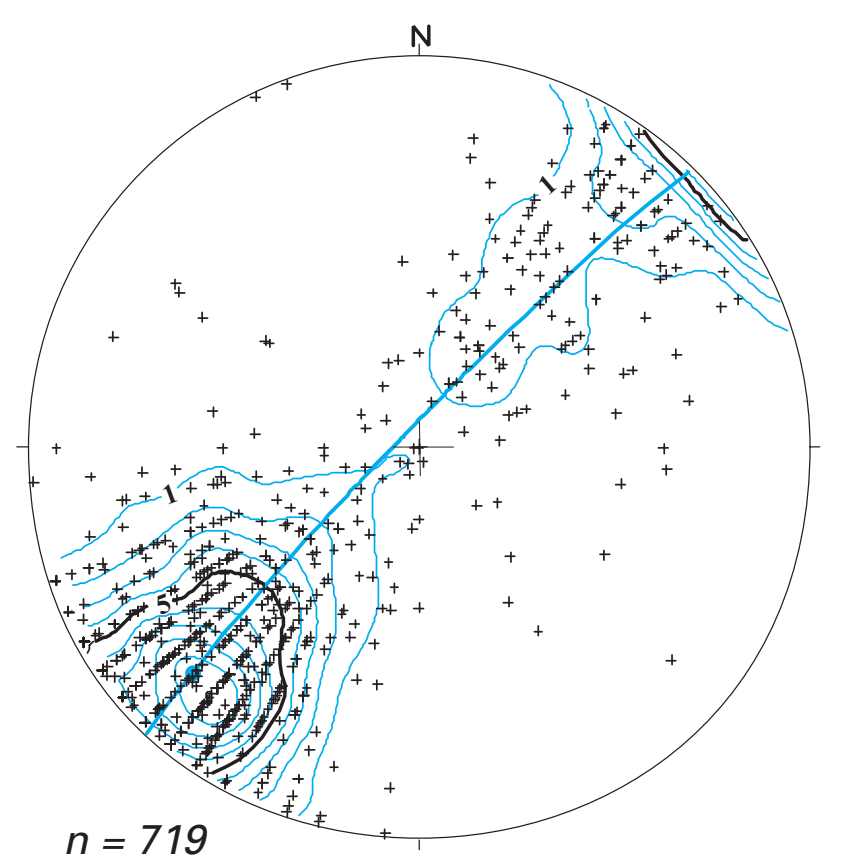

A Poison Creek sheet-bedding (all rock units)

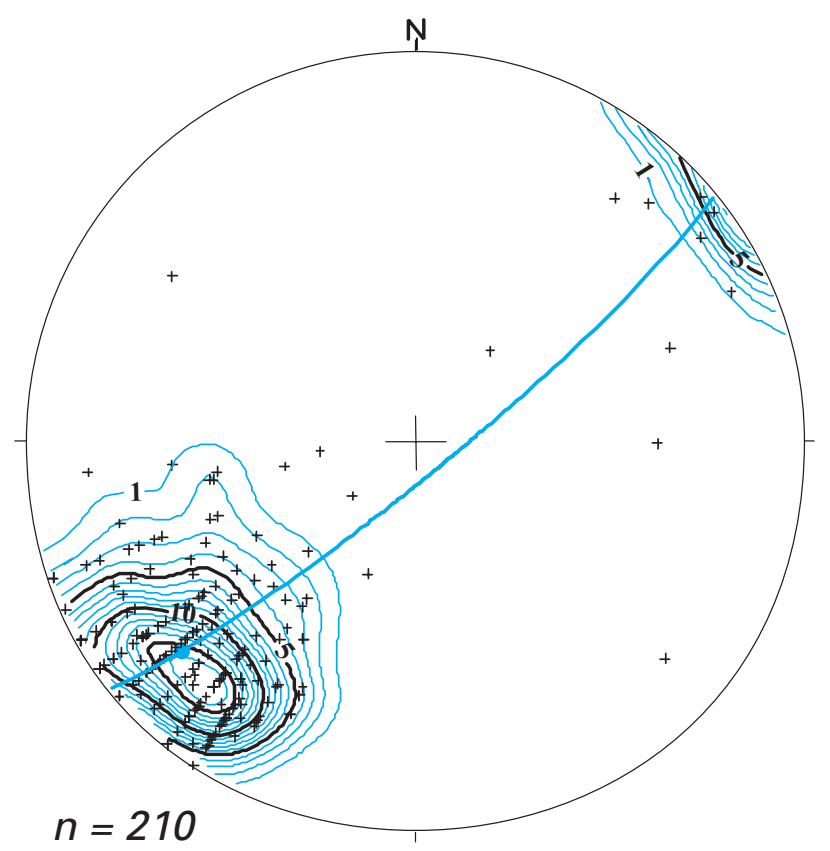

B Hayden Creek subsheet-bedding (all rock units)

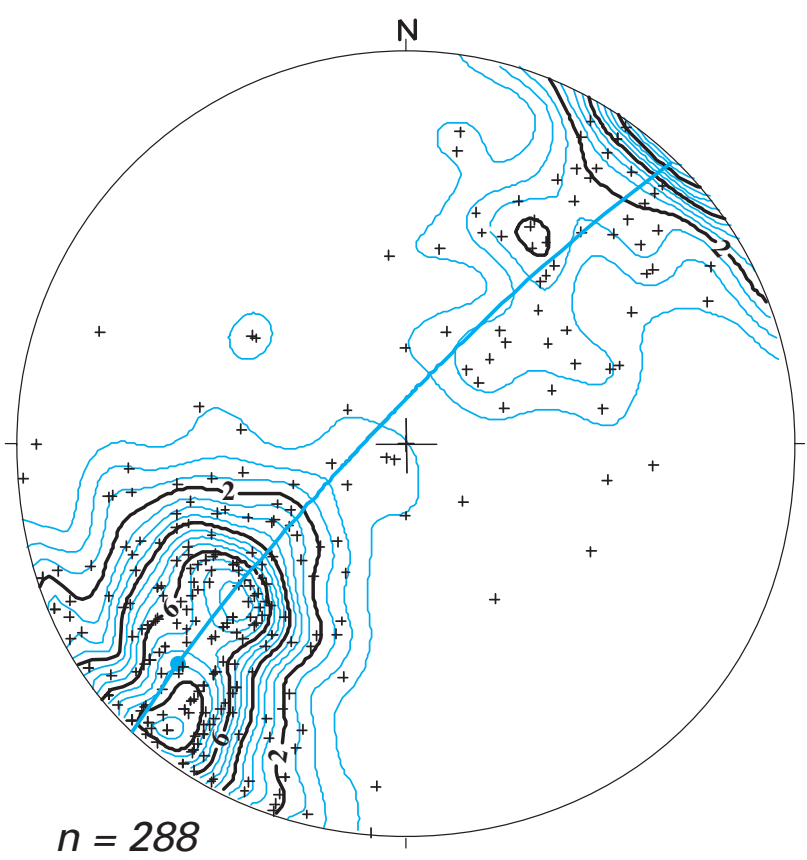

C Bear Valley subsheet-bedding (all rock units)

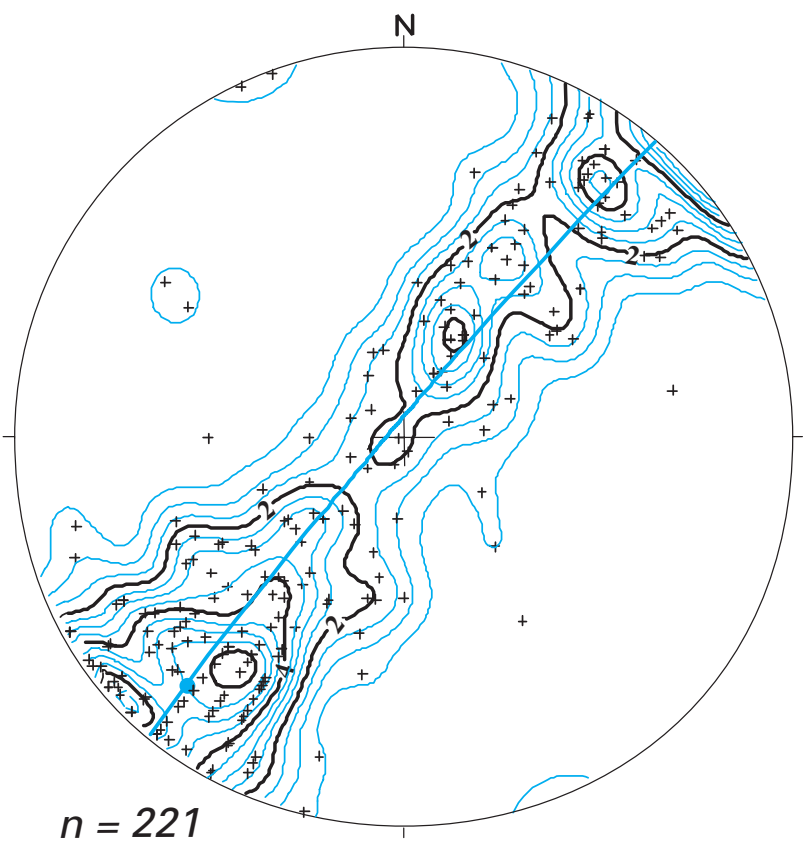

D Basin Lake subsheet-bedding (all rock units)

Figure 10. Stereonet plots of bedding. Views $A-D$ are discussed in text and identified in figure for visual clarity.

the $25^{\circ}-35^{\circ}$ range. Steeper dips are common in the upright part of the anticline of the fold-couple, throughout most of the Bear Valley subsheet and the remainder of the study area. These observations are in agreement with findings of Mitra and Elliott (1980) that cleavage within a thrust sheet can be followed downward and is asymptotic to the thrust plane, suggesting that thrusts approximate planes of maximum shearing strain.

Poles to cleavage of the Hayden Creek subsheet (fig. 11B) are highly focused about a point maxima in the northeasternmost part of the northeast quadrant. The poles record steep dips $\left(70^{\circ}-\right.$ $90^{\circ}$ ) of cleavage to the southwest. The cleavage is mostly recorded from the Big Creek Formation (Yb, fig. 4). Poles to cleavage of the Bear Valley subsheet (fig. 11C) show two point maxima, in part a combination of the point maxima depicted for the Hayden Creek and Basin Lake subsheets. Poles to cleavage of the Big Creek Formation and the fine siltite of the Apple Creek Formation are most common in the point maxima nearest the center of the diagram. Poles to cleavage of the diamictite 


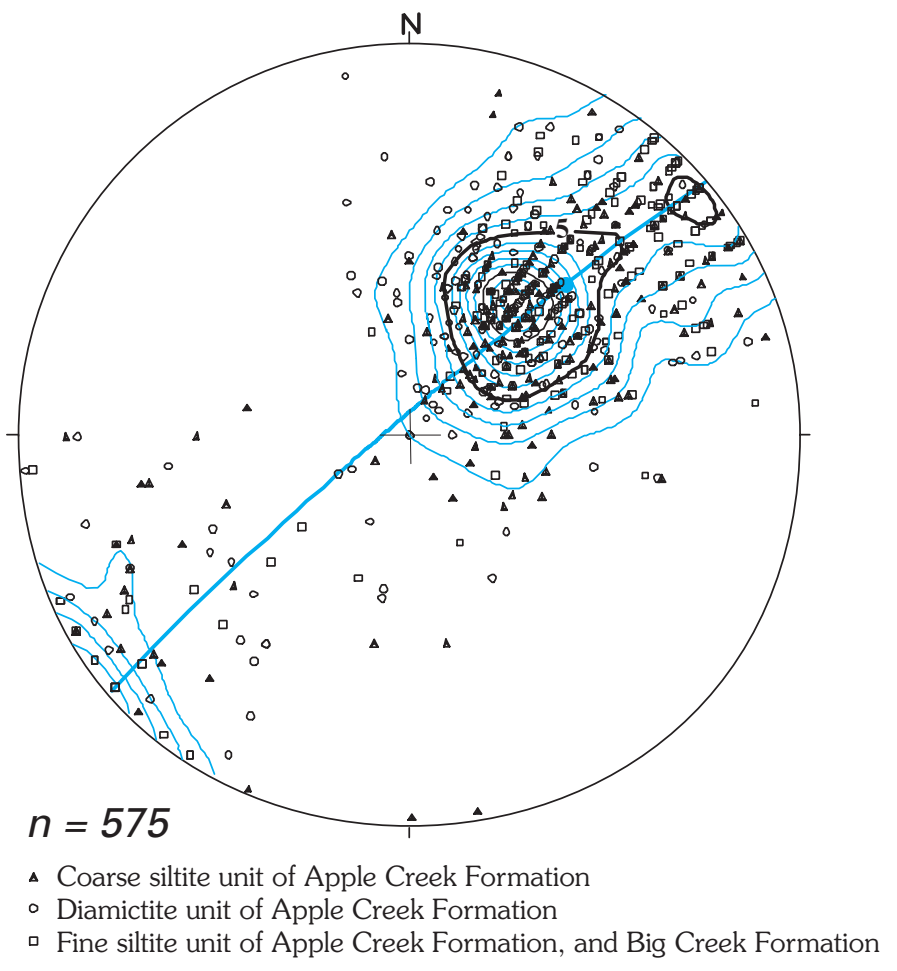

A Poison Creek sheet-cleavage (all rock units)

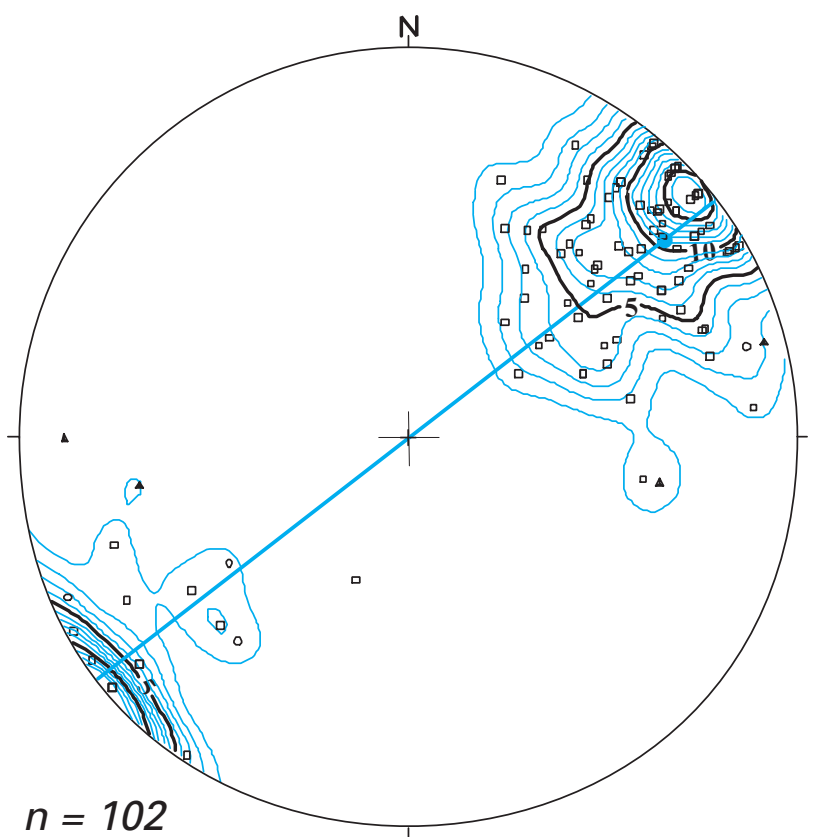

$\Delta$ Coarse siltite unit of Apple Creek Formation

- Diamictite unit of Apple Creek Formation

- Fine siltite unit of Apple Creek Formation, and Big Creek Formation

B Hayden Creek subsheet-cleavage (all rock units)

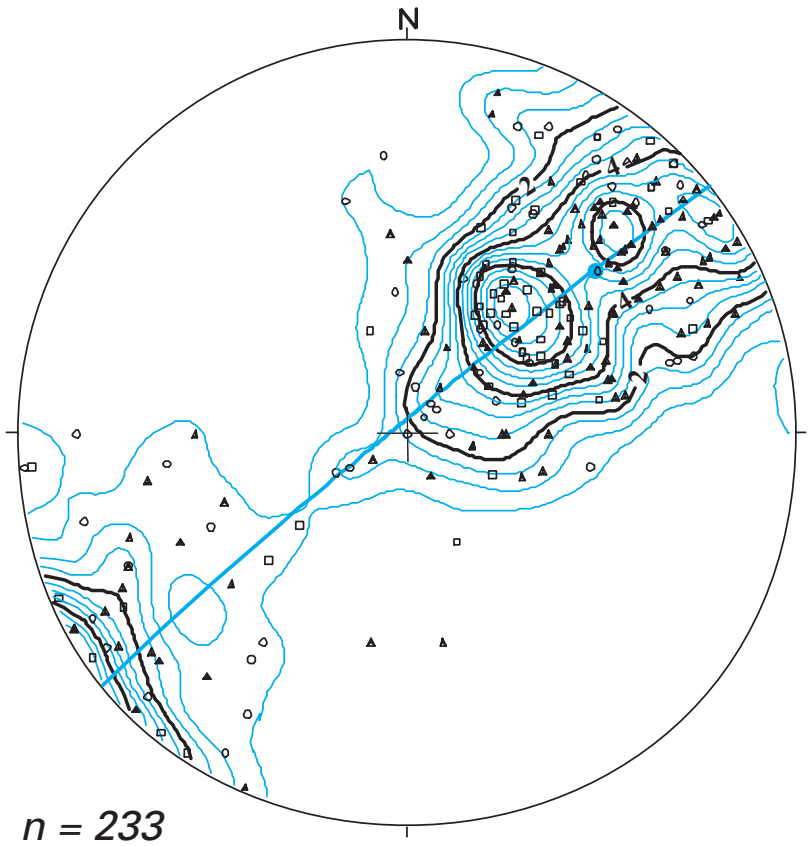

$\Delta$ Coarse siltite unit of Apple Creek Formation

- Diamictite unit of Apple Creek Formation

- Fine siltite unit of Apple Creek Formation, and Big Creek Formation

C Bear Valley subsheet-cleavage (all rock units)

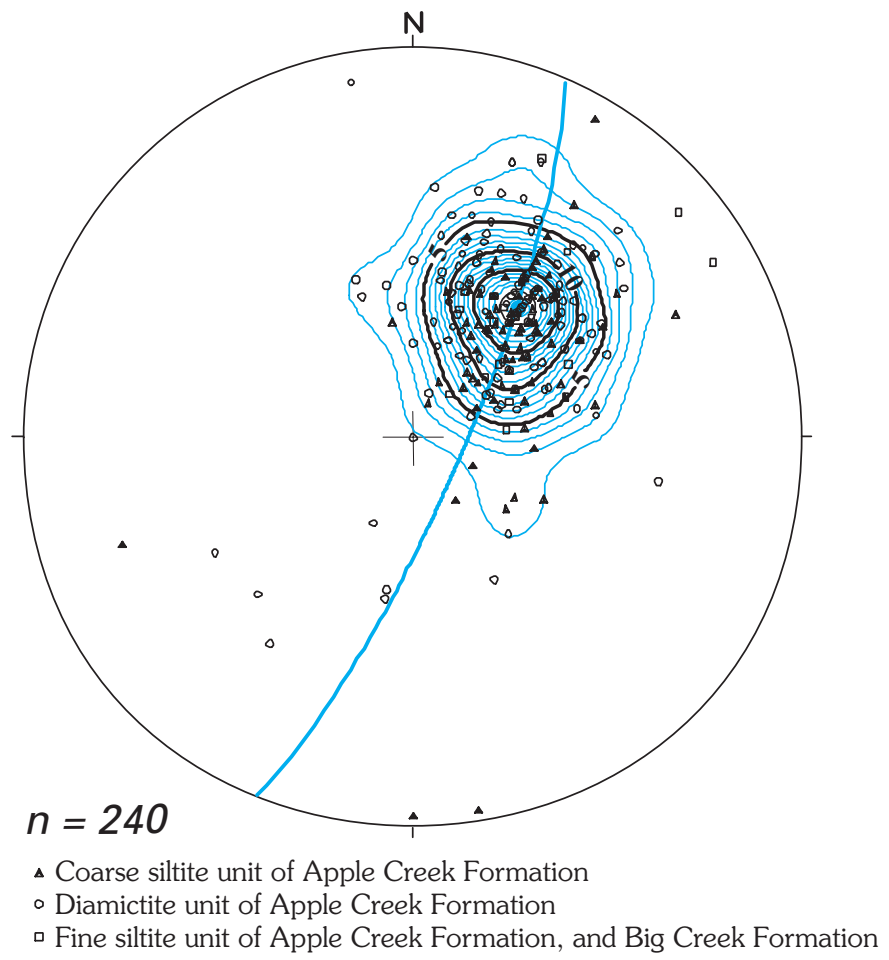

D Basin Lake subsheet—cleavage (all rock units)

Figure 11 (above, facing page, and overleaf). Stereonet plots of cleavage. Views $A-K$ are discussed in text and identified in figure for visual clarity. There is no stereonet plot for the letter $l$.

unit of the Apple Creek are most common in the point maxima near the outer part of the quadrant, reflecting steeper dips of cleavage. However, poles of the diamictite also range into the area of the more central point maxima. Poles to cleavage of the coarse siltite unit of the Apple Creek are approximately of the same concentration in the area of both maximas. Poles to cleavage in the Basin Lake subsheet (fig. 11D) show a bullseyepattern point maxima in the northeast quadrant. Southwest dips 


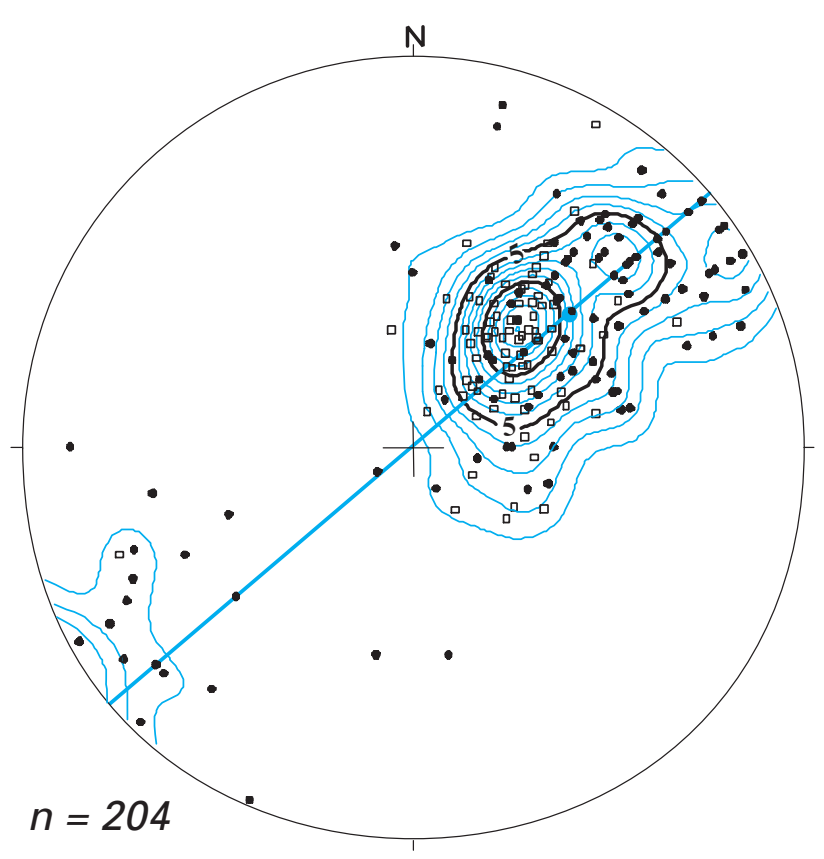

- Bear Valley subsheet

- Basin Lake subsheet

E Bear Valley and Basin Lake subsheets-unrotated cleavage (for all stations in diamictite unit of Apple Creek Formation)

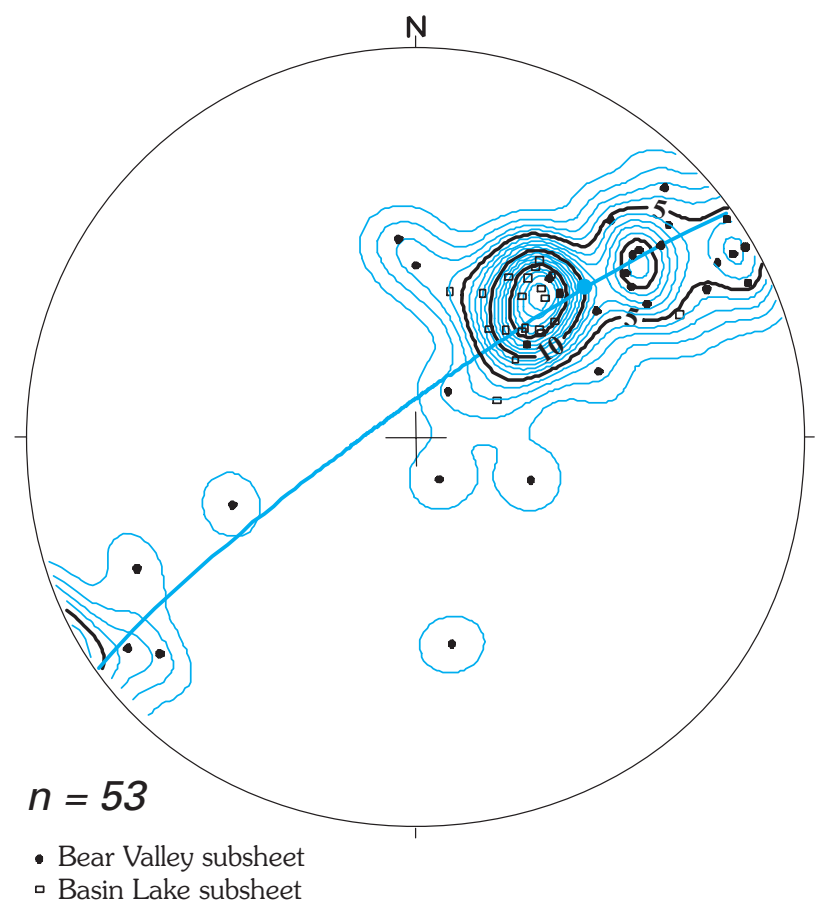

F Bear Valley and Basin Lake subsheets-unrotated cleavage (for 53 selected stations in diamictite unit of Apple Creek Formation)

are in the range of $30^{\circ}-60^{\circ}$. Strata from which these data were obtained include all units of the Apple Creek Formation, but none from the Big Creek Formation. Poles to cleavage for each of the three units of the Apple Creek Formation are intimately mixed within the point maxima, such that the poles to cleavage

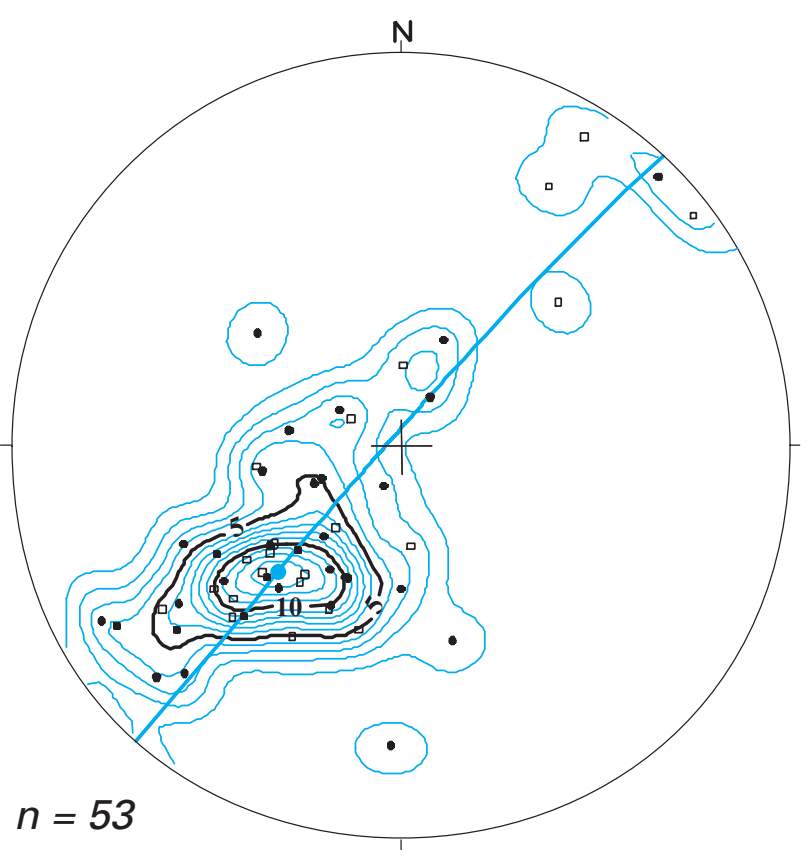

- Bear Valley subsheet

- Basin Lake subsheet

G Bear Valley and Basin Lake subsheets_rotated cleavage (for 53 selected stations in diamictite unit of Apple Creek Formation)

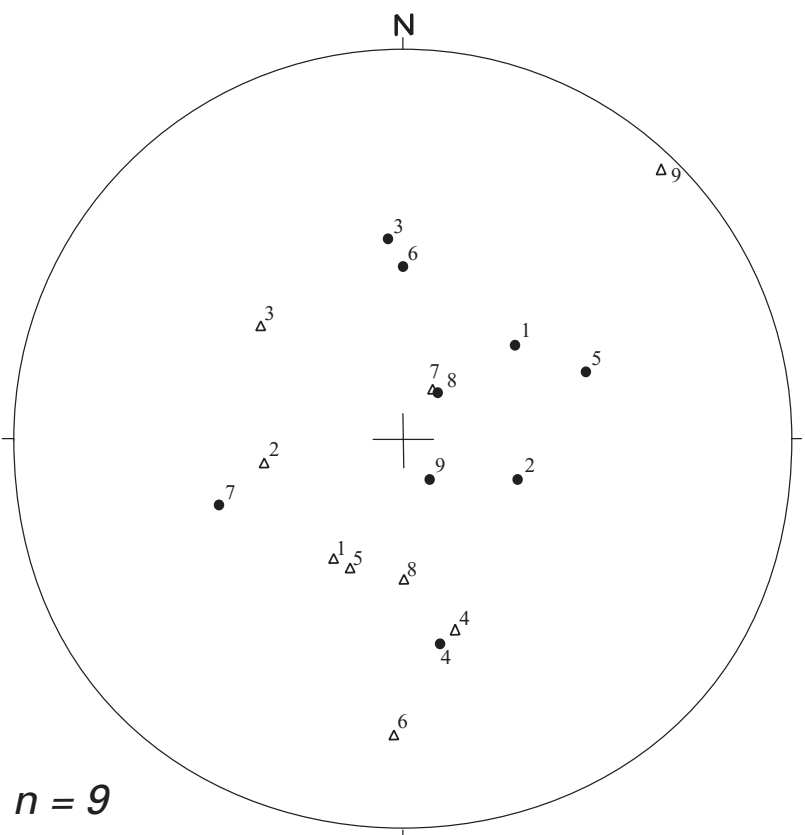

- Unrotated cleavage

$\triangle$ Rotated cleavage

H Bear Valley subsheet-rotated and unrotated cleavage (for 9 of 53 selected stations in diamictite unit of Apple Creek Formation); numbers show individual data points before and after rotation

of any one of the rock units would define very nearly the same point maxima.

The foregoing data, however, suggest that lithology exerts some control on the dip of cleavage in the different thrust sheets. Diamictite, with its finer grain size of argillite to fine silt, 


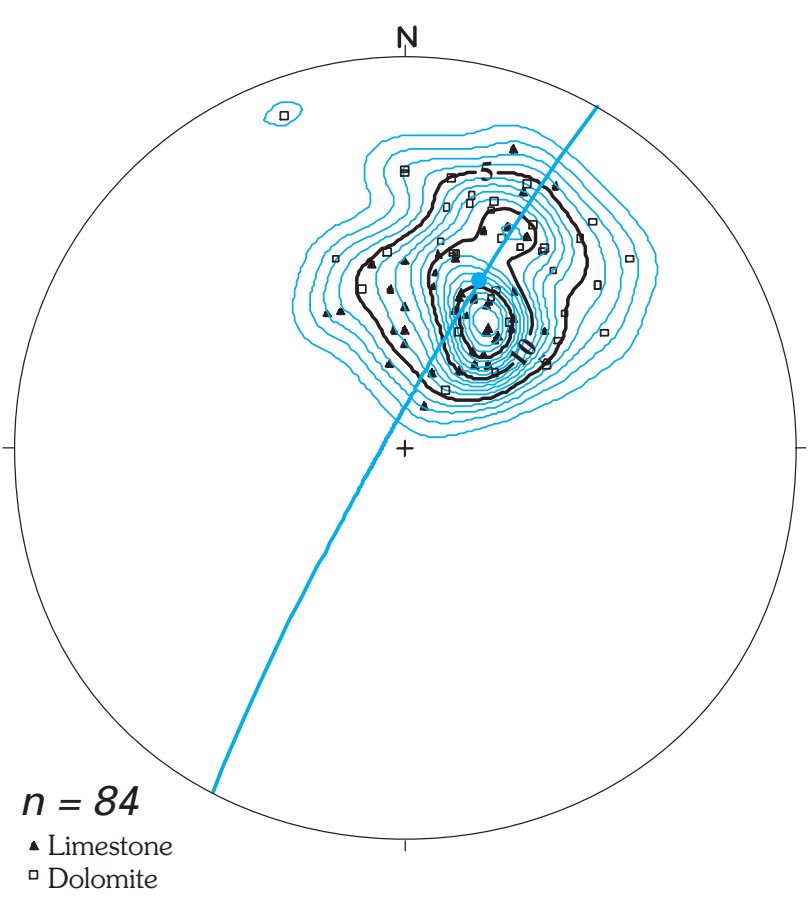

J McDevitt Creek sheet-cleavage (Paleozoic carbonate rocks)

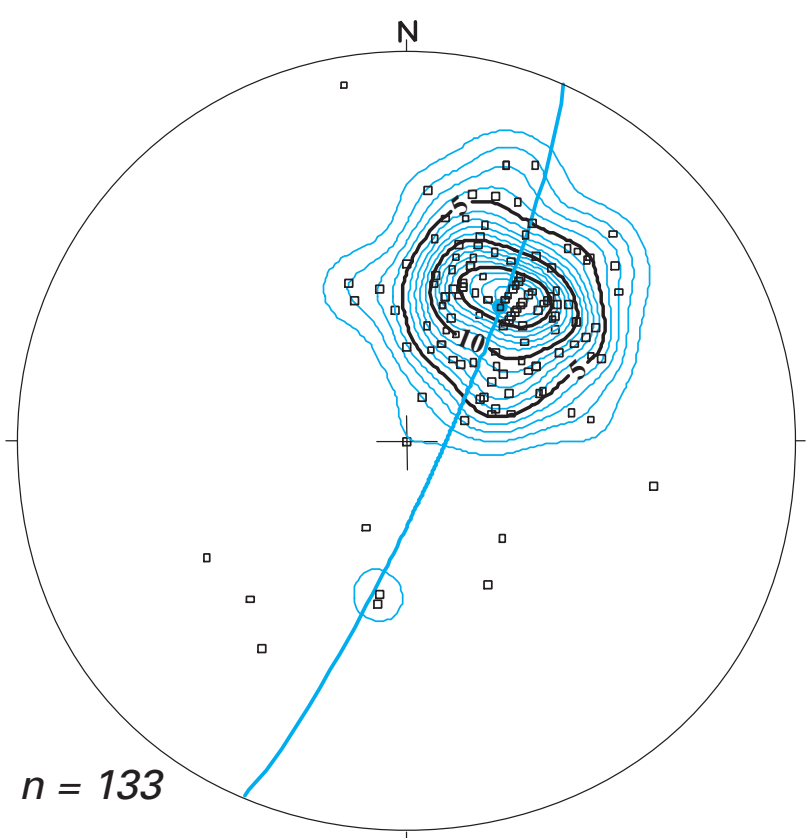

K Basin Lake subsheet, leading part-cleavage (coarse siltite unit of Apple Creek Formation)

Figure 11-Continued. Stereonet plots of cleavage.

deformed more readily than the coarser grained rocks. This is also indicated by the intensely developed cleavage within the fine strata of the diamictite unit, whereas interbeds of coarsegrained siltite to fine-grained metasandstone are not so well cleaved. The argillite and fine siltite tend to flow to relieve stress, facilitating development of steeply inclined cleavage. None of the diagrams of poles to cleavage is suggestive of more than one general orientation of stress field of deformation.

\section{Cleavage in Diamictite}

The diamictite unit of the Apple Creek Formation recorded cleavage more readily than did the other Proterozoic rock units, probably because of its generally finer grain size. For this reason, the diamictite unit was selected for further study because it would be more likely to preserve structural elements of more than one compressional event, should more than one have taken place. Nearly all the diamictite of the study area occurs within the Bear Valley and Basin Lake subsheets, which are separated by the Bear Valley fault (fig. 4). With respect to the Bear Valley fault, cleavage of the Bear Valley subsheet primarily is in the hangingwall anticline, that of the Basin Lake subsheet in the footwall syncline. Diamictite crops out mainly in the southeastern part of the mapped limits of the Basin Lake subsheet, directly beneath the Bear Valley fault (fig. 4). (Diamictite is concealed beneath Quaternary sediments and Tertiary volcanic rocks in much of the subsheet.) The data reflect a concentration of observations from the Hayden Creek area, owing to the good exposures of tightly folded rocks and to the interbeds from which bedding attitudes could be measured. Interbeds were more difficult to find in other outcrop areas of the diamictite unit of the subsheet. In contrast, cleavage in diamictite of the Bear Valley subsheet is representative of much of the length of the hangingwall anticline owing to the extensive exposures of the subsheet.

The distribution of poles to cleavage for the diamictite (fig. $11 E$ ) is a pattern expected for progressive southwest-to-northeast rollover. A more uniform northeast-southwest spread of cleavage dips might be expected, but the strata of the Bear Valley subsheet represent mainly the steeply dipping to overturned forelimb of the anticline and those of the Basin Lake subsheet represent mainly the steep southwestern part of the syncline. The remainder of the anticline has been eroded, and the moderately dipping part of the syncline is covered by volcanic rocks and Quaternary sediments.

\section{Interpretation of Cleavage in Diamictite}

Cleavage in the diamictite unit shows no readily apparent consistent geometric relationship to bedding orientation, as would be expected if cleavage formed prior to folding. The general approach leading to this conclusion is presented in the following paragraph, with a more detailed presentation and interpretation following.

An examination was made of stereoplots of poles to cleavage for which both cleavage and bedding orientations were obtained from the same outcrop of the diamictite unit. The poles to cleavage were plotted for the 53 stations that yielded both bedding and cleavage data. Poles to cleavage as recorded in the field for these stations are displayed in figure $11 F$. The poles to cleavage for each of the 53 beds were then plotted after the corresponding bed was rotated to horizontal (and upward facing), shown in figure $11 G$. The rotated data show two domains, representing the anticlinal and synclinal limbs present in the two subsheets. In both domains, poles to cleavage are broadly distributed along a northeast-southwest trend, 
indicating the general northwest strike of cleavage, and are most abundant in the southwest quadrant (fig. 11G). Cleavage dips range across a spectrum from nearly vertical to nearly horizontal, a pattern that is not consistent with uniform layer-parallel shear developed prior to folding. This unfolding of beds and cleavage to determine if cleavage revealed a prior deformation does not adjust for fold plunge, which is $0^{\circ}-10^{\circ}$ in the map area. The unfolded cleavage would not reveal deformations other than the prefolding that it was designed to determine. Because the cleavage strikes northwest, both in outcrops and in each bed after being rotated to horizontal, the strata are unlikely to have undergone a deformation wherein an axis of folding deviated significantly from a northwest trend.

The comparison of stereoplots of poles to cleavage as measured in the field (that is, unrotated) was made for the 53 stations (fig. $11 F$ ) with the same beds after they were individually rotated (about their respective strikes) to horizontal (fig. 11G). The distribution pattern of poles is similar in the two figures, except that the concentration of poles occurs in opposing quadrants.

The unrotated poles to cleavage (fig. $11 F$ ) clearly show two point maxima: one is for the domain of the anticlinal limb on the Bear Valley subsheet, the other for the synclinal limb on the Basin Lake subsheet. Figure $11 F$ shows much the same pattern as the 204 poles of figure $11 E$, which contains all the cleavage observations recorded from the diamictite of both subsheets. (The 53 poles to cleavage shown in fig. $11 F$ and $G$ are a subset of these 204 poles.)

The plots of unrotated poles (fig. $11 F$ ) and rotated poles (fig. 11G) are quite similar, but only in appearance, not in substance. The plot of cleavage as recorded in the field (fig. $11 F$ ) shows that the 21 stations of the Basin Lake subsheet define a point maxima of highly concentrated poles in the northeast quadrant. Poles to cleavage of the 32 stations of the Bear Valley subsheet form a diffuse point maxima, also in the northeast quadrant but with a few poles in the southwesternmost part of the southwest quadrant. The diffuse point maxima is northeast of the point maxima of the Basin Lake subsheet. The diffuse maxima is defined by about 3/4 of the stations of the Bear Lake subsheet; poles to the other $1 /{ }_{4}$ of the stations are distributed across the diagram.

The same 53 rotated poles to cleavage (fig. 11G) show a similar contour pattern. But the 21 data points of the Basin Lake subsheet are now spread fully across the diagram. The distribution indicates cleavage planes that have dips ranging from $0^{\circ}$ to $90^{\circ}$, and the full range of dips inclined to both the northeast and the southwest. This clearly is not indicative of uniform layerparallel shear. The 32 poles to cleavage of the Bear Valley subsheet (that is, after rotation) (fig. 11G) are mostly present in the southwest quadrant. They are broadly and fairly uniformly spread across the quadrant, indicating dips from $5^{\circ}-10^{\circ}$ to $90^{\circ}$. This pattern also is not indicative of uniform layer-parallel shear.

The foregoing analysis raises a question about the $1 / 4$ of the poles to cleavage (actually, 9 of the 32 poles) that are spread about the central part of the stereogram of the 53 unrotated beds (fig. $11 F$ ). The pattern indicates cleavage with $10^{\circ}-45^{\circ}$ dips. To determine if the nine poles spread about the central part of figure $11 F$ represent a previous compressional deformation event, I plotted the nine poles to cleavage in a separate diagram (fig. $11 H$ ). The diagram shows the nine poles, individually numbered, in both their unrotated (as recorded in the field) and rotated positions. It reveals that the nine poles are more widely dispersed after rotation than before rotation. Hence, they do not indicate a previous deformation.

The plot of poles to the rotated cleavage (fig. 11G) is interesting by comparison. The contour pattern for the poles to cleavage of the 53 unrotated beds (fig. $11 F$ ) is similar to the pattern for these same beds after rotation (fig. 11G), although clearly the poles to the rotated beds (fig. $11 G$ ) are more widely scattered. The rotated beds (fig. 11G) show only one fairly broad point maxima. But, unlike the unrotated poles to cleavage for the 53 poles (fig. $11 F$ ), which show two fairly close point maxima (one each for the anticline of the Bear Valley subsheet and the syncline of Basin Lake subsheet), the poles to cleavage of the rotated beds (fig. 11G) are not separated, but rather the poles of the two domains are mixed together! This is a second indication that the cleavage was not formed prior to folding.

The poles to cleavage for the two domains in diamictite, represented in figure $11 E$, are fairly narrowly confined-that is, they are not scattered far to the northwest or southeast beyond a narrow northeast-southwest zone. This indicates that the domains are not complicated by significant variations such as lateral ramps or tear faults. A few poles are for axial areas of folds where cleavage strike is about normal to the general northwest trend, but fold plunges are shallow; thus, poles fall within the narrow girdle shown in figure $11 E$. The belt possibly could have been even narrower; normal-slip along the Bear Valley fault may have caused the Bear Valley subsheet to have had a slight clockwise rotation, contributing to a broader distribution of poles than otherwise might have been the case. Still, the great circle azimuth and plunge for the 53-sample set in diamictite are very nearly the same as those determined for all cleavages recorded for the entire Poison Creek sheet (fig. 11A).

\section{Cleavage in Carbonate Strata of Footwall McDevitt Creek Sheet}

Cleavage in lower Paleozoic limestone and dolomite was recorded in the McDevitt Creek sheet, footwall of the Poison Creek thrust fault (fig. 11J). The data are from southern areas of the Poison Peak and Hayden Creek 7.5-minute quadrangles (fig. 2 ). The cleavage orientations are consistent with those of the Poison Creek sheet as a whole (compare fig. 11A and $J$ ) and of the Basin Lake subsheet (fig. 11D). Figure $11 \mathrm{~K}$, a subset of data from the Basin Lake subsheet, shows only poles for the coarse siltite unit of the Apple Creek Formation. Except for a small thrust slice of banded siltite unit of the Apple Creek, the coarse siltite unit makes up the northernmost exposures of Mesoproterozoic rocks of the subsheet (and of the Poison Creek sheet; fig. 4) and contains rocks that are in direct contact with carbonate strata of the McDevitt Creek sheet.

Carbonate rocks of the McDevitt Creek sheet are separately distinguished as limestone and dolomite in figure 11J. Poles to 
cleavage developed in limestone are more tightly confined than those formed in dolomite. In addition, poles just of the dolomite would depict a point maxima slightly to the north of that for limestone only, indicating somewhat steeper dips for cleavage in dolomite (fig. 11J). These observations may reflect several factors. (1) The two kinds of carbonate rocks behaved differently under the same stress conditions. The limestone tended to deform readily, forming a pervasive, continuous cleavage. The dolomite behaved in a brittle manner, forming a closely spaced cleavage (Tysdal, unpub. data, 1999). (2) Limestone occurs mainly in the eastern part of the McDevitt Creek sheet shown in figure 4, dolomite in the western part. The two areas may have experienced slightly different stress orientations during thrusting. The Poison Creek thrust fault makes a small change in orientation to a more westerly trend in the western part of the area of figure 4, which may reflect a slightly different stress orientation. This change in orientation is shown, for example, by the change in the axis of the Basin Lake syncline from a northwest trend in the eastern part of the Basin Lake subsheet (fig. 4) to a more westerly trend in the western part of the subsheet. However, the westerly orientation also is partly due to normal faulting in the western part of the study area.

\section{Age of Cleavage}

Coincident cleavages of the Proterozoic and Paleozoic strata of the study area are younger than the youngest affected Mississippian rocks. The orogenic compressional event that generated the cleavage is interpreted as Mesozoic, probably Cretaceous, and is based on regional data presented in a subsequent section, "Ages of Deformation." Data supporting a post-Mississippian age for development of cleavage are as follows. (1) Cleavage is directly related to the Poison Creek thrust fault and to the Hayden Creek and Basin Lake faults, which are interpreted as subsidiary thrusts that splay upward from the Poison Creek thrust fault. (2) Cleavage is most intensely developed along the faults and in the directly adjacent footwall of the subsidiary thrust faults. (3) Overturned beds along the Hayden Creek and Basin Lake faults consistently display cleavage dips that are less than bedding dips. This is unlikely to be the case if the cleavage is unrelated to the overturning. (4) Cleavage is axial planar to folds, which are related to the subsidiary faults. (5) I found only one continuous (pervasive) cleavage in the Proterozoic rocks of the Poison Creek sheet within the study area. In addition, cleavage measured in the carbonate strata of the footwall McDevitt Creek sheet displays an orientation pattern that is consistent with patterns in the Poison Creek sheet. The coarse siltite unit of the Mesoproterozoic Apple Creek Formation makes up a widespread unit of the Basin Lake subsheet, and it is in direct contact with the footwall Paleozoic carbonate rocks in the western part of the study area (fig. 4). The cleavage pattern for the coarse siltite unit is nearly identical to that of the subthrust carbonate strata. This clearly places the age of these coincident cleavages in the Phanerozoic. Some Proterozoic-age cleavage possibly may have formed (1) if the Proterozoic stress regime was about parallel to that of the Phanerozoic cleavage, or (2) if a Proterozoic cleavage formed during burial metamorphism, which would be parallel to bedding, or nearly so, and would have generated micas about parallel to bedding. In contrast to this study area, two cleavages, at high angles to one another, occur in Proterozoic rocks of the Poison Creek thrust sheet in the eastern part of the Salmon River Mountains, west of the study area (Tysdal, unpub. data, 1999). Reconnaissance study suggests that both cleavages there are of Phanerozoic age and formed during thrusting of the Poison Creek sheet over an oblique ramp in a section of the footwall.

\section{Extensional Deformation}

Normal faults that did not demonstrably develop along preexisting compressional faults are described and discussed in this section. No restoration to a pre-normal-slip position was undertaken for these faults.

\section{Lem Peak Normal Fault}

The Lem Peak fault trends northwest, similar to the other major structures of the study area. It commonly formed in the less competent siltite and metasandstone of the Lawson Creek Formation near the contact with the underlying competent orthoquartzite of the Swauger Formation. The fault dips south and underwent a large amount of displacement: about $12,000 \mathrm{~m}$ of slip is indicated by the stratigraphic separation shown in cross section $D-D^{\prime}$ of figure 6 . The dip of the fault is steep at the present depths of erosion, as shown in exposures of the juxtaposed rock units and by the three-dimensional patterns revealed across the differentially eroded mountainous terrain of the Lemhi Range. It is my interpretation that the Lem Peak normal fault curves and displays a lower inclination at a greater depth than that of the present exposures.

In plan view the Lem Peak fault displays a very irregular, jagged pattern marked by abrupt changes in direction of as much as $90^{\circ}$ (fig. 4). The pattern is reflected by juxtaposition of unrelated rock units and structures. For example, along the uppermost part of Hayden Creek a segment of the Lem Peak fault trends northeast, about parallel to the creek. Steeply dipping beds of the Big Creek Formation of the Hayden Creek sheet southeast of the Lem Peak fault display the same strike as steeply dipping beds of the Swauger Formation of the Lem Peak block northwest of the fault segment. A similar relationship exists between the headwaters of North Fork Cow Creek and Allison Creek. These corner areas display complex patterns of normal faults of limited extent. (See Tysdal and Moye, 1996; and Tysdal, 1996c, for map details that could not be shown in fig. 4.) In the Allison Creek-North Fork Cow Creek area, tight folds in the Swauger and overlying Lawson Creek Formations are not present in the Big Creek Formation on the opposite side of the fault. Further, axes of these folds have a westerly trend as opposed to the northwest trend common for most of the folds in strata north of the Lem Peak fault. 
Compressional structures occur in several areas of the Lem Peak block. The compressional structures probably are related to thrust faulting, but not related to juxtaposition of younger Swauger strata over older Big Creek rocks in the same area. Such an inferred fault may have been a higher structural level subsidiary thrust, similar in origin to the Hayden Creek or Bear Valley faults that formed within the Poison Creek anticline. In the Cow Creek-Allison Creek area (fig. 4), folds that formed prior to normal displacement on the Lem Peak fault lack corresponding folds in the adjacent rocks of the footwall. This lack of corresponding footwall folds suggests that the Lem Peak normal fault developed within a single subsheet.

One of the keys to normal-slip movement on the Lem Peak fault is the omission of strata along its trend. In the Hayden Creek subsheet, between the south half of the line of cross section $C-C^{\prime}$ and the Payne Creek fault (fig. 4), the preserved thickness of the Big Creek Formation increased markedly in both directions along strike. This is evident directly north of the head of Hayden Creek by the closeness of the Swauger Formation to the base of the fine siltite unit of the Apple Creek Formation in the southern part of the Bear Valley subsheet. Strata omitted from the thinned sequence of the Big Creek Formation are missing mainly due to normal-slip on both the Lem Peak and Hayden Creek faults. In the central segment of the Lem Peak fault, the dip of the Swauger of the Lem Peak block gradually increases from southwest to northeast and locally is overturned near the Lem Peak fault. These steeply dipping to overturned beds likely defined an anticline that was eroded or displaced during normal-slip.

When lateral offset is removed from the Payne Creek fault east of Wade Creek, the Lem Peak fault on the east side of the Payne Creek fault aligns with the segment farther west. Removal of the offset along the Payne Creek fault also facilitates interpretation of the Lem Peak fault from the junction of Hayden and Wade Creeks eastward to north of Mill Mountain, an area of sparse outcrops of Proterozoic strata. The Lem Peak fault must exist in the largely covered area because steeply dipping Swauger beds in the Mill Mountain area are on strike with steeply dipping Big Creek strata in the Cooper Creek drainagea structural discontinuity is needed to accommodate the lithologic change along trend of the strikes.

The arcuate-southward trace of the Lem Peak fault eastward from Wade Creek to the north side of Mill Mountain reflects the southward dip of the fault and the lesser elevation of the topography in this area. If the area were of near constant elevation, the steeply dipping Lem Peak normal fault would trend in a nearly straight line across the area (after removal of offset along the Payne Creek fault).

\section{Alder Creek Fault}

On the Basin Lake subsheet, north of the Bear Valley fault and southeast from Hayden Creek (fig. 4), the contact of the diamictite unit with the fine siltite unit of the Apple Creek Formation is interpreted as a fault along part of its length. From the east edge of the map area to near the Apple Creek fault, the contact is covered. Sheared strata of the fine siltite unit occur a short distance southeast from the Apple Creek fault, indicating movement along the steeply dipping contact for at least part of its southeastern extent, but there is no apparent angularity between strata of the two units. From the vicinity of Apple Creek westward to near Hayden Creek, the contact cuts across bedding.

\section{Faults with Compound Histories of Compressional and Extensional Movement}

Two faults discussed in this section are interpreted to have originated as compressional faults but to be expressed presently as normal faults. No restoration to a pre-normal-slip position was undertaken for these faults. (1) The Salmon River fault, in the western part of the map area, is interpreted as a tear fault that formed during differential movement within the Poison Creek sheet as it was transported to the northeast. During subsequent extensional movement, a segment of the fault was reactivated as the Lem Peak block was downdropped southwest of the Lem Peak normal fault. Later, the tear fault was reactivated again as part of the present through-going Salmon River normal fault.

(2) The Payne Creek fault trends north along Hayden Creek in the eastern part of the map area. It is interpreted as a tear fault that formed during compressional emplacement of the Poison Creek thrust sheet, similar to the Salmon River fault, but probably has undergone only one stage of subsequent extensional movement.

Both the Salmon River fault and the Payne Creek fault may have formed prior to thrusting, or may have exploited previously existing structural weaknesses. This possibility is suggested because of the contrasting styles and (or) the amount of fault displacement along different segments of these northerly trending faults or fault zones. No study was undertaken to evaluate this possibility. Data in hand do not suggest two episodes of compressional structures along the faults or fault zones. An extensional setting existed in the Cordilleran region during the Neoproterozoic and Early Cambrian, and evidence for it in eastcentral Idaho was summarized by Skipp and Link (1992) and Link and others (1993). Skipp and Link (1992) suggested that strata of these ages preserved in the central and southern parts of the Lemhi Range and Beaverhead Mountains were deposited in a north-trending rift basin. Neither these authors nor those cited by them presented evidence for northerly striking syn-rift faults that may have trended at a high angle to such a rift basin.

If the Payne Creek fault does have a Proterozoic history, then a third fault described in this section, the Apple Creek fault, possibly may share this history, because both faults lie along the same general trend. Hence, the Apple Creek fault is described in this section rather than in the section on extensional faulting.

\section{Salmon River Fault}

The Salmon River fault trends north across the western part of the study area and cuts the northwest-trending structural grain of the Lemhi Range at an angle of $60^{\circ}-90^{\circ}$ (fig. 4). It is 
interpreted as a tear fault formed during Mesozoic thrust faulting and folding of rocks of the Poison Creek sheet. West of the Salmon River fault, and north of the concealed segment of the Lem Peak normal fault in the southwest corner of the area of figure 4, Mesoproterozoic strata of the Apple Creek Formation are exposed in limited areas of outcrop. No Paleozoic or Mesozoic rocks are present. Rocks of the Eocene Challis Volcanic Group are widespread. All these strata are downdropped relative to rocks east of the Salmon River fault. Mesoproterozoic strata west of the Salmon River fault display north-trending strikes, contrasting with the northwest-trending strikes present in the Mesoproterozoic rocks east of the fault (fig. 4).

\section{Tear-Fault Movement}

The Mesozoic compressional development of the Salmon River fault of the study area fits Dahlstrom's (1970, p. 374-375) definition of a tear fault. He described a tear as a type of strikeslip fault that terminates both upwards and downwards against movement planes that may be detachments of thrust faults or low-angle normal faults. In thrusted strata, tears wholly within one thrust sheet or packet of thrust sheets can be either transverse or oblique to the regional trend. The Salmon River fault is oblique to the regional trend. Dahlstrom (1970) further noted that a tear fault wholly within a deformed sheet permits abrupt changes in the pattern of deformation on opposite sides of the tear through differential movement of adjacent component parts of the sheet. This is the case with the Salmon River fault, which served to compartmentalize the style of deformation that took place on opposite sides of it. Rocks east of the Salmon River fault, the main focus of this report, deformed into the major Poison Creek anticline and associated subsidiary thrusts of the Poison Creek sheet. Rocks directly west of the Salmon River fault in the map area were not so intensely deformed (fig. 4).

Structures in the Mesoproterozoic rocks east of the Salmon River fault display northwest strikes, in marked contrast to the north strike of the structures in the Mesoproterozoic rocks west of the fault (fig. 4). North strikes are to be expected for downthrown strata close to the Salmon River fault because they would have been reoriented toward parallelism with the fault as they were downdropped. For example, the north-striking syncline between Allison and McKim Creeks (fig. 4; fig. 5, west end of cross section $A-A^{\prime}$ ) is about parallel to the Salmon River fault and likely formed during downdropping of the rocks west of the fault. Dip of the fold limbs is moderate except for steep inclination of the east limb where it is upturned adjacent to the Salmon River fault. But north strikes are characteristic of all rocks west of the fault, not just those close to the fault. Further, the Apple Creek strata west of the fault generally display low dips, contrasting with the generally steep dips of strata east of the fault. These data suggest that the north strikes of Mesoproterozoic strata west of the fault were extant prior to being downthrown during extensional faulting. They may have formed during (compressional) tear faulting. Alternatively, the north-striking structures of the Salmon River fault zone may have an older origin, a possibility not evaluated here.

\section{Normal-Slip Movement Related to Emplacement of Lem Peak Block}

The Lem Peak block, delimited on its northeast side by the Lem Peak normal fault, is present on both sides of the Salmon River fault (figs. 3, 4). However, part of the block shows apparent left-lateral offset along the Salmon River fault. Understanding of this apparent lateral offset requires examination of segments of the Lem Peak fault. Mesoproterozoic strata west of the Salmon River fault are chiefly units of the Apple Creek Formation, except for the Mesoproterozoic Swauger Formation that crops out in the southwest corner of the map area (fig. 4). About $1 \mathrm{~km}$ directly west of the Swauger shown on the map, strata of the Big Creek Formation abut the Swauger on the south along a fault. This fault segment extends into the study area along the trace of $X-X^{\prime}$ (fig. 4), where it is concealed beneath volcanic rocks. $X-X^{\prime}$ is interpreted to be part of the Lem Peak normal fault because the rocks on opposite sides of this fault have the same stratigraphic-structural succession and relationships as in the Lemhi Range (Tysdal, 2000b).

Along the Salmon River fault, the Lem Peak fault and the associated stratigraphic units of the Lem Peak block display an apparent left-slip offset of as much as $8-10 \mathrm{~km}$ (fig. 4, offset is $X^{\prime}-X^{\prime \prime}$ ). (The apparent offset is not more precisely determined because, within the study area, the trace of the Lem Peak fault west of the Salmon River fault is entirely concealed by volcanic rocks.) Two possible interpretations are considered to accommodate the apparent left-slip offset on the Salmon River fault seen south of the Poison Creek fault. (1) The Swauger Formation east of the Salmon River fault and west of the Salmon River fault, in the southwest corner of the map area, behaved as one contiguous block. The block is delimited by the full length of the Lem Peak fault in the Lemhi Range, the concealed segment of the Lem Peak fault in the southwest corner of the map area, and by the Salmon River fault segment that connects these two parts of the Lem Peak fault (fig. 4, $X^{\prime \prime \prime}$ [and fault farther to east $\left.]-X^{\prime \prime}-X^{\prime}-X\right)$. In effect, the connecting part of the Salmon River fault is a segment of the Salmon River tear fault that was reactivated as a north-trending segment of the Lem Peak normal fault. This interpretation is favored here and is explained first (next paragraph). (2) A less likely interpretation attributes the apparent slip to mainly vertical movement along the Salmon River fault, and thus apparent left-lateral offset would be the result of dips of the flanking strata and of the Lem Peak fault. Such nearly vertical movement would have to be very large.

1. All Swauger strata south of the Lem Peak fault, on both sides of the Salmon River fault, were downdropped as one contiguous block. In this interpretation, the $X^{\prime}-X^{\prime \prime}$ segment of the Salmon River fault is a reactivated segment of the compressionally formed Salmon River tear fault. The tear fault zone of weakness was reactivated during downdropping of the Lem Peak block, and the block was broken into east and west parts along the $X^{\prime}-X^{\prime \prime}$ segment of the tear fault. The previously continuous nature of the block is shown by the sequence of strata and structural relationships that are preserved in both parts of the Lem Peak block. East of the $X^{\prime}-X^{\prime \prime}$ fault segment, in the eastern part of the Lem Peak block (that is, in the western part 
of the Lemhi Range), the south to north stratigraphic-structural succession is Swauger Formation-Lawson Creek FormationLem Peak normal fault (south-side-down)-Big Creek Formation-Apple Creek Formation. West of the $X^{\prime}-X^{\prime \prime}$ fault segment, in the western part of the Lem Peak block (that is, in the eastern part of the Salmon River Mountains), the similar stratigraphicstructural succession is Gunsight Formation-Swauger Formation-Lem Peak normal fault (south-side-down)-Big Creek Formation-Apple Creek Formation. Thus, in the Salmon River Mountains, the Lawson Creek Formation is cut out by the Lem Peak normal fault; only the lower part of the Swauger Formation is present and it is underlain by upper strata of the Gunsight Formation.

2. For vertical movement to account for the apparent leftslip offset of the Lem Peak fault and associated strata, the amount of apparent offset (fig. $4, X^{\prime}-X^{\prime \prime}$ ) is dependent on the magnitude of vertical displacement, the component of horizontal displacement (if any), and the dip of the Lem Peak fault. It is unlikely that, by itself, downdropping of strata and the contained Lem Peak fault west of the Salmon River fault could account for significant lateral displacement of the Lem Peak fault. First, assume no displacement on the Salmon River fault, and place a piercing point in the Lem Peak fault on opposite sides of the incipient Salmon River fault. Relative to the fixed piercing point on the east side of the Salmon River fault, the corresponding piercing point west of the fault would move south as strata west of the fault were downdropped. At the present depth of erosion, the Lem Peak fault is vertical or dips steeply southward.

Downdropping of strata west of the Salmon River fault as the sole explanation of the apparent lateral offset along the fault has another problem, related to the triangular wedge of Swauger of the Lemhi Range. The wedge lies east of the $X^{\prime}-X^{\prime \prime}$ segment of the Salmon River fault and southwest of the $X^{\prime \prime}-X^{\prime \prime \prime}$ segment of the Lem Peak fault (fig. 4). Middle Eocene volcanic rocks locally overlie the Lem Peak fault in the Lemhi Range, and the fault is assumed to have ceased movement before deposition of the volcanic rocks (Ruppel, 1980; Tysdal, 1996a). In contrast, the Salmon River fault offsets Eocene volcanic rocks and may still be active. Therefore, ignoring the triangular wedge of Swauger, the Apple Creek strata west of the Salmon River fault are downthrown relative to the Big Creek-Apple Creek sequence of the Lemhi Range northeast of the wedge of Swauger (fig. 4, $X^{\prime}-X^{\prime \prime}-X^{\prime \prime \prime}$ ). And, assuming the wedge of Swauger was faulted into place before down-on-the-west movement along the full length of the Salmon River fault (that is, along the segments north of $X^{\prime \prime}$ and south of $X^{\prime}$, as well as along the $X^{\prime}-X^{\prime \prime}$ segment), the Apple Creek west of the Salmon River fault actually is downthrown against the Swauger Formation east of the Salmon River fault_-even though the apparent relative displacement of the two formations is just the opposite. Thus, the map of figure 4 shows west-side-down along the full length of the fault. The relative up-down relationships change along the length of the Salmon River fault. In the northern part of the study area, the (actual) relationship is west-side-down. South of $X^{\prime \prime}$, the (apparent) relationship is east-side-down for the Proterozoic Apple Creek units west of the fault relative to the Swauger Formation east of the fault, but the (actual) relationship is west-side-down for the Tertiary Challis Volcanic Group rocks relative to the Swauger east of the fault (and the volcanic rocks are adjacent to and overlie the Apple Creek strata west of the fault).

\section{Normal-Slip Movement Related to Regional-Scale Salmon River Normal Fault}

The Salmon River normal fault extends across the entire map area (fig. 4). North of the map area, the fault extends along the western margin of the Lemhi Range (K.V. Evans, Falma Moye, and R.F. Hardyman, unpub. mapping, 1996) and likely continues farther north where it is concealed beneath the Lemhi River Valley east of Salmon (fig. 1), as shown on the mapping of Evans, K.I. Lund, and Tysdal (work in progress). South of the map area, the fault cuts the Challis Volcanic Group directly north of the Pahsimeroi River Valley (fig. 1), according to a general map of Janecke (1993, fig. 6; the name Allison Creek fault was used by Janecke for the fault).

The regional-scale normal displacement of the Salmon River normal fault developed subsequent to downdropping of the Lem Peak block. The apparent strike-slip displacement of the east and west parts of the Lem Peak block along the $X^{\prime}-X^{\prime \prime}$ segment of the Salmon River fault is confined to the area south of the Poison Creek thrust fault. This is shown by the lack of (or very minor) strike-slip offset of the footwall McDevitt Creek sheet along the Salmon River normal fault. Directly north of the map area (figs. 3, 4), the Poison Creek thrust fault and the subjacent Paleozoic carbonate rocks of the footwall McDevitt Creek sheet extend to the northwest beyond the map area. This continuation is concealed beneath unconsolidated sediments and volcanic rocks in the valley of the Salmon River, but the thrust fault and carbonate rocks crop out west of the valley (Ekren, 1988, pl. 2). The north-striking Salmon River fault crosses the northweststriking Poison Creek fault and the carbonate footwall rocks, but if these features are offset by lateral movement on the Salmon River fault, such offset is no more than about $1 \mathrm{~km}$. Any such offset would be right-slip, a direction opposite that of the apparent offset of rocks south of the Poison Creek fault.

\section{Payne Creek Cross Fault}

The Payne Creek fault trends north across the eastern part of the study area and cuts the Bear Valley subsheet and the Lem Peak block (figs. 3, 4). It dips steeply to the east, indicated by its eastward curving trace as the flanking topography decreases in elevation along the northern third of the fault (fig. 4). Proterozoic strata of the Bear Valley subsheet west of the Payne Creek fault show about $1.5 \mathrm{~km}$ of left-slip relative to strata east of the fault. The sequence east of the fault is from a greater depth in the hangingwall sequence than that west of the fault.

The origin of the Payne Creek fault is unclear, but it may have originated as a compressionally formed tear fault. The Payne Creek fault displays the following features in common with the Salmon River fault. (1) The north end of the Payne Creek fault does not offset footwall strata, but terminates at the 
subsidiary Bear Valley fault that floors the Bear Valley subsheet. (2) The fault is oriented at about $45^{\circ}$ to the transport direction of the host subsheet, thus is an oblique fault. (3) The strike is about north, subparallel to the Salmon River fault. (4) The southern extent of the Payne Creek fault, as far south as it has been mapped, offsets Swauger strata of the downdropped Lem Peak block. In contrast with the Salmon River fault, the Payne Creek fault does not serve to compartmentalize contrasting styles of deformation on opposite sides of it.

The following relationships are evident in the vicinity of the intersection of Wade and Hayden Creeks, where the Lem Peak block shows left-lateral offset along the Payne Creek fault. (1) In the vicinity of Wade Creek, the Payne Creek fault is marked by sheared orthoquartzite of the Mesoproterozoic Swauger Formation along its trend, although Ruppel (1980) did not map the fault in the Wade Creek area. (2) Beds directly adjacent to the fault have been rotated such that their strike is oriented at a small angle to the fault. A similar reorientation of bedding occurs about $5 \mathrm{~km}$ to the north along the fault. (3) Isolated outcrop areas of the Ordovician Kinnikinic Quartzite west of the fault (just south of the area of fig. 4) are much more closely aligned with Kinnikinic rocks east of the Payne Creek fault after removal of the offset of about $1.5 \mathrm{~km}$. Similarly, the segments of the Lem Peak fault (described previously) on opposite sides of the Payne Creek fault become aligned and form a continuous Lem Peak fault. But alignment of the two segments does not accommodate all of the offset of stratigraphic units farther north along the Payne Creek fault. For example, the Big Creek-Apple Creek contact west of the Payne Creek fault does not align with the same contact east of the fault. The misalignment remains unexplained; I suspect that some structural complications lie concealed beneath the large area of unconsolidated sediments between Cooper Creek and the Lem Peak fault (fig. 4).

The Payne Creek fault may have originated as a compressional tear within the Bear Valley subsheet during thrusting. Rocks east of the Payne Creek fault moved farther north relative to those west of the fault and exposed deeper levels of the stratigraphic succession. Subsequent to, or during, normal-fault emplacement of the Lem Peak block, the Payne Creek fault was reactivated and movement along it offset Swauger strata of the Lem Peak block. This interpretation assumes that the Payne Creek fault formed in a manner similar to the Salmon River normal fault. Alternatively, (1) the Payne Creek fault could predate normal faulting along both the Bear Valley and Lem Peak faults, with the Payne Creek fault reactivated south of the Lem Peak fault when the Lem Peak block was initially downdropped into its present position and (or) during later basin-and-range extensional activity. (2) The Payne Creek fault may predate thrusting, thus formed a structural weakness that subsequently was reactivated during both thrusting and extensional faulting.

\section{Apple Creek Fault}

The Apple Creek fault (east-central part of area, fig. 4) is concealed by landslide deposits and volcanic rocks. Its existence is necessary, however, to accommodate the contrast in thickness of the diamictite unit on opposite sides of the covered area. Strata northeast of the Alder Creek fault were downdropped during normal movement on the Alder Creek fault. The Apple Creek fault may be a tear fault, with normal displacement on its east side, that formed as a tear during the downdropping.

An alternative interpretation could consider the Apple Creek fault in the footwall of the Bear Valley fault to be the same structure as the Payne Creek fault of the hangingwall. Both faults display apparent left-slip offset. This connection is unlikely, however. (1) Directly south of the south end of the Apple Creek fault as shown in figure 4, the mutual contact of the Big Creek and Apple Creek Formations does not appear to be offset. The actual contact is not exposed, but no offset of the 1+ $\mathrm{km}$ magnitude evident directly to the north along the Apple Creek fault has taken place. (2) The footwall rocks of the Bear Valley fault would need to be shifted about $3 \mathrm{~km}$ to the northwest for the faults to be aligned. I have no evidence to suggest 3 $\mathrm{km}$ of right-slip along the Bear Valley fault. (3) West of the Apple Creek fault, the Alder Creek fault at the base of the diamictite unit truncates the fine siltite unit of the Apple Creek Formation with an angular relationship (Tietbohl, 1981; Tysdal, 1996a). If the Payne Creek and Apple Creek faults originally were one structure (a tear fault), the angular truncation of the fine siltite unit of the Apple Creek Formation also would have lain to the west of the Payne Creek fault. No counterpart of this cross-cutting fault segment occurs in the corresponding strata of the hangingwall. Further, west of the Apple Creek fault and north of the Bear Valley fault, the diamictite unit of the footwall contains a distinctive sequence of dark-gray magnetite-bearing beds. Directly south on the hangingwall, these distinctive beds were observed only near Hayden Creek and atop the ridge directly west of Hayden Creek. These data suggest that the hangingwall and the footwall have not undergone lateral shift relative to each other.

If the Payne Creek cross fault developed along a preexisting zone of structural weakness, a possibility raised at the beginning of this section, then it is appropriate to speculate that the Apple Creek fault could have developed along the same general preexisting zone. No direct evidence was obtained to evaluate this idea, however.

\section{Ages of Deformation}

\section{Compressional Deformation}

The maximum age of thrusting in the study area is indicated by the Paleozoic rocks of the footwall McDevitt Creek sheet. As discussed in the section on the age of cleavage, only one continuous (pervasive) cleavage was found in the hangingwall Mesoproterozoic rocks of the Poison Creek thrust sheet. Cleavage measured in the carbonate strata of the footwall McDevitt Creek sheet displays an orientation pattern that is consistent with patterns in the Poison Creek sheet. Nearly identical cleavage patterns are displayed by the footwall Paleozoic carbonate strata and the hangingwall Mesoproterozoic rocks near the trace of the Poison Creek thrust fault (fig. $11 J$ and $K$ ). This 
clearly places the age of these coincident cleavages in the Phanerozoic. The youngest Paleozoic strata known in the footwall of the Poison Creek thrust fault in the Lemhi Range are of the Upper Devonian Jefferson Formation (Anderson, 1961). East of the map area, in the Beaverhead Mountains northeast of Leadore, Idaho (fig. 1), strata as young as Triassic age underwent compressional deformation during thrusting associated with the Hawley Creek fault (Lucchitta, 1966; K.I. Lund, oral commun., 2000), which I interpret as corresponding to subsidiary thrust faults in the footwall of the Poison Creek thrust fault.

The minimum age of thrusting in the Lemhi Range is provided by igneous rocks. Several undeformed granitic stocks in the central part of the Lemhi Range clearly are younger than the thrust faulting and were intruded and partly exposed by erosion before eruption of the Challis Volcanic Group (Ruppel, 1978, p. 14; Tysdal, 1996b). The Big Eight Mile pluton, mapped by Ruppel (1980) about $50 \mathrm{~km}$ southeast of this study area, postdates thrust faulting (Ruppel, 1980). The Big Eight Mile pluton contains biotite that yielded a potassium-argon date of $49.4 \pm 1.7$ Ma (Ruppel and Lopez, 1988, p. 72) (50.6 $\pm 1.7 \mathrm{Ma}$, adjusted for currently accepted decay constants; J.D. Obradovich, oral commun., 1993). [Apparently, Ruppel (1978, p. 14) mistakenly applied this date to a dike related to another pluton, but correctly attributed the date in Ruppel and Lopez (1988).]

A granitic pluton is inferred to lie beneath a magnetic anomaly in the headwaters area of the North Fork McKim Creek (fig. 4). The anomaly is one of several that lie along a northwest trend within the general region (Zietz and others, 1978; Webring and Mabey, 1995; pl. 2 in Worl and others, 1989); it is similar to the anomaly over the exposed Big Eight Mile pluton. A metamorphic aureole and associated silicified rock characterize the northern part of the McKim Creek anomaly. The metamorphosed and silicified rocks extend across structures in the map area. Silicified and tourmaline-bearing rocks replace sheared rock along parts of the Hayden Creek and Bear Valley faults, postdating movement on these faults.

In the Beaverhead Mountains, about $20 \mathrm{~km}$ north-northeast of Salmon (fig. 1), compressionally deformed Proterozoic strata and a compressional fault are intruded by the Carmen Creek pluton (map of Ruppel and others, 1993; K.V. Evans, oral commun., 1999; personal observation). Using ${ }^{40} \mathrm{Ar} /{ }^{39} \mathrm{Ar}$ dating, Kilroy and Sutter (1984) determined that a quartz diorite phase of the pluton yielded a Late Cretaceous date of $80.9 \pm 1.9 \mathrm{Ma}$; a more mafic phase of the intrusive is considered to be equivalent in age, or older. A granodiorite phase yielded middle Eocene dates. Although the pluton is not in the Lemhi Range, it lies farther northeast than the Lemhi Range, and, if deformation generally progressed eastward with time, as is the general situation in the Rocky Mountain thrust belt, then thrusting in the Lemhi Range may have ceased prior to intrusion of the Carmen Creek pluton.

\section{Extensional Deformation}

Challis volcanic rocks postdate normal-slip movement on faults at least locally. South and west of Mill Mountain, in the vicinity of Wade Creek (fig. 4), a segment of the Lem Peak fault is locally concealed by rocks of an unknown unit of the Eocene Challis Volcanic Group. Other rocks of the Challis Volcanic Group were deposited across the Bear Valley fault west of Hayden Creek after normal displacement took place on the fault, as shown north of the head of Bear Valley Creek in figure 4 and cross section $B-B^{\prime}$ (fig. 5).

The tuff of Ellis Creek (McIntyre and others, 1982; Fisher and others, 1992), a unit of the Challis Volcanic Group, overlies the Poison Creek thrust fault at the head of Poison Creek (fig. 4) and locally in the western part of the Allison Creek quadrangle (fig. 2; Tysdal and Moye, 1996). Biotite from tuff of this unit about $45 \mathrm{~km}$ directly west of the Poison Creek occurrence yielded a middle Eocene potassium-argon date of $48.4 \pm 1.6 \mathrm{Ma}$ (Fisher and Johnson, 1995; Fisher and others, 1992). Movement on the Poison Creek thrust fault had ceased by the time of deposition of the tuff.

\section{Evaluation of Possible Proterozoic Compressional Deformation}

Compressional deformation of Mesoproterozoic age has been reported for local areas of the central Idaho region. Radiometric dating of coarse-grained granitic plutons in the Salmon River Mountains yielded Mesoproterozoic dates (Evans, 1986; Evans and Zartman, 1990). One of the plutons, about $8 \mathrm{~km}$ northwest of Salmon, crosscuts folds formed in the Mesoproterozoic host strata (Brown, 1973; Evans, 1981, 1986; Lopez, 1981). Further, regional biotite-grade metamorphism of the host strata occurred prior to intrusion of the pluton. Contact metamorphic aureoles around the Proterozoic plutons overprint the regional metamorphic assemblage of the country rocks (Evans and Zartman, 1990).

Only one compressional deformation was recognized in the study area of the Lemhi Range, and it probably is Late Cretaceous. If an unrecognized Proterozoic compressional deformation took place as well, cleavage that may have been generated during the deformation could have been coincident, or nearly so, with that of the Cretaceous event, thus was not distinguished from the Cretaceous cleavage.

\section{Reevaluation of Medicine Lodge Thrust System and Hayden Creek Window}

The foregoing presentation and interpretation of structural features set the stage for a reevaluation of the concept of the Medicine Lodge thrust fault and its associated features in the western part of the Lemhi Range.

A Medicine Lodge thrust fault was first mapped in the Beaverhead Mountains east of Leadore, Idaho (fig. 1) by Kirkham (1927). Other workers later mapped more thrust faults northwestward in the Beaverhead Mountains and in nearby southwestern Montana. Ruppel (1978) introduced the name "Medicine Lodge thrust system" for the assemblage of these faults and extended the system to include faults that he had mapped in the Lemhi Range. 
Within the Lemhi Range, Ruppel (1978) initially treated the "thrust system" as a single megathrust fault. Later, Ruppel and Lopez (1984, p. 1) characterized the Medicine Lodge thrust plate as a unique assemblage of rocks hosting a "network of interrelated flat thrust faults that both bound and cut the thrust plate***and dip into a basal decollement zone that forms the lowermost part of the plate." Thrust faults of the plate also were described as "interlaced" imbricates. The basal zone was characterized as 50-300 m of intensely sheared, crushed, brecciated, and mylonitized rocks grading upward into less internally sheared but complexly folded and faulted rocks of the plate (Ruppel, 1978, p. 8; Ruppel and Lopez, 1984). Ruppel (1978) and Ruppel and Lopez $(1984,1988)$ envisioned the Medicine Lodge thrust as separating allochthonous rocks of the Mesoproterozoic Lemhi Group and younger strata from subjacent, autochthonous, older Mesoproterozoic rocks of the Yellowjacket Formation. These workers interpreted the Yellowjacket as autochthonous because they considered its strata generally to be only slightly deformed or to exhibit a style of deformation different from strata of the Lemhi Group and younger rocks designated as allochthonous. These interpreted differences in deformation led them to "suggest that the Yellowjacket has not been tectonically transported by thrusting like the overriding, intricately folded and faulted rocks in the Medicine Lodge plate" (Ruppel and Lopez, 1984, p. 23). Ruppel (1978, p. 8) stated that one of the best exposures of the Medicine Lodge fault system is in the Lemhi Range north of Mill Mountain, within the southeastern part of the study area of this report, where a window (the Hayden Creek window) resulted from erosion through the Medicine Lodge thrust plate.

My mapping in this area in the northern part of the Lemhi Range (Tysdal, 1996a, 1996b, 1996c) leads me to conclude that the Medicine Lodge thrust plate does not exist in this part of the range, that no window was eroded through such a thrust plate, and that rocks assigned (by Ruppel and Lopez, 1988) to the Yellowjacket Formation in the northern part of the Lemhi Range (1) belong to another formation and (2) are as intensely deformed as rocks of other Mesoproterozoic formations. My mapping extends for $8 \mathrm{~km}$ east and $18 \mathrm{~km}$ west of their Hayden Creek window (hereafter called "window"; location of "window" shown in fig. 4) and reveals three northwest-trending faults that cross it: from north to south, the Poison Peak, Bear Valley, and Hayden Creek faults. Stratigraphic units present between any pair of these northwest-trending faults also occur on strike on both sides of the "window." Where not covered by Cenozoic strata, the Proterozoic units are contiguous across the "window" as well.

The Hayden Creek "window" measures approximately $6 \times 20 \mathrm{~km}$ (fig. 4). The outline is taken mainly from plate 1 of Ruppel and Lopez (1984), modified slightly to accommodate the distribution of "Yellowjacket" rocks shown on the geologic map of the Patterson 15-minute quadrangle mapped by Ruppel (1980). Strata east of Hayden Creek, and north of the Alder Creek fault, were assigned to the "Yellowjacket" Formation by Ruppel and Lopez (1984) and considered to be part of the autochthon (fig. 4). Other than the Hayden Creek "window," the remainder of the pre-thrusting rocks (that is, older than the Eocene Challis Volcanic Group) of the map area were assigned to the allochthonous Medicine Lodge thrust plate by these authors.

Directly west of Wade Creek (fig. 4), at the western margin of the Patterson quadrangle mapped by Ruppel (1980), a $200 \mathrm{~m}$ long fault within an island of rock surrounded by glacial deposits was interpreted as the southern limit of the "window." Ruppel and Lopez (1988, p. 76) concluded that this fault delimited the sole of the Medicine Lodge thrust plate. Ruppel and Lopez (1984) showed this island of rock as steeply inclined, slightly overturned Swauger Formation on the south abutting "Yellowjacket" strata on the north; the entire Lemhi Group is absent. In figure 4, the island of rock is shown as a small lens-shaped area adjacent to the Lem Peak normal fault and less than $1 \mathrm{~km}$ west of the Payne Creek fault. The entire Lemhi Group (table 1) is not missing from this area as believed. Strata of the lens-shaped area shown as "Yellowjacket" on the map of Ruppel (1980) are Big Creek Formation. Nevertheless, most of the Lemhi Group is missing, not due to the existence of a "window," but due to a large amount of normal displacement (down to the southwest) on the Lem Peak normal fault and a comparatively small amount on the Hayden Creek fault as well (Tysdal, 1996a, 1996b, 1996c).

Rocks in the area of the southeast edge of the Hayden Creek "window," on the ridge directly east of the southern reaches of Cooper Creek, were described as sheared and brecciated Big Creek Formation in thrust contact above the "Yellowjacket" (Ruppel, 1980; Ruppel and Lopez, 1988, p. 76). I found no evidence of a (sole) thrust fault in this area. Proterozoic rocks of the Big Creek Formation lie above and below the depicted sole-fault, although good outcrops are scarce. No rocks in outcrop or float are sheared; outcrops of the finegrained rock exhibit cleavage that dips about $30^{\circ} \mathrm{SW}$., a common inclination for rocks in the general region. This southern part of the "window" lies between the Bear Valley and Hayden Creek faults (fig. 4). The Big Creek and Apple Creek strata between these faults are continuous from west of the "window," through it, and on east beyond the limit of figure 4. These data show that the "window" does not exist.

About $6 \mathrm{~km}$ north of Mill Mountain, near the Alder Creek fault (fig. 4), the Big Creek Formation was interpreted as thrust over turbidites and debris flows of the "Yellowjacket" (Ruppel, 1980; Ruppel and Lopez, 1984, pl. 1; 1988, p. 76). The solethrust fault depicted on the map of Ruppel (1980) is at the horizon that I have locally mapped as the contact of the fine siltite unit and the diamictite unit of the Apple Creek Formation. Their fault extended northward on plate 1 of Ruppel and Lopez (1984) and clearly trends across the northwest structural grain of the rocks of the region and cuts across the rock units that Tietbohl (1981, 1986) and Tysdal (1996b) mapped in the area (fig. 4). The Medicine Lodge thrust fault of Ruppel (1980) and Ruppel and Lopez (1984) clearly would have to cut across beds that are steep to vertical and are continuous above and below their flat "fault." No horizontal or shallowly dipping structural surface cuts across their "autochthonous Yellowjacket" rock units north of the Alder Creek fault ("autochthon" boundary shown in fig. 4). Further, a 3-4 km wide area of upper plate rocks of the Medicine Lodge plate was mapped previously between the "autochthonous" strata to the east and the Hayden 
Creek "window" (Ruppel and Lopez, 1984, pl. 1). However, the same Apple Creek strata (fig. 4, units Yad and Yac) continue along strike from the east edge of the area to the west side of Hayden Creek where they are shown by Ruppel and Lopez (1984, pl. 1) as part of the "authochthon" and as allochthonous rocks of the Medicine Lodge thrust plate that lie east of the Hayden Creek "window."

The Alder Creek fault is interpreted to exist along the contact of the fine siltite unit with the overlying diamictite unit of the Apple Creek Formation (Tysdal, 1996a). The amount of displacement on this fault, which is largely covered, is unknown but is considered to be minor. Along the fault, at the very east edge of the area covered by figure 4, Ruppel (1980) reported an area of breccia in rocks mapped as "Yellowjacket" (that is, within the fine siltite unit of the Apple Creek Formation) in the Alder Creek drainage. Ruppel and Lopez (1984) interpreted the breccia to be tectonic in origin and to have developed in the sole zone of the Medicine Lodge thrust plate. I do not believe the breccia to be of tectonic origin. It is hydraulically fractured (and hydrothermally altered), but little to no offset is evident across fractures that define the breccia fragments. In any case, the Alder Creek fault is steep to vertical and is not a flat thrust as Ruppel and Lopez $(1984,1988)$ described it.

Stretched, intensely brecciated, and mylonitized rocks were reported to constitute the sole zone of the Medicine Lodge thrust sheet in the Hayden Creek area (Ruppel, 1978, p. 8; and Ruppel and Lopez, 1984, 1988). No mylonite or intensely brecciated rocks were found in this area by me or reported by Tietbohl (1981, 1986). The diamictite unit is intensely cleaved, however. The cleavage reflects a high ductility that is due to a high content of clay and silt, and strong cleavage near Hayden Creek is due to location of the diamictite in the footwall of the Bear Valley fault, which dips about $30^{\circ} \mathrm{SW}$. The fault is not a horizontal (flat) thrust of the sole zone of a decollement at the base of a (Medicine Lodge) thrust sheet of Ruppel (1978).

\section{Conclusions}

The following are major conclusions resulting from mapping and structural studies in the western part of the Lemhi Range.

1. Most of the study area lies within the hangingwall of the Poison Creek thrust sheet.

2. The thrust has a stratigraphic separation of $10,500+\mathrm{m}$ and an unknown amount of transport to the northeast.

3. The Poison Creek thrust sheet comprises three subsheets separated, from northeast to southwest, by the Bear Valley and Hayden Creek faults, which presently display normal displacement. The Hayden Creek fault also displays thrust displacement, and both faults likely originated as minor thrusts.

4. Removal of normal-slip displacement on the Bear Valley, Hayden Creek, and lesser faults within the subsheets to pre-normal-slip positions revealed that the thrust sheet makes up the leading part of a large anticline. Amplitude of the anticline exceeds $12,000 \mathrm{~m}$.

5. Cleavage and bedding in the hangingwall and footwall of the thrust record only one compressional deformation event.
The deformation is younger than cleaved Mississippian rocks of the footwall in the study area, and based on regional data, it is younger than deformed Triassic strata: deformation likely is of Late Cretaceous age.

6. Compressional deformation ceased prior to extrusion of the tuff of Ellis Creek, a unit of the middle Eocene Challis Volcanic Group, and prior to intrusion of Eocene granitic plutons. The deformation likely occurred prior to emplacement of the Late Cretaceous Carmen Creek pluton, present in the Beaverhead Mountains to the northeast of the Lemhi Range.

7. Significant extensional deformation took place prior to extrusion of the Eocene Challis Volcanic Group.

8. The Medicine Lodge thrust system, a single regionally extensive thrust sheet previously interpreted to extend across east-central Idaho and into southwestern Montana, does not exist within the study area, nor does the Hayden Creek window that was interpreted to have been eroded through it.

\section{References Cited}

Anderson, A.L., 1961, Geology and mineral resources of the Lemhi quadrangle, Lemhi County: Idaho Bureau of Mines and Geology Pamphlet 124, $111 \mathrm{p}$.

Brown, D.C., 1973, Fold geometry in the Belt sequence, Salmon, Idaho: Lancaster, Pa., Franklin and Marshall College M.S. thesis, $71 \mathrm{p}$.

Dahlstrom, C.D.A., 1970, Structural geology in the eastern margin of the Canadian Rocky Mountains: Bulletin of Canadian Petroleum Geology, v. 18, p. 332-406.

Ekren, E.B., 1988, Stratigraphic and structural relations of the Hoodoo Quartzite and Yellowjacket Formation of Middle Proterozoic age from Hoodoo Creek eastward to Mount Taylor, central Idaho: U.S. Geological Survey Bulletin 1570, 17 p.

Evans, K.V., 1981, Geology and geochronology of the eastern Salmon River Mountains, Idaho, and implications for regional Precambrian tectonics: University Park, Pa., Pennsylvania State University Ph. D. dissertation, $222 \mathrm{p}$.

Evans, K.V., 1986, Middle Proterozoic deformation and plutonism in Idaho, Montana, and British Columbia, in Roberts, S.M., ed., Belt Supergroup-A guide to Proterozoic rocks of western Montana and adjacent areas: Montana Bureau of Mines and Geology Special Publication 94, p. 237-244.

Evans, K.V., 1999, The Yellowjacket Formation of east-central Idaho, in Berg, R.B., ed., Proceedings-Belt symposium III: Montana Bureau of Mines and Geology Special Publication 112, p. 17-30.

Evans, K.V., and Zartman, R.E., 1990, U-Th-Pb and Rb-Sr geochronology of Middle Proterozoic granite and augen gneiss, Salmon River Mountains, east-central Idaho: Geological Society of America Bulletin, v. 102, p. 63-73.

Fisher, F.S., and Johnson, K.M., 1995, Challis volcanic terrane, in Fisher, F.S., and Johnson, K.M., eds., Geology and mineral-resource assessment of the Challis $1^{\circ} \times 2^{\circ}$ quadrangle, Idaho: U.S. Geological Survey Professional Paper 1525, p. 41-43.

Fisher, F.S., McIntyre, D.H., and Johnson, K.M., 1992, Geologic map of the Challis $1^{\circ} \times 2^{\circ}$ quadrangle, Idaho: U.S. Geological Survey Miscellaneous Investigations Series Map I-1819, 39 p., 1 sheet, scale 1:250,000. 
Harrison, J.E., and Cressman, E.R., 1993, Geology of the Libby thrust belt of northwestern Montana and its implications to regional tectonics: U.S. Geological Survey Professional Paper 1524, 42 p.

Jamison, W.R., 1992, Stress controls on fold thrust style, in McClay, K.R., ed., Thrust tectonics: New York, Chapman and Hall, Inc., p. 155-164.

Janecke, S.U., 1993, Structures in segment boundary zones of the Lost River and Lemhi faults, east central Idaho: Journal of Geophysical Research, v. 98, no. B9, p. 16223-16238.

Janecke, S.U., VanDenburg, C.J., Blankenau, H.J., and M'Gonigle, J.W., 2000, Long-distance longitudinal transport of gravel across the Cordilleran thrust belt of Montana and Idaho: Geology, v. 28, p. $439-442$.

Kilroy, K.C., and Sutter, J.F., $1984,{ }^{40} \mathrm{Ar} /{ }^{39} \mathrm{Ar}$ geochronology and structural relationships of some intermediate intrusions in the northern Beaverhead Mountains, Idaho-Montana: Geological Society of America Abstracts with Programs, v. 16, no. 4, p. 226.

Kirkham, V.R.D., 1927, A geologic reconnaissance of Clark, Jefferson, and parts of Butte, Custer, Fremont, Lemhi, and Madison Counties, Idaho: Idaho Bureau of Mines and Geology Pamphlet 19, 47 p.

Link, P.K.,Christie-Blick, Nicholas, Stewart, J.H., Miller, J.M.G., Devlin, W.J., and Levy, M., 1993, Late Proterozoic strata of the United States Cordillera, in Link, P.K., and others, Middle and Late Proterozoic stratified rocks of the western U.S. Cordillera, Colorado Plateau, and Basin and Range province: Boulder, Colo., Geological Society of America, The Geology of North America, v. C-2, Chapter 6, p. 536-558.

Lopez, D.A., 1981, Stratigraphy of the Yellowjacket Formation of eastcentral Idaho: U.S. Geological Survey Open-File Report 81-1088, $218 \mathrm{p}$.

Lucchitta, B.K., 1966, Structure of the Hawley Creek area, IdahoMontana: University Park, Pa., Pennsylvanian State University Ph. D. dissertation, $235 \mathrm{p}$.

McIntyre, D.H., Ekren, E.B., and Hardyman, R.F., 1982, Stratigraphic and structural framework of the Challis volcanics in the eastern half of the Challis $1^{\circ} \times 2^{\circ}$ quadrangle, Idaho, in Bonnichsen, Bill, and Breckenridge, R.M., eds., Cenozoic geology of Idaho: Idaho Bureau of Mines and Geology Bulletin 26, p. 3-22.

McNaught, M.A., and Mitra, Gautam, 1993, A kinematic model for the origin of synclines: Journal of Structural Geology, v. 15, p. 805-808.

Mitra, Gautam, and Elliott, David, 1980, Deformation of basement in the Blue Ridge and the development of the South Mountain window, in Wones, D.R., ed., Caledonides in the U.S.A., proceedings of International Geological Congress project 27: Blacksburg, Va., Virginia Polytechnic Institute and State University Memoir 2, p. 307-311.

Mitra, Shankar, 1990, Fault-propagation folds-Geometry, kinematic evolution, and hydrocarbon traps: American Association of Petroleum Geologists Bulletin, v. 74, p. 921-945.

Plumb, K.A., 1991, New Precambrian time scale: Episodes, v. 14, no. 2, p. 139-140.

Ross, C.P., 1934, Geology and ore deposits of the Casto quadrangle, Idaho: U.S. Geological Survey Bulletin 854, $135 \mathrm{p}$.

Ruppel, E.T., 1968, Geologic map of the Leadore quadrangle, Lemhi County, Idaho: U.S. Geological Survey Geologic Quadrangle Map GQ-733, scale 1:62,500.

Ruppel, E.T., 1975, Precambrian Y sedimentary rocks in east-central Idaho: U.S. Geological Survey Professional Paper 889-A, 23 p.
Ruppel, E.T., 1978, Medicine Lodge thrust system, east-central Idaho and southwest Montana: U.S. Geological Survey Professional Paper $1031,23 \mathrm{p}$.

Ruppel, E.T.,1980, Geologic map of the Patterson quadrangle, Lemhi County, Idaho: U.S. Geological Survey Geologic Quadrangle Map GQ-1529, scale 1:62,500.

Ruppel, E.T.,1993, Cenozoic tectonic evolution of southwest Montana and east-central Idaho: Montana Bureau of Mines and Geology Memoir 65, $62 \mathrm{p}$.

Ruppel, E.T., and Lopez, D.A., 1981, Geologic map of the Gilmore quadrangle, Lemhi County, Idaho: U.S. Geological Survey Geologic Quadrangle Map G0-1543, scale 1:62,500.

Ruppel, E.T., and Lopez, D.A., 1984, The thrust belt in southwest Montana and east-central Idaho: U.S. Geological Survey Professional Paper $1278,41 \mathrm{p}$.

Ruppel, E.T., and Lopez, D.A., 1988, Regional geology and mineral deposits in and near the central part of the Lemhi Range, Lemhi County, Idaho: U.S. Geological Survey Professional Paper 1480, $122 \mathrm{p}$.

Ruppel, E.T., O'Neill, J.M., and Lopez, D.A., 1993, Geologic map of the Dillon $1^{\circ} \times 2^{\circ}$ quadrangle, Idaho and Montana: U.S. Geological Survey Miscellaneous Investigations Series Map I-1803-H, scale $1: 250,000$.

Skipp, Betty, 1987, Basement thrust sheets in the Clearwater orogenic zone, central Idaho and western Montana: Geology, v. 15, p. 220224.

Skipp, Betty, 1988, Cordilleran thrust belt and faulted foreland in the Beaverhead Mountains, Idaho and Montana, in Schmidt, C.J., and Perry, W.J., Jr., eds., Interaction of the Rocky Mountain foreland and the Cordilleran thrust belt: Geological Society of America Memoir 171, p. 237-266.

Skipp, Betty, and Link, P.K., 1992, Middle and Late Proterozoic rocks and Late Proterozoic tectonics in the southern Beaverhead Mountains, Idaho and Montana-A preliminary report, in Link, P.K., Kuntz, M.A., and Platt, L.B., eds., Regional geology of eastern Idaho and western Wyoming: Geological Society of America Memoir 179, p. 141-154.

Soregaroli, A.E., 1961, Geology of the McKim Creek area, Lemhi County, Idaho: Moscow, Idaho, University of Idaho M.S. thesis, 53 p.

Suppe, John, 1983, Some theory of parallel folding useful in predicting subsurface structure: Princeton, N.J., Princeton University Department of Geological and Geophysical Sciences, and Taiwan Petroleum Exploration Division of Chinese Petroleum Corporation, p. 1-11.

Suppe, John, 1985, Principles of structural geology: Englewood Cliffs, N.J., Prentice-Hall, 537 p.

Suppe, John, and Medwedeff, D.A., 1990, Geometry and kinematics of fault-propagation folding: Eclogae Geologicae Helvetiae, v. 83, p. 409-454.

Tietbohl, D.R., 1981, Structure and stratigraphy of the Hayden Creek area, Lemhi Range, east-central Idaho: University Park, Pa., Pennsylvania State University M.S. thesis, 121 p.

Tietbohl, D.R., 1986, Middle Proterozoic diamictite beds in the Lemhi Range, east-central Idaho, in Roberts, S.M., ed., Belt SupergroupA guide to Proterozoic rocks of western Montana and adjacent areas: Montana Bureau of Mines and Geology Special Publication 94, p. 197-207.

Tysdal, R.G., 1996a, Geologic map of adjacent areas of the Hayden Creek and Mogg Mountain quadrangles, Lemhi County, Idaho: U.S. 
Geological Survey Miscellaneous Investigations Series Map I-2563, scale $1: 24,000$.

Tysdal, R.G., 1996b, Geologic map of the Lem Peak quadrangle, Lemhi County, Idaho: U.S. Geological Survey Geologic Quadrangle GQ1777 , scale $1: 24,000$.

Tysdal, R.G., 1996c, Geologic map of part of the May Mountain quadrangle, Lemhi County, Idaho: U.S. Geological Survey Open-File Report 96-537, scale 1:24,000.

Tysdal, R.G., 2000a, Stratigraphy and sedimentology of Middle Proterozoic rocks in northern part of Lemhi Range, Lemhi County, Idaho: U.S. Geological Survey Professional Paper 1600, 40 p.

Tysdal, R.G., 2000b, Revision of Middle Proterozoic Yellowjacket Formation of central Idaho: U.S. Geological Survey Professional Paper 1601-A, $13 \mathrm{p}$.
Tysdal, R.G., and Moye, Falma, 1996, Geologic map of the Allison Creek quadrangle, Lemhi County, Idaho: U.S. Geological Survey Geologic Quadrangle Map GQ-1778, scale 1:24,000.

Webring, M.W., and Mabey, D.R., 1995, Geophysical anomalies, in Fisher, F.S., and Johnson, K.M., Geology and mineral-resource assessment of the Challis $1^{\circ} \times 2^{\circ}$ quadrangle, Idaho: U.S. Geological Survey Professional Paper 1525, p. 53-62.

Worl, R.G., Wilson, A.B., Smith, C.L., Kleinkopf, M.D., and Sykes, R.C., 1989, Mineral resource potential and geology of the Challis National Forest, Idaho: U.S. Geological Survey Bulletin 1873, $101 \mathrm{p}$.

Zietz, Isidore, Gilbert, F.P., and Kirby, J.R., Jr., 1978, Aeromagnetic map of Idaho; color coded intensities: U.S. Geological Survey Geophysical Investigations Map GP-920, scale 1:1,000,000.

Published in the Central Region, Denver, Colorado

Manuscript approved for publication November 28, 2001

Graphics by author and Gayle M. Dumonceaux

Photocomposition by Gayle M. Dumonceaux

Edited by L.M. Carter 